\title{
UNDERSTANDING A CONSUMER'S PATH TO PURCHASE JEANS IN A SOCIAL MEDIA CONTEXT
}

\author{
By \\ Shanghavy Karunakaran \\ BComm, Ryerson University, 2016
}

\author{
A thesis \\ presented to Ryerson University \\ in partial fulfillment of the \\ requirements for the degree of \\ Master of Science in Management \\ in the program of \\ Master of Science in Management (MScM)
}

Toronto, Ontario, Canada, 2019

@Shanghavy Karunakaran, 2019 


\section{AUTHOR'S DECLARATION}

I hereby declare that I am the sole author of this thesis. This is a true copy of the thesis, including any required final revisions, as accepted by my examiners.

I authorize Ryerson University to lend this thesis to other institutions or individuals for the purpose of scholarly research.

I further authorize Ryerson University to reproduce this thesis by photocopying or by other means, in total or in part, at the request of other institutions or individuals for the purpose of scholarly research.

I understand that my thesis may be made electronically available to the public. 


\title{
UNDERSTANDING A CONSUMER'S PATH TO PURCHASE JEANS IN A SOCIAL MEDIA CONTEXT \\ Shanghavy Karunakaran \\ Master of Science in Management \\ Ted Rogers School of Management \\ Ryerson University, 2019
}

\begin{abstract}
Consumers are increasingly depending on online and social platforms to find product and brand information while fashion brands seek to further engage with consumers online. This study proposes a five-construct structural model to measure the influence of product involvement, fashion brand involvement, altruistic involvement, and online brand engagement on purchase intention in a social media context. Through partial least squares structural equation modeling (PLS-SEM), a sample of 799 shoppers in North America were empirically tested to validate the findings drawn from the model. From the six hypotheses presented, all were accepted; including three hypotheses which were an extension of previous research. The findings confirm a consumer's journey is prevalent and future testing of the model in new applications will help to enhance and progress social media studies around involvement and engagement.
\end{abstract}

Keywords: Social Media, Product Involvement, Fashion Brand Involvement, Altruistic Involvement, Online Brand Engagement, Purchase Intention, PLS-SEM 


\section{Acknowledgements}

I would like to express my sincere gratitude to my supervisor, Dr. Donna Smith, for her guidance, availability, patience, and encouragement throughout my journey in academic writing.

I would also like to express my sincere gratitude to my committee members, Dr. Hong Yu, Professor Osmud Rahman, Dr. Jenna Jacobson, as well as all the colleagues, mentors and professors at Ryerson University for their support and guidance in my academic career.

I am also sincerely grateful to my dear friends and family, as well as Leo, Madiha, and Janarthan who have continually provided encouragement and academic peer support throughout these years.

Finally, thank you to my wonderful mother Kavusala, for your strength, patience, support, unconditional love, and encouragement throughout these years. Because of your sacrifices I can receive higher education, and I am so fortunate to experience that. Thank you for everything you do for us. 


\section{Table of Contents}

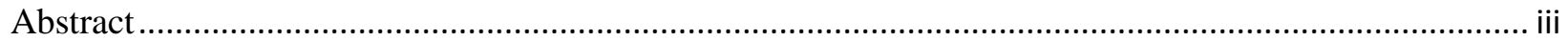

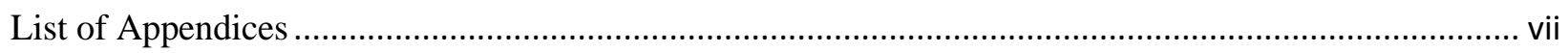

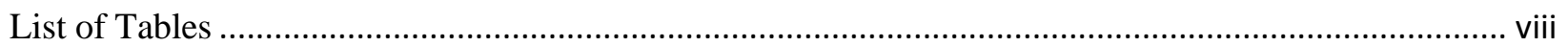

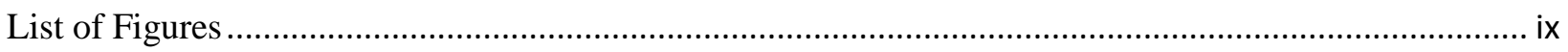

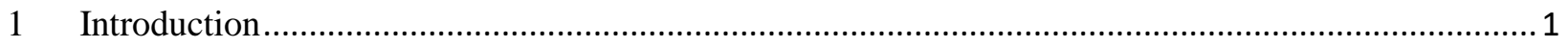

$1.1 \quad$ Research Motivation .........................................................................................................

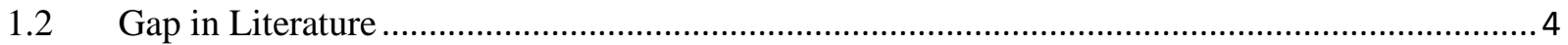

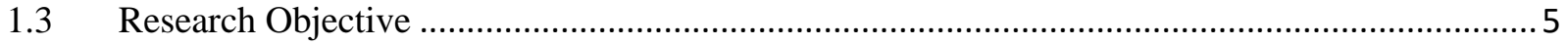

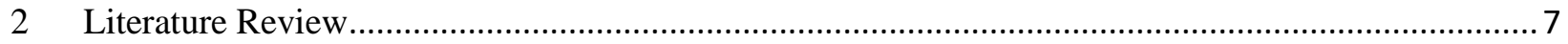

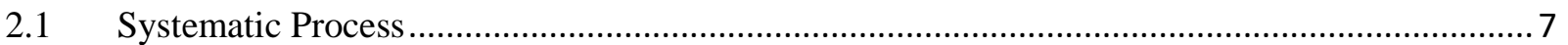

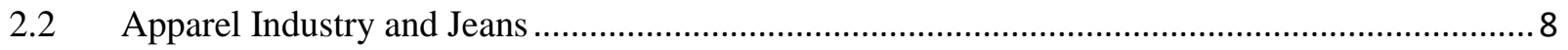

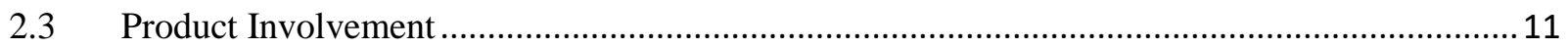

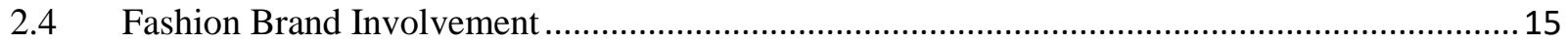

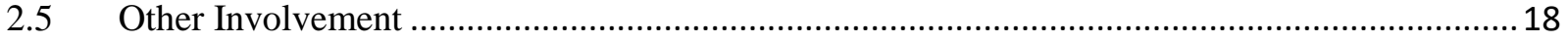

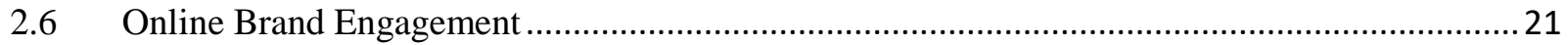

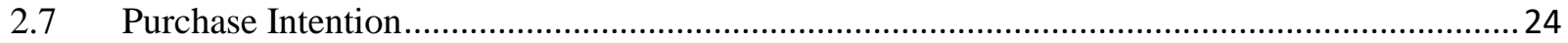

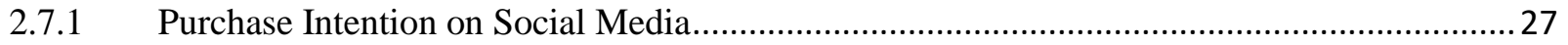

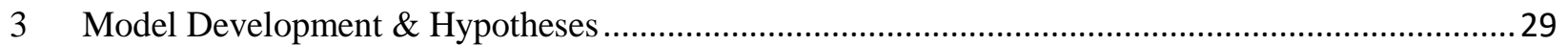

3.1 Theoretical Orientation of Proposed Structural Model ................................................................30

3.2 Product Involvement and Fashion Brand Involvement...........................................................33

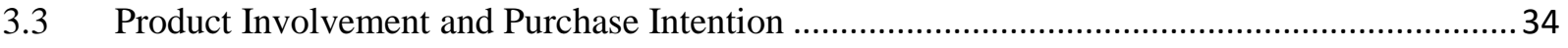

3.4 Fashion Brand Involvement and Online Brand Engagement ................................................35

3.5 Fashion Brand Involvement and Purchase Intention …....................................................... 36

3.6 Online Brand Engagement and Purchase Intention ............................................................. 37

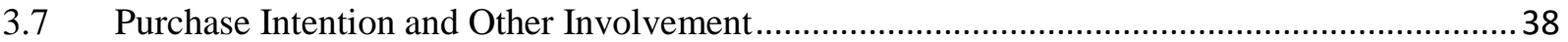

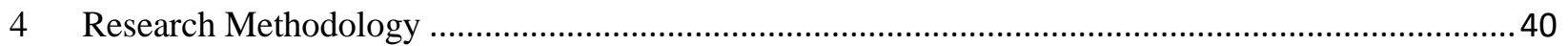

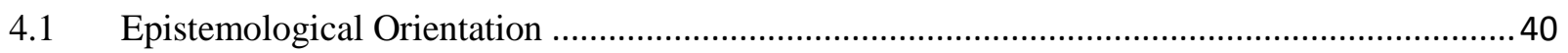

4.2 Partial Least Squares Structural Equation Modeling - PLS-SEM...........................................43

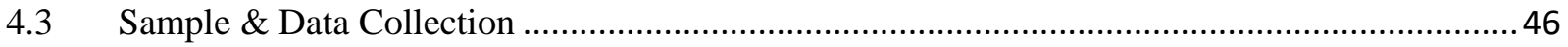

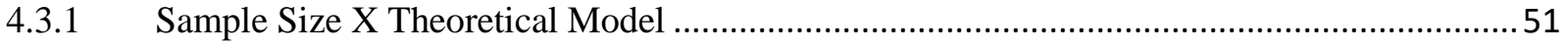

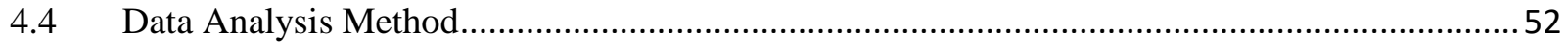




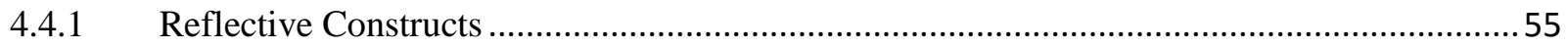

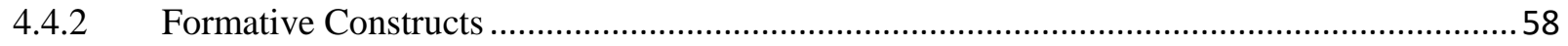

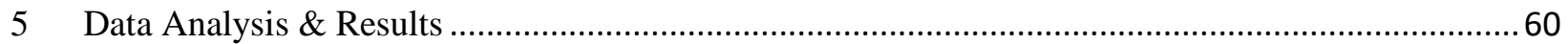

5.1 Assessment of Reflective Measurement Models .......................................................................60

5.2 Assessment of Formative Measurement Models .....................................................................62

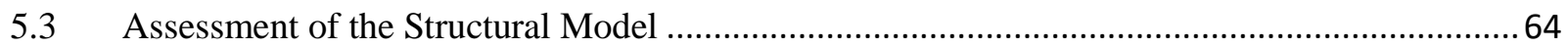

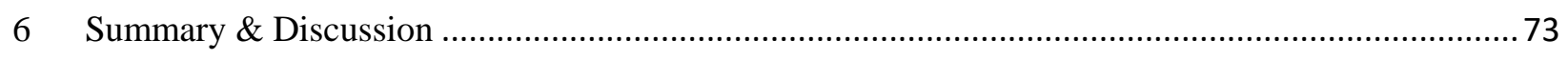

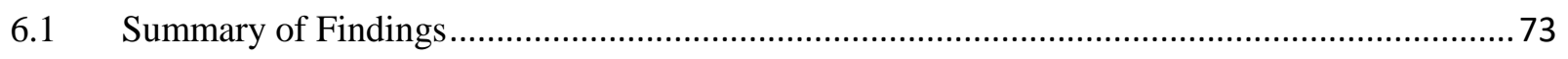

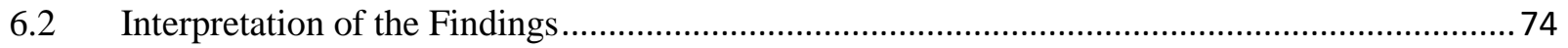

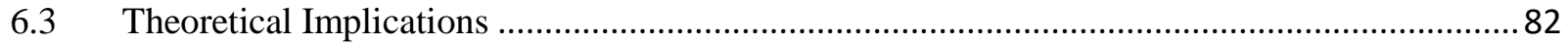

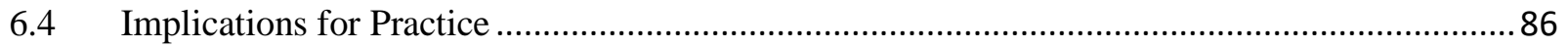

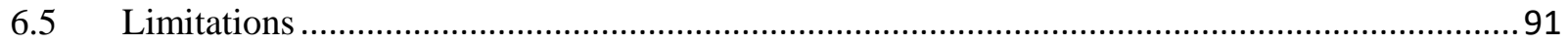

6.6 Recommendations for Future Research ............................................................................ 92

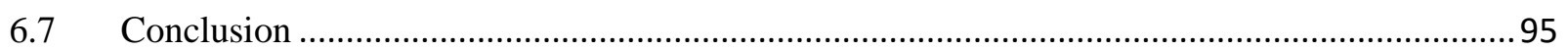

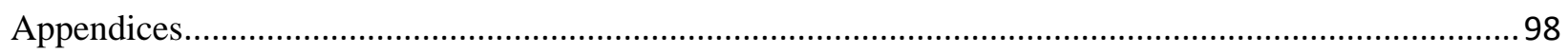

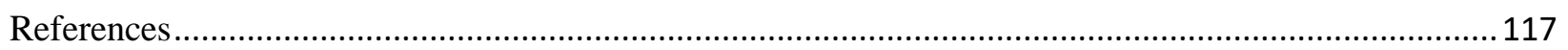




\section{List of Appendices}

A1: $\quad$ Key Findings from Seminal Articles on The Inception of Involvement.................................. 98

A2: $\quad$ Data Construct Descriptions in Alphabetical Order............................................................. 102

A3: Construct Reliability \& Validity Tests: Cronbach's Alpha, Composite Reliability, and Average Variance Extracted..... 105

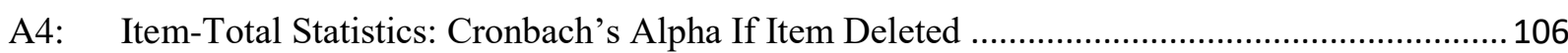

A5: Reliability Statistics: Average Cronbach's Alpha............................................................... 107

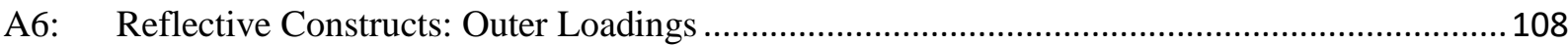

A7: Reflective Constructs: Cross Loadings …............................................................................ 109

A8: $\quad$ Reflective Constructs: Fornell-Larcker Criterion ................................................................110

A9: Reflective Constructs: HTMT Ratio Confidence Intervals Bias Corrected ..............................111

A10: $\quad$ Reflective Measurement Model: Summary of Results ..................................................... 112

A11: Formative Constructs: Redundancy Analysis .................................................................113

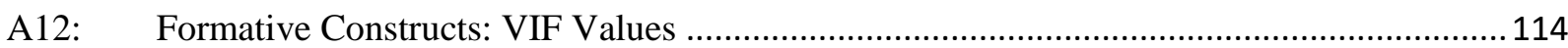

A13: $\quad$ Formative Measurement Model: Summary of Results .................................................... 115

A14: $\quad$ Construct Cross-Validated Redundancy Scores..................................................................116 


\section{List of Tables}

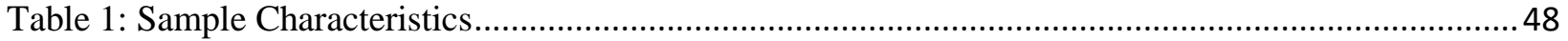

Table 2: Normality Tests: Kolmogorov-Smirnov and Shapiro-Wilks ..................................................54

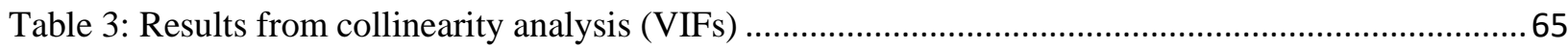

Table 4: Summary of significance testing results for the proposed structural model ..............................66 


\section{List of Figures}

Figure 1: Theoretical Model Illustrating A Consumer's Path to Purchase Jeans in a Social Media Context

Figure 2: Consumer Value Framework adopted from Babin et al. (2017) .............................................32

Figure 3: Model illustrating the results from the R2 and significance tests of the hypothesized paths to the

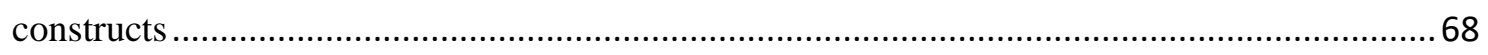

Figure 4: Model illustrating the results from the effect size (f2) ....................................................... 70

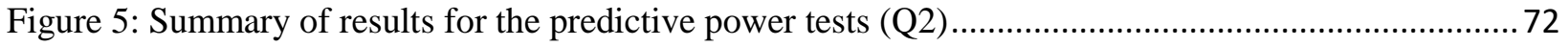




\section{Introduction}

The growth of social media marketing has profoundly transformed consumer experiences, becoming a priority for many business executives today. As $90 \%$ of young adults have integrated social media into their daily lives (Perrin, 2015), stakeholders and decision makers have been trying to recognize profitable methods for firms to employ the use of web applications such as Facebook, Twitter, and Instagram. Historically, people turned to online spaces desiring the privacy it provided to communicate with family and friends (McKenna \& Bargh, 2000); yet now more than ever, people are socializing over the Internet with their peers to expand their networks (Correa, Hinsley, \& De Zuniga, 2010). Two key factors that enable these relationships are social networking sites (SNSs) and instant messages (Ellison, Steinfield, \& Lampe, 2007; Raacke \& Bonds-Raacke, 2008; Valenzuela, Park, \& Kee, 2009). It is reported nearly $65 \%$ of adults are active on social networking sites, indicating a tenfold increase in the previous decade from 2005-2015 (Perrin, 2015). Therefore, it is reasonable to say that social media represents a valuable tool that should be of interest to companies operating in any sector to connect to its consumers.

The rising adoption of Social Networking Sites (SNS) worldwide has rapidly transformed the fashion industry in today's economy (Morris, 2017). As the activity on social networking sites such as Facebook, Instagram, Twitter, and Pinterest continue to rise, the ability to openly communicate one's persona through apparel has solidified the concept of fashion individualism. "In fact, much of the influence of fashion powerhouses on apparel trends have been replaced by 
images, blogs, tweets, videos, etc., created and exchanged by individual consumers and consumer communities on SNSs" (Morris, 2017, p. 2). This was found to be evident particularly on Instagram, a popular photo and video sharing SNS platform which recently garnered attention for being labelled as the heart of the fashion industry (Cartner-Morley, 2015). This is because during the most prominent fashion weeks worldwide, it has been noted attendees customarily turn to their Instagram app, producing a substantial amount of photo and video content and sharing of information during these fashion events. As a result, this impacts the way fashion designers plan, execute, and showcase their runways (Schneier, 2014). For instance, fashion designers such as Tommy Hilfiger and Kenneth Cole have been reported to utilize Instagram for increasing their customer engagement (Park, Ciampaglia, \& Ferrara, 2016).

According to research that analyzed the power of social media, " $70 \%$ of consumers have visited social media sites to get information; $49 \%$ of these consumers have made a purchase decision based on the information they found through the social media sites; $60 \%$ said they were likely to use social media sites to pass along information to others online; and $45 \%$ of those who searched for information via social media sites engaged in word-of-mouth," (Kim \& Ko, 2012, p. 1481). With these large percentages of consumers sharing information amongst each other through social media channels, companies that do not incorporate social media in their advertising approach are losing an important advantage to attain consumers. Kim and Ko (2012) also claim the worth of one customer is significantly far more valuable than what they originally invest. Thus, in order to remain competitive in the market "brands now need to factor in the value of customers and also the influence of social media on them" (Kim \& Ko, 2012, p. 1481). 


\subsection{Research Motivation}

The motivation behind this paper stems from my background as a retail observer and student of retailing for over four years. During my studies, I had a keen interest in marketing and social media. As a millennial observing today's society, the arrival of social media and mobile technologies have brought forth digital disruptions in every industry. Online apps such as Facebook, Instagram, and Snapchat have provided intuitive platforms and connectivity which have transformed the lives of our generation. Through the ease of use brought forth by these platforms, how we spend, purchase, and consume are expected to be as seamless as sending a tweet. However, oftentimes with the integration of new technologies and services, as a consumer our expectations are not always met. Enjoyment has been tested as an influential antecedent of purchase intention (Wen, Prybutok, \& Xu, 2011), however studies have indicated consumers who browse online to seek more information tend to abandon their purchase intentions because they find it tough to enjoy shopping online (Al-Maghrabi, Dennis, Halliday, \& BinAli, 2011). This presents a challenge that must be addressed by retailers to retain customers and acquire new ones. Many retailers have utilized their digital presence in online brand communities and social media channels to cultivate promotional marketing messages that engage consumers and build trust. Yet in today's digital age, retailers will need to rethink their engagement strategies to utilize emerging social media platforms and leverage influence to overcome the noise in the competitive e-commerce market. Through this research, I am motivated to find recommendations for corporations to further connect with consumers and encourage purchase intention, equipping practitioners with a better understanding to develop successful and more efficient marketing strategies that reflect the needs of today's consumers. 


\subsection{Gap in Literature}

Over a decade ago, Hennig-Thurau et al. (2004) brought forth scholarly attention to how the Internet, particularly social media, has revolutionized the ways consumers and marketers communicate. The emergence of social media has not only impacted marketing communications, but consumer decision making processes as well (Hennig-Thurau et al., 2010). While social media has acted as a public sphere for consumers to voice their own opinions for many years, it has also established itself as a source of influence especially over product information and purchase decisions (Kozinets, De Valck, Wojnicki, \& Wilner, 2010). User-generated content and online product reviews have multiplied since the introduction of social media, impacting the use of traditional marketing strategies (Hennig-Thurau, Gwinner, Walsh, \& Gremler, 2004; Trusov, Bodapati, \& Bucklin, 2010). Hence, many researchers have acknowledged the use of social media for communicating marketing messages as well as for transforming how consumers' process information and make decisions (Casteleyn, Mottart, \& Rutten, 2009; Kozinets et al., 2010).

While involvement and engagement have been noted to impact purchase intention and consumption prior to the introduction of social commerce (Bowden, 2009; O'Cass, 2000), there has been limited research to assess their current influence in an online social media setting. Based on the review of significant articles (e.g., Warrington \& Shim (2000), O'Cass (2000), Quester \& Lin Lim (2003)), there is a lack of empirical evidence to understand the role of involvement in purchase implications in a social media context. However, as more and more marketers utilize social media to promote their goods and services, consumers are heavily relying 
on social media to guide their purchases. Therefore, additional research is needed to analyze this phenomenon empirically to advance our understanding of the antecedents of purchase intention when a consumer is shopping in a social network context. Hence, it can be concluded that understanding a new application of involvement can have a significant impact on consumer decision making and thus purchase intention.

\subsection{Research Objective}

This research aims to understand how the intention to purchase jeans can be heightened through product involvement, fashion brand involvement, altruistic involvement, and online brand engagement on social media platforms. Based on the literature and methodology, the research objective is to explore, describe, predict, and evaluate how specific forms of involvement and engagement can lead to purchase intent in the context of advertising on social media platforms by analyzing data extracted from 799 survey responses from North American consumers. From a theoretical perspective, the objective is to investigate how fashion-oriented consumers rely on social media and become influenced by product involvement, fashion brand involvement, altruistic involvement, and online brand engagement activities that can trigger purchase intention. Throughout this research, an extension to the theoretical model on the impact of social network marketing on purchase intention developed by Smith et al. (2016) to include product involvement, fashion brand involvement, and altruistic involvement were proposed and empirically tested. The literature review shows limited studies have assessed its current influence in a social media context today, specifically with a gap in the literature identified on altruistic involvement in social commerce. Hence, this study will build upon their model and specifically 
examine the relationship between product involvement, fashion brand involvement, altruistic involvement, online brand engagement, and purchase intention, to discover new insight into social media and fashion consumption. 


\section{Literature Review}

A comprehensive review of previous literature was conducted around the concepts of product involvement, fashion brand involvement, online brand engagement, purchase intention, and other involvement. The purpose of this literature review is to provide a foundation for the research objective of this study by providing an in-depth synthesis of the knowledge base.

\subsection{Systematic Process}

This literature review examines the development of involvement from 1979 to 2013. To identify relevant literature, credible databases cited in seminal marketing literature were searched. These included Google Scholar, Ryerson University Library and Archives, Association for Consumer Research (ACR), ProQuest, Scholars Portal, Emerald Insight, Research Gate, SAGE, Wiley Online Library, and JSTOR. I then conducted a word search using the search terms involvement, product involvement, brand involvement, and fashion involvement. For inclusion in the literature review, the articles had to be written in English and appear in a peerreviewed journal. The articles had to discuss the evolution and influence of product, brand, and fashion in involvement. Drawing upon the database searches, 40 peer reviewed articles were retrieved. As seen in Appendix A1, an Excel spreadsheet was created to note the research objective, method, and key findings from each article in chronological order, from which the top most cited articles were analyzed. The PDF files of the articles that were recognized as seminal for inclusion were downloaded for further review. Predominantly many U.S. based scholars have contributed to expanding knowledge in these areas (e.g., Ahuvia, 2005; Josiam, Kinley and Kim, 
2005; Park, Kim, and Forney, 2006). Quantitative and mixed methods have also dominated the study of involvement (e.g., Chae, Black and Heitmeyer, 2006; Dellarocas \& Narayan, 2006; Kinley, Josiam and Lockett, 2010). As seen in Appendix A1, the overview of key findings from seminal articles on the inception of involvement show substantial research has focused on product, brand, and fashion involvement, while none of the articles focused on the application of product, fashion brand, and altruistic involvement in a social media context; indicating limited attention has been given towards this area of research. The evolution of these studies indicates the significance of involvement in a social media context has not yet been captured and requires greater research attention, as evident by the lack of articles published in recent years.

\subsection{Apparel Industry and Jeans}

The intersection of fashion in social media has created an unlimited online space of selfexpression (Mohr, 2013) from which unique consumer patterns can be discovered and observed. Data shows revenue from the global fashion and apparel industry is expected to rise from $\$ 481.2$ Billion USD in 2018 to $\$ 712.9$ Billion USD by 2022 (Shopify, 2018). According to Shopify (2018), two notable trends driving this growth are the increasing online access and smartphone penetration, as well as the increasing innovative technologies that provide experiential ecommerce. Social media platforms play a big role not only in engaging and building brand relationships with consumers, but is well on its way to becoming an established channel for ecommerce, particularly in fashion and apparel. For instance, Snapchat recently launched shoppable augmented reality lenses, the Facebook Store app provides convenience as consumers can buy directly through the site, and Pinterest is rapidly expanding beyond a place of discovery 
into an important e-commerce site with its Buyable Pins and Shop the Look features (SmartBrief, 2018). Social media is a driving force in the fashion industry primarily due the integration of direct buying paths it has introduced into the platforms where consumers spend most their time. The incorporation of social media and tech-driven innovation in fashion has developed a more omni-channel marketplace for fashion consumers today. According to the PEW Research Center, the total share of U.S. adults using social media was reported at $69 \%$ in 2018, demonstrating 7 in 10 consumers are social media saavy (PEW Research Center, 2018). Additionally, the fashion consumer's buying power is expected to increase, as the rise of social commerce is projected to grow to more than 1.2 Billion USD by 2020 (Shopify, 2018). This demonstrates the intersection of social media and fashion makes the apparel industry an attractive market to investigate further.

Under the apparel category, jeans were chosen as the most appropriate product for this study. "Initially, denim jeans were adopted for utilitarian purposes associated with physical labour and worn predominantly by ranch hands and farmers," (Rahman, 2011, p. 1). According to Gordon (1991) it was not until the Second World War when jeans were considered as a fundamental commodity required for the national war effort. Rahman (2011) states around the 1950s was the period jeans became associated with fashion as the product made popular appearances on television and movies, becoming heavily adopted by youth. Soon after, a turning point occurred in the 1970s where jeans evolved into a symbol of status through the emergence of popular designer brands such as the establishment of Calvin Klein Jeans in 1978 (Rahman, 2011). Both the classical and contemporary aspects of jeans confirm over the years fashion consumption has transcended beyond physiological needs into love, belonging, and self-esteem. 
This makes jeans an ideal and interesting product to further explore, as the selection and consumption of jeans may continue to evolve in newer contexts such as social media. Furthermore, investigating consumers that purchase fashion and apparel in online brand communities reveals promising data. Recent studies show that the most popular searched products online were apparel and footwear (Agudo-Peregrina, Chaparro-Peláez, \& PascualMiguel, 2014). Furthermore, the number one sector rising in e-commerce sales in both the United States and Canada is the apparel and footwear industry, reporting "US\$37.8 billion and CAD $\$ 1,042.5$ million in sales in 2014 with five-year growth rates of $93.1 \%$ and $66.3 \%$ from 2009-2014,” (Euromonitor International, 2015). As jeans are considered a staple fashion item and universal product consumers will purchase regardless of their age and gender, it is an ideal product to study as it captures the general population.

It is also important to note that clothing has been historically considered as a product category with high enduring involvement (Bloch, 1986; Clarke \& Belk, 1979; Zaichkowsky, 1985). Outcomes that occur as a result of high involvement include extensive decision making, greater product attributes, spending more time and effort during search-related activities (Bloch, 1986), and the formation of brand preferences (Zaichkowsky, 1985). "Since jeans comprise of many attributes (i.e., size, style, and price) it is recognized as a high involvement product category in many historical studies," (Warrington \& Shim, 2000, p. 768). In contrast, the rising trend of athleisure apparel has brought forth a visible threat against denim sales in North America. "A social acceptance of wearing activewear, such as yoga pants and leggings on a daily basis as a substitute [for jeans] has been damaging denim sales," (Euromonitor, 2014, p. 3). As a result of this "soft-dressing" trend, consumers are increasingly wearing fitness apparel while 
running errands or going about other non-related exercise activities in their day. Premium activewear brands such as Lululemon have successfully merged fashion with function to gain social acceptability on par with premium denim through the comfort and style of their yoga pants (Euromonitor, 2014). Consequently, denim brands are taking cues from activewear for fabric innovation. "As consumers continue to integrate sportswear into their daily wear, denim manufacturers have been [researching and developing] fabric innovation, shifting focus towards lightweight knit denim," (Euromonitor, 2014, p. 19). While the evolution of denim continues to shape the position of jeans, it is safe to say it will continue to remain as a wardrobe staple. Its high frequency of wear, fabric innovations, and new developments brought forth to denim will continue to encourage consumers to emit high involvement towards the product.

\subsection{Product Involvement}

Product involvement is described as "the level of personal relevance that a consumer sees in a product" (Wolny \& Mueller, 2013, p. 567), and its intensity is based on the strength of the relationship between the product and the consumer. Understanding consumers' attachments to products can better explain how and why consumers form particular attachments with certain product categories (Laurent \& Kapferer, 1985; Richins \& Bloch, 1986; Zaichkowsky, 1985). Product involvement can also be described as a product-specific phenomenon, with different product categories stimulating different levels of involvement (Bloch, 1981). And depending on the product category, the antecedents of product involvement can also vary too. For instance, consumers that express product involvement towards fashion means they are interested in fashion and involved with clothing, and might also be involved with music because it provides 
an outlet for self-expression (Michaelidou \& Dibb, 2006, p. 442); supporting factors that influence product involvement can vary based on the product. However, regardless of these differences, scholars have continued to research and develop generalised measures to capture product involvement across multiple product categories (Warrington \& Shim, 2000). Historically, product involvement has been similar to the notion of ego involvement (Warrington \& Shim, 2000). Its core stems from psychology and the phenomenon of 'ego involvement', described as the relationship between an individual, an issue or object (Sherif \& Sherif, 1967) and became the basis for the application of involvement in consumer behaviour. Through Krugman (1967)'s study of involvement in advertising, the concept of involvement was gradually applied to marketing and consumer behaviour studies. Throughout the rise of consumer behaviour studies in the 1980s, research began to emphasize the theoretical conceptualization and measurement of involvement in relation to 'objects', commencing the introduction of product involvement to research (Michaelidou \& Dibb, 2006). What remains consistent throughout the conceptualization of product involvement is the notion of "personal relevance', meaning that the degree of product involvement a consumer feels towards an product is established by the extent to which the product viewed as personally relevant (Celsi \& Olson, 1988; Zaichkowsky, 1985). As ego involvement arises when an object matches the characteristics that encompass an individual's self-concept (Sherif \& Sherif, 1967), likewise product involvement also arises once a product matches a person's unique set of values and selfconcept (Houston \& Walker, 1996). Studies have also shown when a certain product relates to a consumer's self-concept, it "produces a tension which is not eased by the use of the product alone, but must be channeled by way of talk, recommendation, and enthusiasm to restore the balance (provide relief)" (Dichter, 1966, p. 148). Product involvement has also been examined in 
relation to other concepts such as information search, brand loyalty, and opinion leadership to name a few (Michaelidou \& Dibb, 2006). However, scholars have yet to understand its impact in a social media context confirming product involvement is an appropriate construct for this study.

When examinng fashion in product involvement, fashion products have been noted for their ability to reinforce a consumers' self-concept (Goldsmith \& Clark, 2008; O'Cass, 2004; Phau \& Lo, 2004). In Michaelidou and Dibb's (2006) study, it was found that consumer interest in fashion is due to the ability of clothing to provide pleasure and enjoyment, as well as its ability to positively shape consumers' self-image. This demonstrates that consumers express interest in clothing not only because of the pleasure it arouses, but also because of its symbolic traits. Studies also show consumers are inclined to consume products that enhance their self-image and personal identity (Elliott \& Wattanasuwan, 1998). And fashion is a product category that represents symbolic consumption, enabling consumers to express themselves (Piacentini \& Mailer, 2004). Consumers who indicate high levels of fashion involvement tend to reflect heavy clothing buyers and possess a passion for fashion (Fairhurst, Good, \& Gentry, 1989). Since clothing acts as a product through which a consumer identifies their self-image to others (Schenk \& Holman, 1980), fashion can be viewed as a communication tool that supports the consumer form a connection to society and gain membership or affiliation within a social group (Gronow, 1993; Holman, 1980). This means consumers show interest in clothing because of its expressive properties that help build their self-image and identity and overall fashion serves as a vehicle to communicate their self-image and identity in a societal context (Holman, 1980). Therefore fashion can be personally relevant, resulting in the consumer to express product involvement in fashion. 
Product involvement has also been historically recognized as an indicator predictive of purchase intention (Evrard \& Aurier, 1996; J.-N. Kapferer \& Laurent, 1985; Laurent \& Kapferer, 1985; Martin, 1998). When examining product involvement and purchase intention, studies have shown product involvement to be influential over a consumer's purchase decision processes (Hollebeek, Jaeger, Brodie, \& Balemi, 2007), especially when browsing or purchasing items. Products are purchased based on its perceived value and benefits portrayed to the consumers and purchasing the right product would lead to greater acceptance from peers and decrease the risk of facing rejection from societal groups (Khare \& Rakesh, 2010). This demonstrates fashion purchases can be governed by social approval. The degree of product involvement expressed by the consumer can also be used to determine consumers' purchase behaviour (Auty \& Elliott, 1998; O'Cass \& Choy, 2008; O'Cass, 2000). In Mittal and Lee's (1989) study it was proposed that purchase may occur without high product involvement, this is because generally consumers don't spend too much time dwelling about their soap, toothpaste, or light bulb purchases despite its daily use. However, if it is a high involvement product category, such as fashion which generally exhibits high levels of involvement (Wolny \& Mueller, 2013), then the decision to purchase would not be made causally. This is because when a consumers expresses greater interest in a product it has high significance with their self-image; hence as a result, consumers would spend more time evaluating the different alternatives in the product category before making a purchase (Khare \& Rakesh, 2010). This is in line with Mittal and Lee's (1989) study that stated product involvement was an antecedent of the purchase decision. Therefore, the greater the degree of product involvement consumers' express towards a product, the more 
involved consumers will be in its purchase decision, making it an appropriate construct to add to this study as it can be viewed as an influence leading to purchase intention.

\subsection{Fashion Brand Involvement}

Apart from product involvement, it is also appropriate and pertinent to examine brand involvement in the fashion industry. Brand involvement, is described as "positive feelings of attachment to a brand and is characterised by a tendency to withstand changes," (Wolny \& Mueller, 2013, p. 566). Fashion brands specifically are widely popular for its symbolic nature and can evoke passion and attachment from consumers (Das, Agarwal, Malhotra, \& Varshneya, 2019). The power behind fashion brands come from its ability to communicate a persona, either directly through its apparel or indirectly through marketing, retail experience, etc. "For instance, Levi Jeans elicit a feeling of excitement, fashionable, youthful and outgoing," (Rageh Ismail \& Spinelli, 2012, p. 389). Consumers express passion towards fashion brands that satisfy them and can internally arouse looking and feeling good. Hence, consumers who form a connection with a fashion brand often feel emotionally attached to these brands (Rageh Ismail \& Spinelli, 2012). Many corporations harness the power of these brands to build a relatable image that produces loyalty and establishes deep relationships with customers (Keller, 1993; Shocker, Srivastava, \& Ruekert, 1994). The rise of social media has also further benefited fashion brands by attracting customers to interact and build relationships with fashion brands (Kim \& Ko, 2012). As a result, the communication and interaction that occurs with consumers on social media platforms can create interest and affection towards the brand and influence a consumer's purchase intention. 
Hence, understanding fashion brand involvement has practical relevance to marketers due to its influence on a company's profitability.

It is also imperative to recognize consumers are sensitive to the type of brands they consume (Eisingerich \& Rubera, 2010), especially in a fashion brand context and will not use brands that do not align with their own self-image. As clothing plays a role in communicating not just personal identities, but social identities (Noesjirwan \& Crawford, 1982), brands play a significant role in conveying these social cues. Research also highlights that a brand must seem to be a part of the consumers' identity to induce affection and brand involvement (Ahuvia, 2005). Therefore, the deeper the brand connection to a consumer's self-image, the stronger the brand involvement will be. The recurring nature of clothing shows people are continually attracted to the latest fashion of the season, implying the pivotal role of fashion in society and the significance of brand involvement in fashion (O’Cass, 2000). Nevertheless, since fashion possesses diverse meanings to various consumers, attraction can vary from family to friends in terms of strength and level of attachment. These emotional brand connections are highly evident amongst fashion brands, as they depend heavily on emotional differentiation, rather than utilitarian product differentiation (Wolny \& Mueller, 2013). Hence for high brand involvement to take place, a consumer's self-concept and beliefs should mirror the values and beliefs fashion brands portray.

When further examining purchase intention in fashion brand involvement, consumer attitude towards a brand is very influential in the decision-making process. In Auty and Elliot's 
(1998) study of meanings associated with branded and unbranded jeans, Levi jeans were perceived to be much more well known than were the unbranded pair, testifying the strength of fashion brands in producing favourable consumer attitudes and purchase intention compared to unbranded products. Grant and Stephen's (2005) study also showed fashion brands had a strong influence on the purchase intention of fashion. Since the attachment of fashion brands can occur on an emotional level (Kotler \& Bliemel, 2001), consumers purchasing fashion brands can be attributed to satisfying their needs, to communicating their identity, and to forming self-brand connections that enable the expression of their actual or ideal dimensions of the self," (Tong, Su, $\& \mathrm{Xu}, 2018$ ). Additionally, fashion brand involvement also determines the price consumers are willing to pay for fashion brands. Studies show consumers are willing to pay a premium for a more popular branded product (Grant \& Stephen, 2005), and that brand-conscious consumers spend more on fashion products than those who are brand-unconscious (Giovannini, Xu, \& Thomas, 2015). Research also shows fashion consumers that express attachment to certain fashion brands are more inclined to purchase from those specific brands compared to less known brands as they spend less time shopping for a familiar brand versus an unfamiliar brand (Rahman \& Mannan, 2018). Overall, the literature highlights the importance of fashion brand involvement in influencing consumers' purchases, demonstrating its significance in this research.

When examining fashion brand involvement on social media, many fashion brands use social media platforms to create an online attachment to their brand. Through online reviews from existing customers, social media is not only a platform to provide knowledge in regard to a product or service, but brands are promoted as well gaining trust from new consumers (Lin, Lu, $\& \mathrm{Wu}, 2012)$. Consumers often portray their self-concept through the brands they choose to 
wear, and the expression of self-concept through fashion brands has become increasingly popular especially on social media (Samala \& Singh, 2018). Specifically within a retail context, social media has accelerated the accessibility of fashion brands to consumers (Lipsman, Mudd, Rich, \& Bruich, 2012). In a recent study around fashion brand content on Facebook, it was found social media encourages consumers to share their opinions and apply their influence on surrounding peers as well as on brands (Kim \& Johnson, 2016). Since social media allows consumers to receive information and share their individual views, consumers are no longer passive recipients of brand information but producers and distributors of information as well (Stewart \& Pavlou, 2002). Thus, social media has provided a platform for consumers to become more involved and interested in new fashion brands as well. Overall, the literature highlights the importance of social media in generating fashion brand involvement, also demonstrating its significance in this research.

\subsection{Other Involvement}

Another pivotal construct used in this study is "Other Involvement" in which Wolny and Mueller (2013) define as concern for others. This construct can be traced back to the 1990's where it has been identified as the need to help others (Price, Feick, \& Guskey, 1995) and is recognized in literature as synonymous to altruistic behaviour; doing something for others without the expectation of gaining something in return (Sundaram, Mitra, \& Webster, 1998). In a commercial context, altruistic involvement is defined as "a genuine desire to help a friend or relative make a better purchase decision," (Hennig-Thurau et al., 2004, p. 41). Similarly, other involvement has been identified as a word-of-mouth (WOM) action that represents the need for 
giving to others (Dichter, 1966). Thus, altruistic involvement can be described as other involvement as they both indicate the need to help others (Wolny \& Mueller, 2013). Research has also argued that the concern for other consumers can be an innate capacity found in everyone (Smith, Coyle, Lightfoot, \& Scott, 2007) and that it is an essential human need to offer advice and help others. Therefore, it should be recognized that consumers have a natural concern or altruistic involvement in the welfare of others.

Studies have also revealed that concern for others expressed on social media platforms was a key motivational factor behind attracting visits and producing comments on these pages (Hennig-Thurau et al., 2004). When examining altruistic drives, obligation and the ability to obligate others has been proven to engage social media users in WOM communication; as consumers either feel indebted after receiving information hence participate in WOM or wish to obligate others to reciprocating information through WOM (Gatignon \& Robertson, 1985). While extrinsic motivations (i.e. driven to achieve tangible rewards or goals (Vallerand, 1997)) to spread eWOM have been widely studied, this research will emphasize the impact of altruistic involvement on eWOM during post-purchase settings and how firms can benefit from this intrinsic motivation. Additionally, altruistic behaviour has also been noted as a key driver for sharing e-mail advertisements within SNS settings (Ho \& Dempsey, 2010; Kukla, 2012; Phelps, Lewis, Mobilio, Perry, \& Raman, 2004). In a recent study, Hayes and King (2014) identified three types of key sharing behaviour commonly found in eWOM: opinion seeking, opinion giving, and opinion passing- each triggered by unique motivations. Opinion seekers aim to seek information from others, opinion givers provide information that can influence others' opinions, and opinion passing commonly takes place in an online setting such as social media where 
multidirectional communication can occur and opinions can be forwarded to one another (Hayes \& King, 2014). Opinion giving and opinion passing are both forms of eWOM that have been noted in previous studies to be fueled by altruistic involvement (Hennig-Thurau et al., 2004; Smith et al., 2007). This is not a surprise as "altruism has been found to be an antecedent to marketing helping behavior," in the late 2000s (Smith et al., 2007, p. 388). Fashion and apparel also appear to be one of the largest sectors where altruistic drives motivate users, as "fashionstyling advice and apparel-purchase advice are just some of the ways users may be helping others in social media contexts," (Wolny \& Mueller, 2013, p. 568). Since the purchase decision depends heavily on style and sizing advice shared through WOM, altruistic involvement is an appropriate construct to research in this study.

Social media and the internet function as communication channels that allow individuals to share information, knowledge, and experiences. In fact, "brand advertisers rank 'sharing via social networks' as a top metric for evaluating online success," (Hayes \& King, 2014, p. 1). Studies show individuals only contribute knowledge if they can expect to receive benefits that outweigh the costs of contributing (Bock, Zmud, Kim, \& Lee, 2005). This can explain why mainly inactive users show sudden activity during social media contests and prize giveaways that require comments and the contribution of knowledge to be entered. However, more recently scholars have argued on the contrary that "knowledge sharing is more likely to occur when individuals are motivated," (Chang \& Chuang, 2011, p. 11). Historical research in consumer behavior and psychology show that purchase experiences create positive/negative emotions, resulting in a powerful source of motivation (Westbrook, 1987). This motivational outcome then leads to WOM communication, complaints, or repurchase intentions, also known as post- 
consumption behavior (Westbrook, 1987). It is important to recognize the sentiment of consumption experiences determines the sentiment of WOM communication. As other involvement is the need to help others, consumers may write either positive or negative experiences to protect and guide other consumers in making better purchase decisions. Therefore, a relationship lies between consumption experiences and motivations such as altruistic involvement, and post-consumption behaviour such as WOM (Sundaram et al., 1998). It was even discovered that "altruism was more influential than extrinsic rewards in determining online knowledge sharing" (Chang \& Chuang, 2011, p. 16). This may be of importance to corporations interested in developing and sustaining organic referrals in their business, as large investments to implement extrinsic rewards may not be required to produce positive eWOM from their consumers.

\subsection{Online Brand Engagement}

While the concept of engagement has been acknowledged across various academic disciplines including the social sciences and organizational behavior, engagement has only recently emerged in marketing literature (Brodie, L. D. Hollebeek, B. Juric, \& A. Ilic, 2011; Leeflang, 2011). Online brand engagement is essentially brand engagement that occurs in an online setting. It is defined as "the cognitive and affective commitment to an active relationship with the brand as personified by the website or other computer-mediated entities designed to communicate brand value," (Mollen \& Wilson, 2010, p. 5). It encompasses an interactive relationship gained through exchanges with the brand on an online platform (Wirtz et al., 2013). A consumer can establish a deep bond on an emotional, cognitive and behavioural level simply 
by engaging with a brand. Hence, scholars claim that "customer brand engagement [both in an online and offline context] is the only really significant concept when considering engagement from the marketing perspective," (Gambetti \& Graffigna, 2010, p. 819). Engagement encompasses an intrapersonal process in which consumption emerges from a consumer's values for the product (Patterson, Yu, \& De Ruyter, 2006; Sprott, Czellar, \& Spangenberg, 2009), and has also demonstrated to be drivers of brand loyalty, commitment, trust, and consumer satisfaction (Brodie et al., 2013; Hollebeek, 2011). "However, despite the growing scholarly interest regarding the undertaking of marketing research addressing 'engagement,' studies have been predominantly exploratory in nature; thus, generating a lack of empirical research in this area to date," (Hollebeek, Glynn, \& Brodie, 2014, p. 2).

In the last two decades, the notion of brand engagement emerged with the influx of consumer/brand relationship studies emphasized in consumer behaviour research (Aaker, Fournier, \& Brasel, 2004; Abdullah \& Siraj, 2018; Bolton, 2011; Calder, Malthouse, \& Schaedel, 2009; Dessart, Veloutsou, \& Morgan-Thomas, 2015). And now more than ever, social media has also become an important research setting in which brand engagement is increasingly discussed in an online context (Erdoğmuş \& Tatar, 2015; Geissinger \& Laurell, 2016) that can arise as a result of interactive and collaborative customer experiences with a brand. (Brodie et al., 2011; Hollebeek, 2011; Patterson, Yu, \& De Ruyter, 2006). As consumers progressively depend on the Internet for product knowledge and purchases (Kim, Bae, \& Kang, 2008; Shankar, Smith, \& Rangaswamy, 2003), they increasingly communicate their personal interests and needs to others through social media (Hollebeek, 2011). Hence, many brands have opted to online platforms to develop stronger relations with consumers. Through this viewpoint, it can be said that consumers 
interact with products not only due to individual benefits, but primarily as a direct consequence of a consumer's self-concept (van Doorn et al., 2010). Hence, behavioural activities such as posting and blogging should be viewed as expressions of online engagement linked to individual interests (Sprott et al., 2009).

In respect to the dimensionality of online brand engagement, a lack of consensus prevails among scholars. Hollebeek (2011), the most cited brand engagement study proposed it to be compromised of cognitive, emotional and behavioural activities that occur in brand relationships. Cognitive brand engagement represents an individual's attentiveness or obsession in the brand, emotional brand engagement represents an individual's brand-related passion, and behavioural brand engagement represents an individual's energy from interacting with the brand (L. D. Hollebeek, 2011). In contrast, Calder et al. (2009) argued online engagement was comprised of eight dimensions (Stimulation and Inspiration, Social Facilitation, Temporal, Self-Esteem and Civic Mindedness, Intrinsic Enjoyment, Utilitarian, Participation and Socializing, and Community), whereas Mollen and Wilson (2010) claimed online brand engagement was composed of three unique dimensions (cognitive processing, instrumental value, and experiential value). Therefore, it can be said online brand engagement embodies a multi-dimensional concept (L. Hollebeek, 2011), and "the specific expression of engagement dimensions may vary across contexts," (D. Hollebeek \& Chen, 2014, p. 64). In agreement with Hollebeek (2011) and Brodie et al. (2011), consumers are presumed to cognitively absorb and acquire knowledge about products on social media, and then become emotionally attached to the brand, resulting in engagement-based behaviours and interactive activities that express their co-creative and active nature (Abdullah \& Siraj, 2018). Hence, in this paper the dimensions of online brand 
engagement are adopted from Hollebeek (2011) and include cognitive, emotional, and behavioural facets.

\subsection{Purchase Intention}

Purchase intention is defined as a phase in the consumer decision-making process that occurs when the consumer has formed a real willingness and readiness towards a product or brand (Wells, Valacich, \& Hess, 2011). The consumer decision-making process includes various stages an individual undergoes when deciding to acquire a good or service. This process begins with identifying a need, then conducting a pre-purchase search to gather information about methods to meet their need, followed by an assessment of alternatives prior to the physical purchase, concluding with processes that occur post-purchase including the customer satisifaction gained from the experience and an assessment of the purchased item (Hutter, Hautz, Dennhardt, \& Füller, 2013). Hence, purchase intention is described as the perceptual conviction consumers form subsequent to conducting an overall assesment to purchase (Dodds, Monroe, \& Grewal, 1991; Engel, Blackwell, \& Miniard, 2001; Shao, Baker, \& Wagner, 2004). In addition to a consumer's willingness to buy, purchase intention is also comprised of a future intention to purchase, and the inclination to repurchase (Balakrishnan, Dahnil, \& Yi, 2014). Historically, it has been demonstrated that consumers possess an inherent inclination to compare their prepurchase expectations to their actual purchase experience (Oliver, 1980). If the actual purchase experience fails to meet pre-purchase expectations, negative post-purchase customer responses such as disappointment or frustration will arise; on the other hand, if the actual purchase 
experience surpasses pre-purchase expectations, then positive post-purchase customer responses such as pleasure or enjoyment will arise (Berman, 2005).

It is important to note purchase intention can be used to indicate purchase behaviour as consumer behaviour can be forecasted based on intentions (Ajzen \& Fishbein, 1980). This is because “consumers' self-reported intentions represent easy-to-collect proxies of behavior, thus have been used widely in academic and commercial research," (Chandon, Morwitz, \& Reinartz, 2005 , p. 1). Studies show most companies depend on consumers' intentions to purchase in order to predict the adoption rate of new products and repeat purchases of existing ones (Jamieson \& Bass, 1989). Furthermore, studies also show that requesting consumers to forecast their future behavior, increases the probability that they will engage in that behavior (Sherman, 1980; Spangenberg, 1997; Spangenberg \& Greenwald, 1999; Spangenberg, Sprott, Grohmann, \& Smith, 2003). Hence, the intention to purchase can be described as a psychological variable that intervenes between inclination and physical behaviour (Miniard \& Cohen, 1983), and is adopted in this study to predict purchase behaviour.

There are a variety of theories that can be used to understand a consumer's purchase intention. Nonetheless, in this research the theory of reasoned action will be discussed to understand how and what drives a consumer to purchase. Ajzen and Fishbein (1975) describe that theory of reasoned action (TRA) is driven by behavioural intentions that result from individual beliefs and perceived norms associated with a certain behaviour. This behavioural intention is driven by two conceptually distinct beliefs- behavioural and normative (Ajzen \& 
Fishbein, 1980). Behavioural beliefs are the underlying influence of an individual's attitude towards performing the behaviour- including previously formed favourable and unfavourable opinions that develop an attitude towards the behaviour. Normative beliefs are the underlying influence of an individual's subjective norm or perceived social pressure about performing the behaviour. Hence, beliefs can impact behavioural intentions and subsequent consumer behaviour through attitudes or subjective norms (Madden, Ellen, \& Ajzen, 1992). Therefore, it can be concluded that a positive attitude and subjective norms would increase the probability of an individual in performing the intended behaviour (Adenan, Ali, \& Rahman, 2018). In terms of this research, product involvement reflects a cognitive and emotional form of influence that can impact a consumer's attitude towards purchase. It includes expressing joy or disappointment about a product (Hennig-Thurau et al., 2004; O'Cass, 2004). Hence, product involvement can be characterized as a behavioural-based belief that forms an attitude towards the intention to perform a purchase. Fashion brand involvement entails identifying with others who wear similar fashion brands, the importance to purchase the right fashion brand, and the effort in selecting the right fashion brand (Wolny \& Mueller, 2013). The fashion brand represents a favourable image that would improve the consumer's self-image and social status which would lead to improving their subjective norm. Thus, fashion brand involvement reflects a normative belief as an emphasis to conform to social norms exists within this construct. And online brand engagement can be characterized by both normative and behavioural elements. It contains of a sense of pride that stems from showing others one's affiliation with fashion brands, and the need to closely follow fashion brand news (Campbell, Ferraro, \& Sands, 2014), indicating a social pressure to conform to norms. In addition, it contains an inherent interest in learning more about brands that are present online and an interest in receiving communications from them, developing a positive 
attitude towards purchase. Thus, the theory of reasoned action can be applied to this research to better understand how an inherent attachment and engagement to products and fashion brands can exert influence on a consumer's intention to purchase.

\subsubsection{Purchase Intention on Social Media}

Purchase intention is also heavily influenced by social media interactions (Hutter et al., 2013), and in a marketing context purchase intention has been used as an indicator of actual purchasing behaviour (Campbell et al., 2014). As consumers devote more of their time on social media platforms such as Facebook and Instagram, the probabilty of being influenced to purchase

from social media interactions has increased consequently. The key target for all advertisers and marketers is to influence consumers to form a willingness to buy their marketed product or service. Hence, the effectiveness of social media, websites, and other online brand engagement platforms will be measured against purchase intention. The increasing prevalence of online media has also provided new and unique occasions for corporations to connect with consumers during their purchase journey. Recently, it was reported that search engines and social media were the top two forms of online media commonly used (Srinivasan, Rutz, \& Pauwels, 2016). Following the advent of social media as mainstream media, countless users have produced extensive online user-generated content that has received attention from many big corporations as a prominent source of producing purchase intention (Goh, Heng, \& Lin, 2013; Liang \& Turban, 2011; Luo, Zhang, \& Duan, 2013). The wide acceptance and recognition of social media, along with the increasing importance to dominate this social market have caused an awareness amongst businesses to better understand and recognize how social media interactions 
influence purchases. Conveniently, the introduction of e-commerce and online shopping has benefited both marketers and consumers compared to traditional in-store platforms. Particularly, it has removed challengers pertaining time and space and has simplified the information search process; a key stage in the process of all purchase decisions (Hoffman \& Novak, 1996; Peterson, Balasubramanian, \& Bronnenberg, 1997). However, it's downfall is that online consumers cannot physically inspect or experience a product at the time of purchase (Cui, Lui, \& Guo, 2012; Moon, Chadee, \& Tikoo, 2008). On the contrary, social media studies have demonstrated the effectiveness behind consumer-generated content, such as eWOM in triggering purchase intent (Cui et al., 2012; Luo et al., 2013; Stephen \& Galak, 2012; Trusov, Bucklin, \& Pauwels, 2009). "Research shows that $26 \%$ of consumers have increased positive attitudes towards ads posted by friends and another $26 \%$ find ads targeted using their profile information acceptable," (Srinivasan et al., 2016, p. 2). In comparison to marketing messages brought forth by businesses, consumers are more inclined to share WOM communication prior to committing to any purchase because of the credibility and reliability behind user-oriented communication (Bickart \& Schindler, 2001). Consumers become informed about a product when a substantial amount of peer discussion about a brand occurs. Therefore, regardless of the challenges that may come with online shopping, it can be said that consumers who gain knowledge and brand awareness through social media might be more inclined to purchase compared to consumers who gain brand awareness from traditional sources of media (Olbrich \& Holsing, 2011; Trusov et al., 2009). Thus, it is vital that activities conducted on social media contain purchase-related intentions (Liang \& Turban, 2011). 


\section{Model Development \& Hypotheses}

Figure 1 illustrates the theoretical model that will be further investigated in this thesis. This model aims to understand the relationships that exist when a consumer purchases jeans in a social media setting from influences such as product involvement, fashion brand involvement, other (altruistic) involvement, and online brand engagement. In the context of how social media serves as a platform for consumers to connect with fashion brands, three hypotheses represented by the solid paths in Figure 1 were tested by Smith et al. (2016). Additionally, three new hypotheses in the same context, represented by the dotted paths in Figure 1 will be tested to extend the model and further contribute to understanding a new application of product, fashion brand, and altruistic involvement, and its impact on consumer decision making and purchase intention on social media platforms.

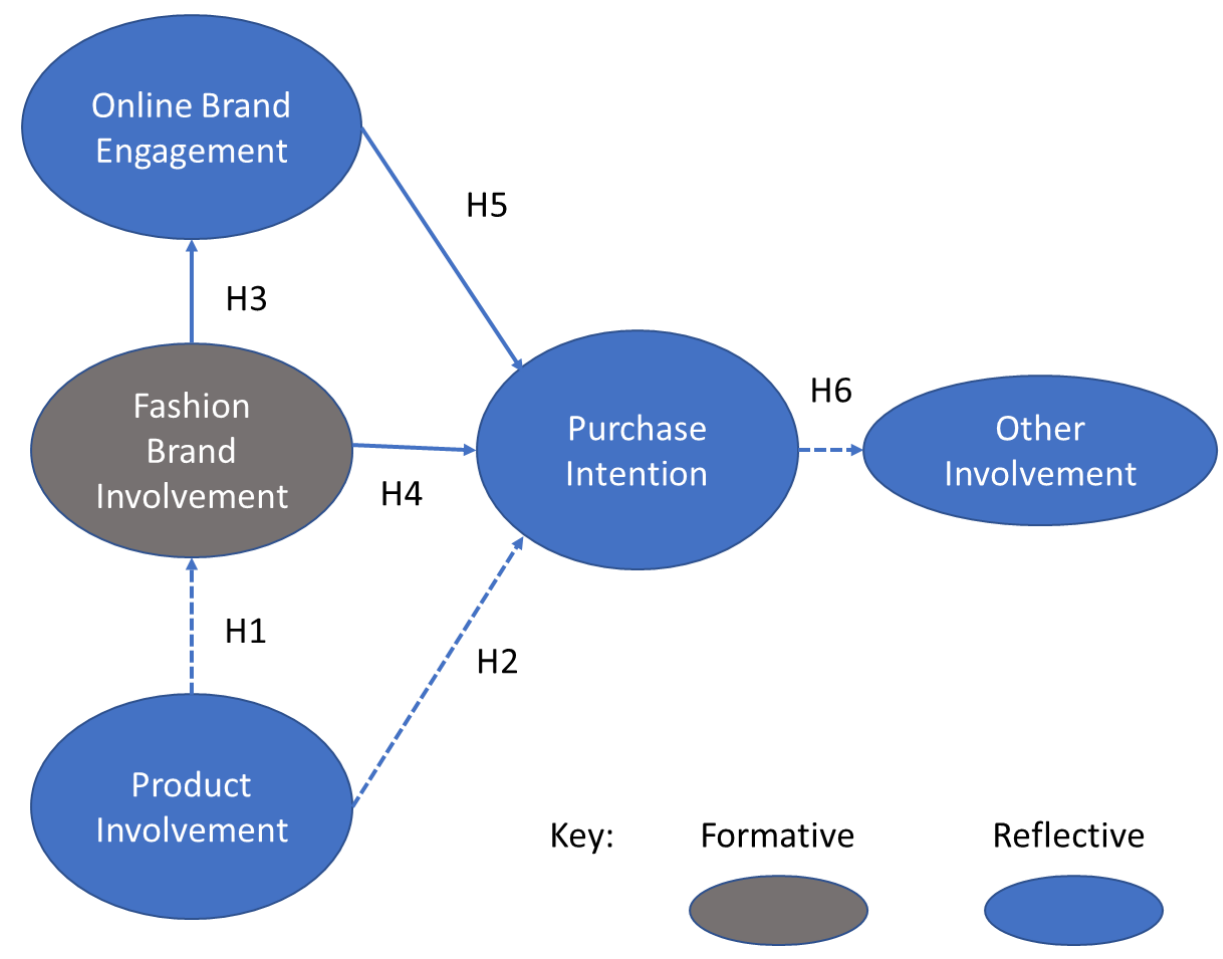

Figure 1: Theoretical Model Illustrating A Consumer's Path to Purchase Jeans in a Social Media Context 


\subsection{Theoretical Orientation of Proposed Structural Model}

Researchers have characterized consumer behaviour as a multidimensional concept (Hess \& Story, 2005; Yoo \& Donthu, 2001). The study of consumer behaviour not only encompasses many disciplines but includes multiple factors that can impact the intention to purchase and the experience post-purchase (Lu \& Yu-Jen Su, 2009; Njite \& Parsa, 2005). The consumer value framework proposed by Babin et al. (2017) was selected to explain the theoretical orientation of the proposed structural model. This framework is illustrated in Figure 2 below and provides insight into consumption-related behaviours and the factors that determine the value associated with consumption to gain a better understanding of the consumer decision-making process. Given the potential complexity involved in explaining factors that affect consumption, Babin et al. (2017) divide these factors into two key categories: internal and external influences. Internal influences involve the internal psychology and personality of the consumer, while external influences involve the social environment and situational sources of influence from outside the consumer.

In the proposed structural model, product involvement and fashion brand involvement embody motivation. Babin et al. (2017) describe a consumer's motivation as the internal drive behind consumer actions. They state "involvement is synonymous with motivation in the sense that a highly involved consumer is strongly motivated to expend effort and resources in consuming a particular thing," (Babin \& Harris, 2012, p. 90). As a consumer needs to express some level of involvement to effectively evaluate multiple products and fashion brands, product involvement and fashion brand involvement exemplify motivation which reflects an internal 
influence. On the other hand, online brand engagement embodies the internal personality of the consumer. Babin et al. (2017) describe consumer personality as the cognitive, affective, motivational, and behavioural aspects a consumer exhibits consistently as they adapt to their environment. Online brand engagement depicts a cognitive and affective form of commitment with a brand (Mollen \& Wilson, 2010), and "personality traits are important in the formation and maintenance of these consumer-brand relationships" (Babin \& Harris, 2012, p. 116). Hence, online brand engagement can be characterized by personality which also reflects an internal influence. These internal influences are processed inside the mind of the consumer and can be thought of as part of the consumer. Internal perceptions influence the appeal of products, which impacts the decision-making processes and perceived value from consumption (B. J. Babin, K. B. Murray, \& E. G. Harris, 2017). Therefore, in the development of the proposed structural model, product involvement, fashion brand involvement, and online brand engagement is demonstrated to impact purchase intention, representing the impact of internal influences on consumption.

Babin et al. (2017) state choice is a consumer's decision to purchase. Consumers may postpone or forgo a purchase altogether, hence choice closely reflects an intention to purchase. In the consumer value framework choice is reflected under the consumption process as an exchange (Babin, Murray, \& Harris, 2017). Once a purchase takes place, cost and benefits, reaction, and value are outcomes that occur post-purchase. Since altruistic involvement reflects the need to help others make a better purchase decision based on a personal purchase experience, altruistic involvement reflects a reaction which occurs post-purchase. Reactions entail more than satisfaction experienced post-purchase, it may include pleasure, disgust, shock, and even 
irritation to name a few. These reactions are important because they are often linked to a behaviour (Babin et al., 2017). When positive disconfirmation occurs, performance perceptions exceed consumers' expectations which can result in positive eWOM. This demonstrates altruistic involvement as consumers desire to help others with their positive purchase experiences (Hennig-Thurau et al., 2004). Likewise, when negative disconfirmation occurs, performance perceptions fail to exceed consumers' expectations which can result in negative eWOM. This also demonstrates altruistic involvement as consumers also desire to warn others with their negative purchase experiences (Hennig-Thurau et al., 2004). Overall, the customer value framework is beneficial for establishing consumer behaviour knowledge and supports the development and theoretical orientation of the proposed structural model.

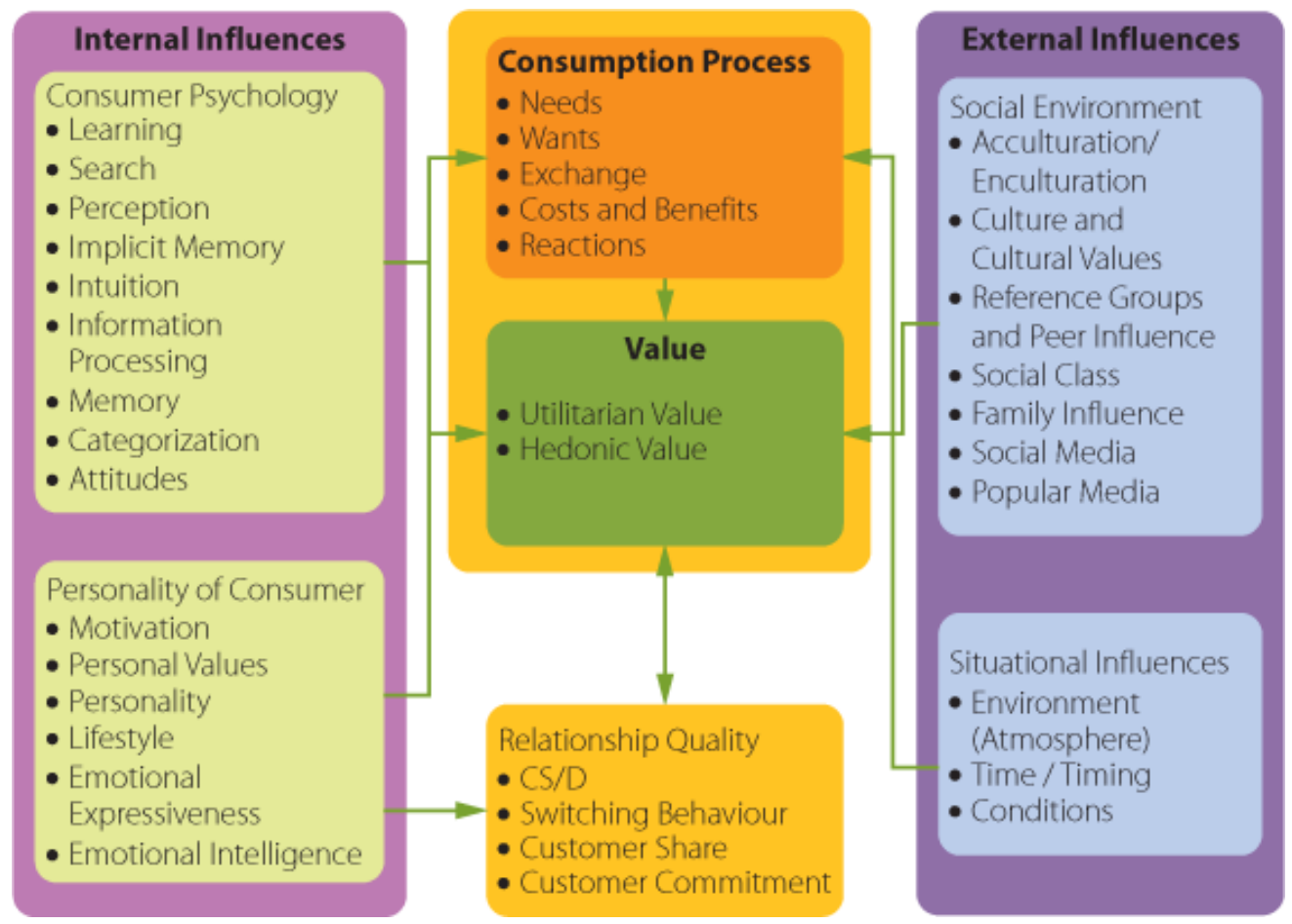

Figure 2: Consumer Value Framework adopted from Babin et al. (2017) 


\subsection{Product Involvement and Fashion Brand Involvement}

Product involvement is described as the personal relevance a consumer sees in a product (Wolny \& Mueller, 2013). In early literature, Mittal and Lee's (1989) research that examined jeans and VCRs, reported that "product involvement proved significant as an antecedent of brand decision involvement" (Mittal \& Lee, 1989, p. 384). This can also be seen in Davis' (2002) study which found that a strong connection with a product can impact consumers' feelings of attachment to the brand. Manning (2010) explains the affective attachment a consumer expresses towards the product, are the very means through which individuals develop an attachment towards a brand, hence product involvement can be viewed as an antecedent to fashion brand involvement. Researchers have also found that positive feelings of attachment towards a product can increase individuals' willingness to make repeated purchases of the same brand (Pedeliento, Andreini, Bergamaschi, \& Salo, 2016, p. 2). This is because the positive feelings that individuals develop toward a product, can also be transferred to the brand (McAlexander, Schouten, \& Koenig, 2002; Mugge, Schifferstein, \& Schoormans, 2010). Thus, firms often extend successful brand names to new product launches, leveraging the existing emotional values and ties to them to carry a consumer beyond product involvement, (Kotler \& Gertner, 2002). In a fashion context, involvement in fashion was demonstrated to have a large influence on the perceived status and attitudes of fashion brands (O'Cass \& Choy, 2008). Since fashion brands have been noted to possess a symbolic nature (Das et al., 2019), fashion brands plays an important role in emotionally connecting and carrying a consumer beyond their involvement with clothing (Kim \& Sullivan, 2019). Therefore, the following hypothesis is proposed:

H1: There is a positive relationship between product involvement and fashion brand involvement 


\subsection{Product Involvement and Purchase Intention}

Firms are increasingly using social media to advertise their products as consumers are increasingly spending more time on social media. Historically, studies have found product categories such as jeans to demonstrate high product involvement (Clarke \& Belk, 1979). In former studies, product involvement has also been shown to be highly predictive of purchase intention (Martin, 1998). Scholars have found when the degree of product involvement is high, the degree of purchase intention is also high (Hollebeek et al., 2007; Prendergast, Tsang, \& Chan, 2010). Babin et al. (2012) proposed that consumers who express high product involvement can be found in fashion, and that these consumers find great satisfaction in learning, wearing, and shopping for fashion. Thus, the degree of product involvement can influence and lead a consumer to forming purchase intention (Huang, Chou, \& Lin, 2010). Moreover, in an online study it was found that social media websites serve as an open platform that enables consumers to express individual opinions, as well as acquire product information that facilitates their purchase decisions (Kozinets et al., 2010). This finding can be supported by a more recent study that found consumers who use social media such as Snapchat geofilter ads had a greater intention to purchase advertised products (Phua \& Kim, 2018). Hence, in a social media context, greater levels of product involvement will result in greater levels of intention to purchase. Specifically in fashion, product involvement with clothing was discovered to impact consumers' confidence in purchase decisions (O'Cass, 2004), supporting product involvement can lead to greater purchase intention. Hence, the following is proposed:

$\mathrm{H} 2$ : There is a positive relationship between product involvement and purchase intention 


\subsection{Fashion Brand Involvement and Online Brand Engagement}

Both involvement and engagement represent forms of interest; however, involvement is a cognitive state of mind, whereas engagement entails more of a behavioural aspect. "Thus, its heightened level of interest and caring suggests that involvement is an antecedent to engagement," (Vivek, Beatty, \& Morgan, 2012, p. 134). Recent studies also support the antecedent role involvement portrays in relation to engagement (Bowden, 2009; R. J. Brodie, L. D. Hollebeek, B. Juric, \& A. Ilic, 2011; van Doorn et al., 2010). In a social media context, social networking sites (SNS) not only facilitate information exchange about brands or products but also allow consumers to engage online in socializing experiences (Davis Mersey, Malthouse, \& Calder, 2010). Specifically, in fashion, Hollebeek et al. (2014) conceptualized fashion brand involvement as an antecedent of online brand engagement. As consumers express an increased fashion brand involvement, subsequently their desire to engage in and strengthen brand relationships increases too (J. O. Park, Hwang, \& Park, 2011). Smith et al. (2016)'s study found this to be true, mainly for consumers with a passion for fashion brands. Furthermore, scholars have discovered fashion involvement to impact a consumers' willingness to accept new clothing in a positive way (Rahman, Saleem, Akhtar, Ali, \& Khan, 2014). Hence, fashion brand involvement can be an antecedent of online brand engagement. Therefore, the following is proposed:

H3: There is a positive relationship between fashion brand involvement and online brand engagement. 


\subsection{Fashion Brand Involvement and Purchase Intention}

Consumers face countless decisions every day and brands are a key factor in simplifying the processes involved with forming a purchase decision, hence "brands are the most common rule of thumb in the contemporary marketplace," (Hutter et al., 2013, p. 343). Brands are also important because they enhance the desirability of a product and possess the power to enhance or deduct the perceived utility of a product (Kotler \& Gertner, 2002). Kotler and Gertner (2002) state brands differentiate products and communicate potential quality and value for consumers. Therefore, the greater the brand involvement, the greater the brand knowledge and confidence a consumer has to make present and future purchase decisions (Hutter et al., 2013; J. Kapferer, 2008; Keller, Parameswaran, \& Jacob, 2011). In an online context, promotional brand messages were found to influence a consumers' likelihood to purchase (Xie \& Lee, 2015). Moreover, studies show that consumers who relied on social media to gain brand information were more inclined to purchase (Olbrich \& Holsing, 2011; Trusov et al., 2009). This demonstrates the power of brand involvement to initiate and navigate consumers through the purchase decision process. Specifically, in a fashion brand context, a consumer's involvement in fashion had a significant influence on their fashion knowledge, which lead to greater confidence in purchase decisions and the conviction to choose the right brand (O'Cass, 2004) Hence, fashion brand involvement can equip consumers with the confidence required to make purchase decisions. In fashion, consumers also have a tendency to link brand symbols to self-concepts (DeeterSchmelz, Moore, \& Goebel, 2000), and desire brands that can enhance their own self-image (Zhang \& Kim, 2013). This is because purchasing these brands communicates a symbolic 
meaning to one's own self and close peers (O'Cass \& Lim, 2002). Therefore, increased involvement with fashion brands can result in an increased purchase intention of goods. Hence, the following is proposed:

H4: There is a positive relationship between fashion brand involvement and purchase intention.

\subsection{Online Brand Engagement and Purchase Intention}

Literature has linked the concept of engagement to many positive consequences (Bowden, 2009). One key consequence of engagement commonly discussed is purchase intention, as any purchase from a firm takes place only after a consumer "envisions the different ways in which a customer can interact or engage with the firm" (Kumar et al., 2010, p. 298).

Brand engagement, in particular, implies a brand that prevails in the mind of a consumer, and ties produced from multiple interactions with a brand have been demonstrated to lead to increased purchase intention (Bagozzi \& Dholakia, 2006). Hence, it is important to strengthen brand engagement so consumers will form a brand preference when selecting a product from a product category to purchase (Hutter et al., 2013). A relationship or connection with a brand also increases the probability of a brand qualifying into a consumer's consideration set; which represents a basket of brands that are evaluated during a consumer's decision to purchase (Chakravarti \& Janiszewski, 2003). Hutter et al. (2013)'s study discovered online brand engagement in a Facebook setting positively impacted brand awareness, WOM and purchase intention. Thus, online brand engagement raises the necessary brand awareness needed for consumers to form a willingness to purchase from a brand. Furthermore, the link between online 
brand engagement and purchase intent is also prominent in many consumer engagement studies (Appelbaum, 2001; Bowden, 2009; Erdoğmuş \& Tatar, 2015; Hollebeek, Glynn, \& Brodie, 2014; Hutter et al., 2013). Therefore, it is posited that:

H5: There is a positive relationship between online brand engagement and purchase intention

\subsection{Purchase Intention and Other Involvement}

Although altruism has been popularly explored in past research in a social or psychological context, it's relevance to purchase decisions has become a growing discussion in business literature (Powers \& Hopkins, 2006). Many scholars have agreed the key driver behind altruistic involvement is empathy; described as "other-oriented feelings congruent with the perceived welfare of another person" (Batson, Ahmad, \& Tsang, 2002, p. 436). In online settings, altruistic involvement is often expressed through empathetic motivations as consumers share knowledge with the aim to be helpful to others and enhance their welfare (Hsu \& Lin, 2008). Many eWOM studies have also noted consumers' opinion giving in online environments to be driven by altruistic involvement (Hennig-Thurau et al., 2004; Smith et al., 2007).

According to Babin et al.'s (2017) consumer value framework, altruistic involvement reflects a reaction which takes place post-purchase as the empathetic motivation to help others make a better purchase decision is based on a purchase experience. This means a purchase had to occur prior to sharing eWOM in order to guide and warn others in making better purchase decisions. Babin et al. (2017) state choice is a consumer's decision to purchase and occurs in the consumer decision-making process leading to purchase. Since consumers may delay or decline a purchase 
altogether, purchase intention closely measures a consumer's decision to purchase. Multiple studies have also demonstrated that asking consumers to forecast their future intention influences the probability that they will engage in that behavior (Chandon et al., 2005; Sherman, 1980; Spangenberg, 1997; Spangenberg \& Greenwald, 1999; Spangenberg et al., 2003). Hence, consumers who express strong purchase intentions are more likely purchase, consequently recommending products and brands to guide and protect other consumers from making poor purchase decisions and enhance their consumption experience. Therefore, it can be posited that:

H6: There is a positive relationship between purchase intention and altruistic involvement 


\section{$4 \quad$ Research Methodology}

In this chapter, research methodology, techniques used to collect data with respect to the research problem will be discussed. This section will begin by discussing the appropriate epistemological orientation chosen for this study, followed by a deliberation around the data

analysis method and software, sample size, data collection, and theoretical constructs. The proposed structural model will be empirically tested to examine the influence of product involvement, fashion brand involvement, other involvement, and online brand engagement on purchase intention in social media. Consequently, Partial Least Square Structural Equation Modeling (PLS-SEM) will be utilized to test the model in a more robust quantitative analysis (Hair Jr, Hult, Ringle, \& Sarstedt, 2016). By using PLS-SEM, the predictive capabilities behind the theoretical model can be empirically validated, as well as undercover underlying phenomena in our proposed relationships.

\subsection{Epistemological Orientation}

Epistemology is most popularly referred to as the philosophy of knowledge, and addresses the disposition, scope, and sources that comprise knowledge (DeRose, 2005). Social science is generally conducted against theoretical ideas, as well as ontological and epistemological assumptions. While ontological assumptions question the essence of social reality, epistemological assumptions question the nature of knowledge and the criteria for deciding when knowledge is reliable and acceptable (Blaikie, 2009). In general, there is no single 
universal research methodology appropriate for all research problems, instead, there are a variety of research methodologies that exist with its own strengths and weaknesses and such selection inevitably involves an advantage and disadvantage (Schulze, 2003). Selecting an appropriate research methodology is based on "the paradigm that guides the research activity, more specifically, beliefs about the nature of reality and humanity (ontology), the theory of knowledge that informs the research (epistemology), and how that knowledge may be gained (methodology)" (Tuli, 2010, p. 99). Thus, the epistemological orientation of a study is a key section discussed in any social science research.

In designing social science research, Blaikie (2010) outlines four classical research paradigms: positivism, critical rationalism, classical hermeneutics, and interpretivism, which represent the earliest attempts at applying or rejecting such research applications. Positivism, in particular is known to embody quantitative research (Blaikie, 2009), and is grounded upon the theorization that "there are universal laws that govern social events, and uncovering these laws enables researchers to describe, predict, and control social phenomena," (Tuli, 2010, p. 103). A researcher with a positivist orientation believes there is an objective real world that can be studied and described using quantitative methodologies (Bassey, 1995; Cohen, Manion, \& Morrison, 2000). Researchers who utilize this research orientation describe how variables interact with each other and produce outcomes in quantitative terms, often testing the accuracy of their assumptions through experimental studies (Schulze, 2003). Auguste Comte (1975), the father behind the foundations of sociology and positivism, claimed that social reality must be directly observed in an identical manner as the natural world, from which researchers can identify common laws of human behaviour (Gane, 2006). In positivism, the intention of social 
science is to reach the closest approximation of reality through the most objective method possible (Ulin, Robinson, \& Tolley, 2005). Knowledge is based on direct observations of a phenomenon, and our understanding about the nature of reality is based on the researchers' empirical findings and their interpretations (Denzin \& Lincoln, 2005; Neuman \& Kreuger, 2003). Through deductive reasoning, theoretical assumptions can be validated through hypothesis testing and can further justify the relationship between two constructs (Blaikie, 2009). There is a large emphasis on standardized tools such as questionnaires to explain human behaviour, and multivariate analyses and statistical predictions are the most commonly produced type of contributions in this research paradigm (Tuli, 2010). Also, research findings are usually communicated in numbers to present data in a quantitative format (Neuman \& Kreuger, 2003; Sarantakos, 2012).

A key implication of conducting a positivist research orientation is maintaining objectivity and neutrality, excluding the influence of personal bias in research (Carson, Gilmore, Perry, \& Gronhaug, 2001). In early examples of positivist thinking, philosopher Rene Descartes (1637) discussed the importance of researchers distancing themselves as an outsider from the sample under study to avoid any external influences that could corrupt the findings. "Basing evidence on direct observation and collecting it in an objective and unbiased way became key tenets of empirical [positivist] research," (Ritchie, Lewis, Nicholls, \& Ormston, 2013, p. 9). As a result, the positivist research methodology aims to be objective or detached, primarily focusing on measuring variables and testing hypotheses that connect to causal explanations (Tuli, 2010). 
Through a positivist research orientation, this research aims to collect empirical evidence to produce sound generalizations that predict consumer behaviour. This approach was adopted by conducting online questionnaires for study participants to complete. Positivist researchers emphasize the standardization of research tools and the need to remain detached from what they research to eliminate any potential bias originating from their own subjective selves. Thus, online questionnaires help avoid personal interaction with respondents and eliminates potential forms of researcher influence or bias. Through abstracting panel data, the identity of participants was protected, further following a positivist approach. The positivist orientation was also applied to form conclusions about social reality by deducing logic based on direct empirical observations, rather than deducing logic from abstract propositions. Such importance placed on maintaining objectivity, detachment from research participants, and scientific procedures to test hypotheses, supports the validity of findings from the positivist research orientation.

\subsection{Partial Least Squares Structural Equation Modeling - PLS-SEM}

When analyzing relationships in a structural model, Covariance-based SEM (CB-SEM) and PLS-SEM are two different methods most commonly employed. CB-SEM is described as a confirmatory approach, used when the primary objective of the study is to test, confirm, reject, or compare theories (Hair, Sarstedt, Ringle, \& Mena, 2012). In this method, error terms require additional specification, the structural model must demonstrate circular relationships, and the research conducted requires a global goodness-of-fit criterion (Hair Jr, Sarstedt, Ringle, \& Gudergan, 2017). On the other hand, PLS-SEM is more suitable for early-stage theory development and testing (Hair, Ringle, \& Sarstedt, 2013) when the primary objective of the 
study is to predict and explain relationships, directions, strengths, as well as key driving constructs (Hair et al., 2012). This method is applicable for both small and large sample sizes and is highly robust as long as missing values are below a reasonable level. PLS-SEM also handles constructs measured with both single and multi-item measures, incorporates both reflective and formative measurement models, and minimizes the amount of unexplained variances (Hair Jr et al., 2017). Hence, PLS-SEM is noted for greater statistical power and the probability to detect a significant relationship more effectively than CB-SEM (Hair, Ringle, \& Sarstedt, 2011, p. 143).

Studying purchase patterns can help us better understand why certain consumers are more involved and engaged than others and help firms create more effective campaigns. However, despite the increasing scholarly attention regarding commercial activities conducted on social media, studies mainly consist of exploratory data, demonstrating a lack of empirical research exists (Bai, Yao, \& Dou, 2015). To address this absence, this paper will adopt SmartPLS (Ringle, Wende, \& Becker, 2015), a quantitative data analysis software, to conduct the partial least squares structural equation modeling (PLS-SEM) method. By adopting this quantitative data analysis methodology, this paper aims to illustrate how model building can assist in understanding relationships between constructs in a social media environment. To conduct the PLS-SEM data analysis, there are a variety of software programs researchers can utilize. PLSGraph is an example of one of the early PLS-SEM software programs favoured by many (Chin, 2003). Its graphical interface and improved user-friendliness are said to be an extension of LVPLS, which was said to be the first software program introduced by Lohmoller (1987) to the realm of PLS-SEM. The latter required the use of a text editor to enter commands, whereas the 
former was more practical, convenient, and easy to operate. However, LVPLS, PLS-Graph, and other early software programs such as SPAD-PLS and VisualPLS (Fu, 2006) and have become outdated, not receiving any upgrade for years (Hair Jr et al., 2017). This poses as a disadvantage for researchers as obsolete software programs lack the capacity to reflect technological and statistical changes in recent years. Fortunately, the widespread adoption of PLS-SEM in various disciplines has brought forth many updated, user-friendly software programs for researchers to adopt, including: XLSTAT's PLSPM package, Adanco (J Henseler \& Dijkstra, 2015), PLS-GUI (Hubona, 2015), WarpPLS (Kock, 2015), and SmartPLS (Ringle et al., 2015). In this study, SmartPLS will be adopted to analyze the data collected and there are key reasons to justify this decision. First, according to Hair et al. (2017) SmartPLS is the most comprehensive and advanced program to date, with continuous improvements being made as seen evident with its recent release and upgraded features found in version 3 in 2015. Also, Smith et al. (2016) used Smart PLS 3 to analyze the data as it has a graphical user interface that allows users to estimate the PLS path model. Therefore, SmartPLS 3.2.8 will be employed to test the data and the rules for assessment will be applied according to Hair et al. (2017).

While selecting a suitable statistical analysis poses a challenge for business management and social sciences researchers (Ramayah, Ignatius, Leen, \& Chiun, 2014), PLS-SEM provides many advantages in marketing and consumer behaviour studies (Jörg Henseler, 2010; Reinartz, Haenlein, \& Henseler, 2009; Sarstedt, 2008). As discussed earlier, PLS-SEM is an effective segmentation tool that can uncover and understand the underlying phenomena found in the data (Becker, Rai, Ringle, \& Völckner, 2013). This prediction-oriented approach is the most appropriate data reduction and data analysis method for this study as it can be utilized to 
investigate the relationships between constructs such as involvement, brand engagement, and purchase intent (Hair Jr et al., 2016). Additionally, PLS-SEM is suitable to explain complex relationships due to its ability to evaluate cause-effect relationships (Gudergan, Ringle, Wende, \& Will, 2008), thus researchers can better analyze mediating relationships between and further increase their knowledge. Michon et al. (2008) also supports the use of the structural equation modeling approach and further applies it in a retail shopping context to explore the relationships between different constructs. Furthermore, Rahman et al. (2016) have also pointed out the usefulness of PLS-SEM in developing and testing theories in fashion focused research. Through the PLS-SEM method, the proposed model for purchase intent will be based on Smith et al. (2016)'s theoretical model of purchase intention on social networking sites and be tested to investigate the impact of various involvement and engagement constructs. Acknowledging the significance of the features mentioned above, PLS-SEM is the data analysis method adopted in this study.

\subsection{Sample \& Data Collection}

This data was collected from a database generated from a questionnaire that was applied to previous research done by Smith et al. (2016) and was utilized to report on consumption levels and shopping behaviour of jeans on social media platforms. Smith et al. (2016) hired Qualtrics, a marketing research firm, to recruit, pre-screen, and administer the online questionnaire to panelists near the end of January 2015. After cleansing the data, the final sample consisted of 799 respondents who were buyers of jeans that possessed various social media behaviours and fashion sense. This study focused on assessments to better understand product-related consumer 
behaviour, thus the data collection research strategy most appropriate for this study were the use of questionnaires as this method allowed large amounts of product and consumer-related data to be measured and collected. As semi-natural settings involves "asking individuals to report on their own activities, attitudes, motives, or on social processes and institutionalized practices, the main kinds of data that can be collected in these studies include: demographic characteristics, orientations to the world, and reported behaviour" (Blaikie, 2009, p. 166). Therefore, by conducting surveys in a semi-natural setting through self-administered and structured questionnaires, re-occurring themes and patterns can be analyzed to further describe the phenomenon. The participants of this study were situated in four different provinces (British Columbia, Alberta, Ontario, Quebec) that represent major retail markets in Canada. Since this study required human subjects like much of all social science research, it was mandatory to seek approval from the Research Ethics Board (REB). This board guarantees that this study will be conducted through voluntary participation with the informed consent of research participants to ensure research is conducted with integrity. Ryerson University's REB approved the data collection for this research in early January 2015.

According to the sample characteristics displayed in Table 1 below, approximately $60.8 \%$ of the panelists were female and $39.2 \%$ were male, with $39.7 \%$ of all panelists residing primarily in Ontario. Although $25.2 \%$ of the panelists were between the age of 30 years old, this data captured multiple generational cohorts including: Generation Z, Generation Y, Generation X, and Baby Boomers as the panelists were reported to be as young as 17 to as old as age 70. In terms of social media usage, Facebook, YouTube, and Twitter are the top three social media platforms that these panelists were found to be the most active on. Considering Facebook, 
Youtube, and Twitter are social media platforms that have been around the longest and were established over a decade ago around 2005-2006 (Farhi, 2009; Roblyer, McDaniel, Webb, Herman, \& Witty, 2010; Shifman, 2012), these platforms have the most activity compared to the newer social media platforms such as Instagram and Vine which were launched in 2010 and 2013 respectively (Lipschultz, 2014; Silva, Vaz de Melo, Almeida, Salles, \& Loureiro, 2013). The data also shows that approximately $36.9 \%$ of the panelists purchase jeans a few times a year, with $21.4 \%$ of the panelists purchasing jeans every $2-3$ months. This could indicate $21.4 \%$ of the panelists are highly involved with jeans and express greater levels of interest towards fashion trends. The majority of panelists also consider at least 2-3 brands before committing to purchase jeans. This shows brands play an important role in the purchase decision-making process as many alternatives exist. Table 1 further illustrates this data.

\begin{tabular}{|c|c|c|c|}
\hline Measure & Items & Frequency & Percent \\
\hline \multirow{2}{*}{ Gender } & Female & 486 & 60.8 \\
\hline & Male & 313 & 39.2 \\
\hline \multirow{6}{*}{ Age } & $17-20$ & 67 & 8.4 \\
\hline & $21-30$ & 201 & 25.2 \\
\hline & $31-40$ & 139 & 17.4 \\
\hline & $41-50$ & 135 & 16.9 \\
\hline & $51-60$ & 154 & 19.3 \\
\hline & $61-70$ & 103 & 12.9 \\
\hline \multirow{4}{*}{ Canadian Province } & British Columbia & 215 & 26.9 \\
\hline & Alberta & 135 & 16.9 \\
\hline & Ontario & 317 & 39.7 \\
\hline & Quebec & 132 & 16.5 \\
\hline \multirow{7}{*}{ Social Media Usage } & Facebook & 489 & 61.2 \\
\hline & Youtube & 255 & 31.9 \\
\hline & Twitter & 202 & 25.3 \\
\hline & Pinterest & 186 & 23.3 \\
\hline & Google+ & 182 & 22.8 \\
\hline & Instagram & 161 & 20.2 \\
\hline & Vine & 27 & 3.4 \\
\hline \multirow{7}{*}{ Purchase Frequency of Jeans } & Weekly & 5 & 0.6 \\
\hline & A few times a month & 15 & 1.9 \\
\hline & Monthly & 40 & 5.0 \\
\hline & Every 2-3 months & 171 & 21.4 \\
\hline & A few times a year & 295 & 36.9 \\
\hline & Once a year & 161 & 20.2 \\
\hline & Less than once a year & 112 & 14.0 \\
\hline \multirow{7}{*}{$\begin{array}{c}\text { Number of Brands Considered } \\
\text { Before Purchasing Jeans }\end{array}$} & 1 & 173 & 21.7 \\
\hline & 2 & 300 & 37.5 \\
\hline & 3 & 219 & 27.4 \\
\hline & 4 & 62 & 7.8 \\
\hline & 5 & 22 & 2.8 \\
\hline & 6 & 6 & 0.8 \\
\hline & 7 or More & 17 & 2.1 \\
\hline
\end{tabular}

Table 1: Sample Characteristics 
When determining the sample size, many factors were taken into consideration in deciding the appropriate sample size to measure. Scholars advise "as sample size increases, sampling error decreases and sample reliability increases" (Blaikie, 2009, p. 185). As a large sample size is utilized in this study, the characteristics of this population will likely be heterogeneous, making it an appropriate sample size to accurately capture consumer behaviour. Additionally, this data was collected following a cross-sectional study as it best captures the present "aspects of social life including: demographic characteristics, individual attitudes, values, beliefs and behaviour, and social interaction..." (Blaikie, 2009, p. 201). Data was cleansed by using screening questions to ensure the correct participants were responding to the questions and filter questions to remove participants who did not accurately answer questions, reducing the likelihood of skewed data. The questionnaire was also designed to avoid common method bias by using attention filters, variation of types and endpoints of scales, randomization of statements within questions, and randomization of blocks of questions (D. Smith, Hernández-García, Agudo Peregrina, \& Hair Jr, 2016).

The questionnaire responses were recorded in pre-coded categories and was designed to include attention filters, endpoints of scales, randomization of statements within questions, and randomization of blocks of questions to prevent common method bias. The key constructs and measurement scales include:

Shopping Habits: Attitudes and behaviour towards shopping measured using ordinal scales ranking the level of agreement or disagreement to a list of shopping related statements. Adopted from Babin et al. (2014). 
Social Media \& Brand Community Involvement/Engagement: Attitudes and participation levels measured through ordinal scales ranking the level of agreement or disagreement. Adopted from Wolny and Mueller (2013).

Purchase Intent: Commitment to purchase triggered by factors of social networking sites and related communities are assessed through ordinal scales of very unlikely to very likely. Adopted from Campbell et al. (2014).

Product Involvement: Uncover which product involvement predispositions trigger online engagement and purchases by using ordinal scales of strongly disagree to strongly agree. Adopted from Wolny and Mueller (2013).

Other Involvement: Reveal which altruistic motives trigger engagement through participating in eWOM using ordinal scales of strongly disagree to strongly agree. Adopted from Wolny and Mueller (2013).

Fashion Brand Involvement: Examine how influential fashion brands are amongst consumers through ordinal scales of strongly disagree to strongly agree. Adopted from Wolny and Mueller (2013).

Online Brand Engagement: Analyze the level of brand engagement consumers experience in online settings by utilizing ordinal scales of strongly disagree to strongly agree. Adopted from Campbell et al. (2014).

For further insight on measurement scales and their theoretical origins that were used in this study, a detailed list of data construct descriptions listed in alphabetical order can be found in Appendix A2. 


\subsubsection{Sample Size X Theoretical Model}

The minimum sample size ensures the results of the PLS-SEM analysis will have adequate statistical power to produce significant results. To confirm the data meets the minimum sample size requirements, the data was tested against the 10 times rule to ensure studies are conducted using an efficient sample size. According to Barclay et al. (1995), the sample size should meet at least one of the two mandatory requirements. The first requirement necessitates the sample size to be 10 times the largest number of formative indicators used to measure a single construct (Hair Jr et al., 2016). Referring to the model proposed in this study, the largest number of formative indicators is Fashion Brand Involvement with 11 indicators; thus, according to this condition a sample size larger than 110 respondents is required $(11 * 10=100<799)$. The second requirement necessitates the sample size to be 10 times the largest number of structural paths aimed at a an individual construct (Hair Jr et al., 2016). Referring to the model proposed in this study, the largest number of structural paths directed to a single construct is 3 ; hence, in this case, a sample larger than 30 respondents is required $(3 * 10=30<799)$. With the sample size of 799 respondents, both conditions are met and accepted as an adequate sample size for this study.

While the 10 times rule acts as a criterion to determine the minimum sample size, the required sample size should be established through further analyses. Cohen's (1992) rules for assessment is often relied upon by researchers as it features OLS regression which is the basis of

PLS-SEM (Hair Jr et al., 2016). The rules of assessment demonstrate the structural model quality 
can be validated by the maximum number of arrows pointing at a single construct, also referred to as the number of independent variables. In Hair et al. (2016), a criterion for an acceptable sample size in PLS-SEM for a statistical power of 80\% is adapted from Cohen's (1992): A Power Primer (Hair Jr et al., 2016, p. 26). Using this table as a guideline, after assessing the proposed model, one arrow is removed with 10 arrows remaining, therefore considering the sample of 799 respondents, it can be concluded that the minimum sample requirements to test the model have been met, as 212 observations are required to detect $\mathrm{R}^{2}$ values of around 0.10 at a significance level of $1 \%$ and a power level of $80 \%$ (Cohen, 1992). As the sample size used in this study is considerably larger than 212 as per Cohen's (1992) rules of assessment, this sample size will yield significant contributions to research.

\subsection{Data Analysis Method}

Prior to selecting a suitable data analysis method, it is important to distinguish between normal and non-normal distributions in structural equation modeling (SEM). Hence, all indicator variables found in the model with a significance at the $p=0.000$ level was statistically tested against the Kolmogorov-Smirnov and Shapiro-Wilks tests, seen in Table 2 below. These tests help researchers assess normality by comparing the data to a normal distribution with the same mean and standard deviation as in the sample (Sarstedt \& Mooi, 2014). As PLS-SEM is a nonparametric statistical method, it implies the data to is not normally distributed (Hair Jr et al., 2016). However, it is important to verify that the data is not considered extremely non-normal as such data can inflate standard errors during bootstrapping, decreasing the significance of certain relationships (J. F. Hair, C. M. Ringle, \& M. Sarstedt, 2011; Reinartz et al., 2009). PLS-SEM is 
also the preferred data analysis method when the structural model contains formative constructs (J. F. Hair et al., 2011; Hair Jr et al., 2016), hence unlike CB-SEM, the PLS-SEM method can be applied to various research settings as it easily accounts for reflective and formative constructs more efficiently (Hair Jr et al., 2017). 
Tests of Normality

\begin{tabular}{|c|c|c|c|c|c|c|c|}
\hline \multirow[t]{2}{*}{ Indicator } & & \multicolumn{3}{|c|}{ Kolmogorov-Smirnov $^{a}$} & \multicolumn{3}{|c|}{ Shapiro-Wilk } \\
\hline & & Statistic & $d f$ & Sig. & Statistic & df & Sig. \\
\hline PI1 & Q33_1VirtPlatJoy & .185 & 799 & .000 & .886 & 799 & .000 \\
\hline PI2 & Q33_2VirtPlatDisapp & .172 & 799 & .000 & .887 & 799 & .000 \\
\hline PI3 & Q33_3VirtPlatBuySucc & .184 & 799 & .000 & .886 & 799 & .000 \\
\hline PI4 & Q33_4VirtPlatBuyFail & .206 & 799 & .000 & .871 & 799 & .000 \\
\hline OBE1 & Q34_1TalkBrSN & .228 & 799 & .000 & .833 & 799 & .000 \\
\hline OBE2 & Q34_2InterstBrSN & .163 & 799 & .000 & .910 & 799 & .000 \\
\hline OBE3 & $\begin{array}{l}\text { Q34_3InterestCommBrS } \\
\mathrm{N}\end{array}$ & .203 & 799 & .000 & .858 & 799 & .000 \\
\hline OBE4 & Q34_4AccepCommBrSN & .130 & 799 & .000 & .918 & 799 & .000 \\
\hline OBE5 & Q34_5PrideAffilSN & .221 & 799 & .000 & .854 & 799 & .000 \\
\hline OBE6 & Q34_6BrowseSN & .208 & 799 & .000 & .859 & 799 & .000 \\
\hline OBE7 & Q34_7FollowBr & .225 & 799 & .000 & .829 & 799 & .000 \\
\hline PR1 & Q38_1PurchAdvSN & .212 & 799 & .000 & .877 & 799 & .000 \\
\hline PR2 & Q38_2PurchConsSN & .192 & 799 & .000 & .892 & 799 & .000 \\
\hline PR3 & $\begin{array}{l}\text { Q38_3PurchSNPriceApp } \\
\text { eal }\end{array}$ & .171 & 799 & .000 & .909 & 799 & .000 \\
\hline PR4 & Q38_4PurchSNDeliv & .204 & 799 & .000 & .880 & 799 & .000 \\
\hline PR5 & Q38_5PurchSNTrustBr & .170 & 799 & .000 & .908 & 799 & .000 \\
\hline PR6 & Q38_6PurchSNNewProd & .202 & 799 & .000 & .883 & 799 & .000 \\
\hline OI1 & Q39_1WriteVirHelpOth & .166 & 799 & .000 & .893 & 799 & .000 \\
\hline OI2 & Q39_2WriteVirWarnOth & .157 & 799 & .000 & .893 & 799 & .000 \\
\hline OI3 & Q39_3WriteVirGiveOpp & .171 & 799 & .000 & .895 & 799 & .000 \\
\hline OI4 & $\begin{array}{l}\text { Q39_4WriteVirExposeBa } \\
\text { dBeh }\end{array}$ & .151 & 799 & .000 & .898 & 799 & .000 \\
\hline FBI1 & Q31_01Trust & .127 & 799 & .000 & .953 & 799 & .000 \\
\hline FBI2 & Q31_02Tweets & .277 & 799 & .000 & .774 & 799 & .000 \\
\hline FBI3 & Q31_03Posts & .235 & 799 & .000 & .815 & 799 & .000 \\
\hline FBI4 & Q31_04IdentifyWBr & .147 & 799 & .000 & .918 & 799 & .000 \\
\hline FBI5 & Q31_05BuyRtBr & .190 & 799 & .000 & .871 & 799 & .000 \\
\hline FBI6 & Q31_06FsnBloggers & .286 & 799 & .000 & .752 & 799 & .000 \\
\hline FBI7 & Q31_07Posts & .254 & 799 & .000 & .801 & 799 & .000 \\
\hline FBI8 & Q31_08Pins & .286 & 799 & .000 & .758 & 799 & .000 \\
\hline FBI9 & Q31_09TrustRetail & .113 & 799 & .000 & .954 & 799 & .000 \\
\hline FBI10 & Q31_10RetTweet & .275 & 799 & .000 & .757 & 799 & .000 \\
\hline FBI11 & Q31_11EffortRtBr & .162 & 799 & .000 & .899 & 799 & .000 \\
\hline
\end{tabular}

Table 2: Normality Tests: Kolmogorov-Smirnov and Shapiro-Wilks

(Please refer to Appendix A2 for a detailed description of each indicator) 


\subsubsection{Reflective Constructs}

Two key methods have been established to measure constructs. Based upon the classical test theory, one approach is defined as the reflective measurement model. In this approach, the direction of the causality point from the construct to the indicator variables, indicating the direction of causality is from the construct to the indicators and any changes in the construct are theorized to create changes in the indicators as well (Fornell \& Bookstein, 1982). Thus, the phenomenon is influenced by the construct and the indicators are expected to be highly correlated. Common examples of appropriate reflective constructs used in marketing and consumer behaviour research include psychological based constructs such as attitudes and purchase intention (Jarvis, MacKenzie, \& Podsakoff, 2003). Attitudes are typically regarded as a favorable or unfavorable predisposition towards an object and are popularly measured on multiitem scales with endpoints such as good/bad, like/dislike, and favorable/unfavorable; while purchase intentions are generally measured using subjective approximations of how likely/unlikely, probable/improbable, and possible/impossible future purchases are assumed to be (MacKenzie, Lutz, \& Belch, 1986). From the proposed structural model, a total of four reflective constructs: product involvement, online brand engagement, purchase intention, and other involvement are discussed in this chapter.

After the decision rules for choosing an appropriate measurement model established by Hair et al. (2017, p. 52) was applied, the first reflective construct identified in the proposed structural model is product involvement. Using the scales derived from Wolny and Mueller (2013), these scholars cite their measurement of product involvement was adopted from Hennig- 
Thurau (2004) and O'Cass (2004), who proposed product involvement leads to measures such as expressing joy/disappointment about a product and feeling good when telling others about buying successes/ failures. As the indicators for product involvement include joy, disappointment, success, failure, it is a reflective construct due to its favourable and unfavourable sentiments. As this construct is a predisposition, it is measured in the questionnaire using multi-item scales with endpoints like strongly disagree to strongly disagree.

The second reflective construct identified using the rules for selecting an appropriate measurement model by Hair et al. (2017, p. 52), is online brand engagement. Using the scales derived from Campbell et al. (2014), these scholars cite their measurement of online brand engagement was adopted from Keller's (2001) customer-based brand equity study; including measures such as: talking about brands that are advertised on social networking sites, learning more about brands/organizations that are present online, expressing interest in receiving communications from a brand via social networking sites, accepting of communications from brands provided they seek permission, feeling proud to have others know which brands one affiliates with via social networking sites, browsing through social networking related to brands, and compared to other people, closely following news about brands. As these indicators contain probable and improbable sentiments, it portrays qualities of a reflective construct. This construct is also measured in the questionnaire using multi-item scales with strongly disagree to strongly disagree as endpoints. 
The third reflective construct recognized using the rules for selecting a suitable measurement model by Hair et al. (2017, p. 52) is purchase intention. The scales for this construct was derived from Campbell et al. (2014) who developed a scale to measure consumers' willingness to purchase from products that they see: advertised on social networking sites, other consumers talking about on social networking sites, on social networking sites if the price is appealing, on social networking sites if the delivery period is satisfactory, on social networking sites if it is a brand they know and trust, and on social networking sites if it is a new and exciting product. As the indicators for online brand engagement include likely and unlikely sentiments, it is measured in the questionnaire using multi-item scales with such endpoints; portraying qualities of a reflective construct.

Finally, altruistic involvement is the last reflective construct identified using the rules for selecting a suitable measurement model by Hair et al. (2017, p. 52). The scales for this construct was derived from Wolny and Mueller (2013) who state they adopted their measurement from Hennig-Thurau's (2004) eWOM studies to include measures to track consumers' motives behind altruistic involvement such as: wanting to help/warn others with my positive/negative experiences with brands, wanting to give others the opportunity to buy nice products, and wanting to expose brands that behave badly. As the indicators for altruistic involvement include help, warn, give, expose, it is a reflective construct due to its favourable and unfavorable sentiments and is measured in the questionnaire using multi-item scales with endpoints such as strongly disagree to strongly disagree. 


\subsubsection{Formative Constructs}

As discussed earlier, the reflective measurement model is one of the two key ways researchers measure constructs. In contrast to the reflective measurement model, the formative measurement model does not assume that casual orientation can occur from a single construct to its measures. In this model it is assumed that the indicators cause the construct through linear combinations (Diamantopoulos \& Winklhofer, 2001), as the direction of causality point from the indicators to the construct; demonstrating the indicators as a group equally determine the conceptual and empirical meaning of the construct (Jarvis et al., 2003). Unlike reflective indicators where a change in the construct will cause a change in every indicators, formative indicators are not interchangeable in nature, thus a change in a single indicator can result in a change in the entire construct (Edwards \& Bagozzi, 2000). Hence, each indicator represents a unique feature of the formative construct. Since the indicators jointly determine the meaning of the construct, adding or dropping an indicator can significantly impact the conceptual the nature of the construct and create serious implications (Coltman, Devinney, Midgley, \& Venaik, 2008; Jarvis et al., 2003). As a result, researchers are highly encouraged to include an extensive coverage of indicators to ensure that the conceptual nature of the construct is accurately represented (Hair Jr et al., 2016).

It is important to note there are two key indicators: composite and causal. Composite indicators are combined in a linear way to form the construct, whereas causal indicators as the name implies, are the cause of the construct (Bollen \& Bauldry, 2011). The slight difference between both types of indicators has important consequences during the modeling of the 
construct, as causal indicators cannot fully capture every aspect of the phenomenon (Diamantopoulos \& Winklhofer, 2001). Thus, causal indicators assume that a construct can be measured using a set of indicators along with an error term; which is used to recognize all other causes of the construct that may not be included in the structural model (Diamantopoulos, 2006). On the other hand, composite indicators do not make such assumptions, but rather view measurement as an approximation of a theoretical concept. In social sciences research, composite indicators are preferred over causal indicators because viewing measurement as an approximation is seen as more realistic (Rigdon, 2014). In addition, the PLS-SEM algorithm is based solely on the concept of composite indicators (Hair Jr et al., 2017). Therefore, in line with the PLS-SEM methodology applied in this study, formative indicators are referred to as composite indicators. Examples of appropriate formative constructs used in marketing and consumer behaviour research mainly consist of managerial based constructs, such as market dynamism, noncoercive power, job performance, strategic performance, unfair trade practices, output controls, status, competitive and market intelligence (Jarvis et al., 2003).

Fashion brand involvement is the only formative construct identified using the rules for selecting a suitable measurement model by Hair et al. (2017, p. 52). The scales for this construct were derived from Wolny and Mueller (2013) who state they adopted their measurement from Zaichkowsky's (1985) and Beatty and Kahle's (1988) brand commitment studies to include eleven formative indicators that best represent fashion brand involvement. As the indicators for this construct signify different characteristics of the construct (i.e. 'tweets by fashion brands influence my buying behaviour' versus 'I can identify with people wearing the same brands as me'); these indicators are not interchangeable, hence are formative by nature. 


\section{$5 \quad$ Data Analysis \& Results}

\subsection{Assessment of Reflective Measurement Models}

To test the validity of the reflective measurement model, the internal consistency reliability, convergent validity, and discriminant validity were assessed as per Hair et al.'s (2017) rules for assessment. These tests were run after setting the PLS algorithm to a maximum iteration of 300 and a stop criterion of 7, as recommended by Hair et al. (2017). First, Cronbach's Alpha was analyzed to provide the level of internal consistency reliability for each reflective construct based on the intercorrelations of the observed indicator variables. Commonly accepted values range between 0.60 to 0.90 for exploratory and advanced stages of research. Product involvement, online brand engagement, purchase intention, and other involvement surpassed a level of 0.70 on this criterion. However, all four reflective constructs revealed values above 0.90 for composite reliability, as seen in Appendix A3. Values above 0.90 are not satisfactory because it demonstrates the indicators are capturing the same aspect of the phenomenon. This may occur when questions are slightly rephrased using semantically redundant items, thus cannot be counted as a reliable indicator of the construct. In this case, Hair et al. (2017) recommends that scales undergo further testing due to possible semantic similarities. Hence, a reliability analysis on SPSS was conducted to further statistically verify the reliability of the indicators. In Appendix A4, the values in the column titled Cronbach's Alpha If Item Deleted shows the value of the overall Cronbach's Alpha if that item was deleted. Hence, according to researchers these values reflect a change in Cronbach's Alpha if an item was removed (Field, 2009). In Appendix A5, the computed average of Cronbach's alpha is displayed as 0.970. None of the values in Appendix A4 
show a dramatic change to the average Cronbach's alpha if the item was deleted. Therefore, all items can be said to reflect a reasonable degree of reliability and are kept in the model.

Next, the outer loadings of the indicator variables were tested through the outer loading relevance test. According to Hair et al.'s (2017) rules for assessment, outer loadings should present values of 0.708 or higher to validate indicator reliability. According to the results displayed in Appendix A6, all variables had values above this threshold, demonstrating that the indicators are conceptually distinct enough from the others, hence do not need to be removed from the model. In addition to the outer loading relevance test, the average variance extracted (AVE) was also evaluated to test the convergent validity. Convergent validity is the degree to which an indicator correlates positively with alternative indicators of the same construct (Hair Jr et al., 2017). At minimum, values are required to equal 0.50 to confirm convergent validity. As seen in Appendix A3, all AVE values surpassed 0.70 for all the reflective constructs in the model, confirming convergent validity.

Finally, discriminant validity was tested to verify the extent to which a construct is distinct from all other constructs. Researchers utilize this test to confirm the uniqueness of a construct in reflecting a phenomenon that isn't recognized by other constructs in the model. This test was applied using a three-step analysis, including: cross-loadings, Fornell-Larcker criterion, and the heterotrait-monotrait ratio (HTMT). The results from the first step, the analysis of crossloadings is displayed in Appendix A7. To verify discriminant validity, the indicators' outer loading on its associated construct should be greater than any of its cross-loadings on other 
constructs (Hair Jr et al., 2017). This result was found to be true for product involvement, online brand engagement, purchase intention, and other involvement as seen in Appendix A7, demonstrating discriminant validity. Next, following the steps outlined by Hair et al. 2017, the Fornell-Larcker criterion test was applied. The square root of all AVE values was greater than its correlation with any other construct as seen in Appendix A8, indicating results that are traditionally believed to demonstrate discriminant validity. However, recently scholars have argued the lack of reliability found in cross-loadings and the Fornell-Larcker criterion in confirming discriminant validity (Jörg Henseler, Ringle, \& Sarstedt, 2015). Hence, HTMT was proposed as the final and most reliable step in determining discriminant validity. HTMT is the mean of all correlations of indicators across constructs, and measures the true correlation between two constructs, as known as the disattenuated correlation (Hair Jr et al., 2017). A confidence interval that contains the value 1 indicates a lack of discriminant validity. After running the bootstrapping procedure, the results displayed in Appendix A9 show the value 1 was outside the interval's range, implying that these constructs are indeed empirically distinct. A summary of the analysis for the reflective measurement models is included in Appendix A10.

\subsection{Assessment of Formative Measurement Models}

To test the validity of the formative measurement model, the convergent validity, collinearity, and the significance and relevance of the formative indicators were assessed as per Hair et al.'s (2017) rules for assessment. First, the convergent validity of the formative measurement model was tested. To assess convergent validity, a redundancy analysis was performed on fashion brand involvement. The formatively measured construct was used as an 
exogenous latent variable to predict the same construct operationalized by reflective indicators. According to Hair et al.'s (2017) rules for assessment, intervals above 0.70 are recommended. The path coefficient for fashion brand involvement formative to fashion brand involvement reflexive was 0.85 as shown in Appendix A11, meeting the requirements per Hair et al. (2017).

Next, collinearity in the formative model was assessed. Unlike the interchangeability of reflective measures, high correlations between formative measures are not supported. In a situation where, formative measures are highly correlated, collinearity occurs and proves to be challenging for researchers because they can impact the statistical significance of the model. Thus, to assess for collinearity, a variance inflation factor (VIF) analysis was performed to detect the extent to which the standard error has been increased due to possible collinearity. Hair et al. (2017) advise a VIF value of 5 or greater indicates the presence of a collinearity issue. In this study the results from the VIF analysis are shown in Appendix A12, where one indicator, FBI7 displays a VIF value of 5.668 , meaning $80 \%$ of its variance is accounted for by the remaining formative indicators. When taking a further look, Appendix A2 lists FBI7 indicates "posts in social media by retailers influence my buying behaviour". When comparing similarities to other indicators, this indicator is almost identical to FBI3; "posts in social media by fashion brands influence my buying behaviour". Hence, due to its high collinearity with other indicators, FBI7 was removed from the analysis.

Finally, the last step of confirming the significance and relevance of the formative indicators was conducted. A bootstrapping procedure was performed to test the values of outer 
weights as they represent the significance and relative importance of construct (Hair Jr et al., 2017). Following the rules of assessment, the bootstrapping settings were set to 5,000 bootstrap samples, 300 observations, and the "no sign change" option. Five indicators (FBI1, FBI2, FBI5, FBI6, and FBI9) presented values greater than 0.05, implying a lack of significant outer weight at a significance level of 5\%. In this case, when an indicator's outer weight is not significant it is not relatively important. However, Hair et al. (2017) advises if its outer loading displays large values greater than 0.50 , then it should remain in the model as it is interpreted as absolutely important. Thus, the outer loadings for these indicators were assessed to identify possible absolute contribution. Based on the results, all five indicators presented values above 0.50, and were therefore retained in the model for meeting the recommended criteria for size and significance. A summary of the analysis for the formative measurement model is displayed in Appendix A13.

\subsection{Assessment of the Structural Model}

After confirming the validity and reliability of the reflective and formative measurement models, the next step is to assess the structural model's predictive capabilities and relationships between constructs. The procedure for analyzing the structural model involves a few key steps: assessing the structural model for collinearity issues, assessing the significance and relevance of the structural model relationships, assessing the level of $\mathrm{R}^{2}$, assessing the $\mathrm{f}^{2}$ effect size, and assessing the predictive relevance $\mathrm{Q}^{2}$. The first step is to confirm the absence of collinearity issues. Similar to the evaluation of the formative measurement models, a VIF analysis was conducted for each predictor construct in the model (product involvement, fashion brand involvement, online brand engagement, and purchase intention). As shown in Table 3, the largest 
VIF value in the proposed model was 2.950, well below Hair's et al. (2017) threshold value of 5. Therefore, validating the absence of collinearity issues in this model.

\begin{tabular}{|l|r|r|r|r|r|}
\hline \multicolumn{7}{|c|}{ Collinearity Analysis (VIFs) } \\
\hline & $\begin{array}{c}\text { Product } \\
\text { Involvement }\end{array}$ & $\begin{array}{c}\text { Fashion Brand } \\
\text { Involvement }\end{array}$ & $\begin{array}{c}\text { Online } \\
\text { Brand } \\
\text { Engagement }\end{array}$ & $\begin{array}{c}\text { Purchase } \\
\text { Intention }\end{array}$ & $\begin{array}{c}\text { Other } \\
\text { Involvement }\end{array}$ \\
\hline Product Involvement & & 1.000 & & 1.726 & \\
\hline Fashion Brand Involvement & & & 1.000 & 2.502 & \\
\hline Online Brand Engagement & & & & 2.950 & \\
\hline Purchase Intention & & & & & \\
\hline Other Involvement & & & & & 1.000 \\
\hline
\end{tabular}

Table 3: Results from collinearity analysis (VIFs)

Next, the significance and relevance of the path coefficients in the structural model was examined. These path coefficients represent hypothesized relationships in the proposed model and generally carry standardized values between -1 and +1 . According to Hair et al. (2017), path coefficients close to +1 or -1 represent strong relationships that are statistically significant, whereas path coefficients with values closer to 0 represent weaker relationships with lower significance. By running a bootstrapping procedure in same settings conducted for the formative measurement model (5,000 bootstrap samples, 300 observations, and the "no sign change" option), the results indicated by the standard error can determine the significance of the hypothesized relationships. It is important to note that researchers in the marketing discipline assume a significance of $5 \%$, therefore the p-value must be less than 0.05 to conclude the relationship under consideration is significant at a 5\% level (Hair Jr et al., 2017). Table 4 provides a summary of the significance testing results for the proposed model. 


\begin{tabular}{|l|r|r|r|r|l|l|}
\hline \multicolumn{2}{|l|}{ Significance Testing Results of The Structural Model Path Coefficients } \\
\hline & $\begin{array}{c}\text { Path } \\
\text { Coefficients }\end{array}$ & t Value & $p$ Value & $\begin{array}{c}\text { 95\% } \\
\text { Confidence } \\
\text { Intervals }\end{array}$ & $\begin{array}{c}\text { Significance* } \\
(\mathrm{p}<0.05) ?\end{array}$ & $\begin{array}{c}\text { Hypothesis } \\
\text { Number }\end{array}$ \\
\hline PI-FBI & 0.554 & 21.783 & 0.000 & {$[0.498,0.597]$} & Yes & H1 \\
\hline PI-PURI & 0.128 & 4.112 & 0.000 & {$[0.069,0.192]$} & Yes & H2 \\
\hline FBI-OBE & 0.771 & 43.442 & 0.000 & {$[0.732,0.802]$} & Yes & H3 \\
\hline FBI-PURI & 0.321 & 7.625 & 0.000 & {$[0.235,0.399]$} & Yes & H4 \\
\hline OBE-PURI & 0.410 & 9.209 & 0.000 & {$[0.325,0.498]$} & Yes & H5 \\
\hline PURI-OI & 0.567 & 23.785 & 0.000 & {$[0.517,0.612]$} & Yes & H6 \\
\hline
\end{tabular}

\begin{tabular}{|l|l|}
\hline \multicolumn{2}{|c|}{ Legend } \\
\hline PI & Product Involvement \\
\hline FBI & Fashion Brand Involvement \\
\hline OBE & Online Brand Engagement \\
\hline OI & Purchase Intention \\
\hline PR & Other Involvement \\
\hline
\end{tabular}

Table 4: Summary of significance testing results for the proposed structural model

As seen above in Table 4, Hypothesis 1 predicts a positive relationship between product involvement and fashion brand involvement and was accepted at $\mathrm{p}=0.000$. Hypothesis 2 predicts a positive relationship between product involvement and purchase intention and was accepted at $\mathrm{p}=0.000$. Hypothesis 3 predicts a positive relationship between fashion brand involvement and online brand engagement and was accepted at $\mathrm{p}=0.000$, which further support the findings from Smith et al. (2016). Hypothesis 4 predicts a positive relationship between fashion brand involvement and purchase intention and was accepted at $\mathrm{p}=0.000$. Hypothesis 5 also predicts a positive relationship between online brand engagement and purchase intention and was accepted at $\mathrm{p}=0.000$, providing further verification for the findings from Smith et al. (2016). Finally, Hypothesis 6 predicts a positive relationship between purchase intention and 
altruistic involvement and was accepted at $\mathrm{p}=0.000$, confirming the findings proposed by $\mathrm{Hsu}$ and Lin (2008). The results from hypothesis 3, 4, and 5 support the results of Smith et al. (2016), whereas the results from Hypothesis 1, 2, and 6 extend the model. While all hypothesis proved to be significant, the positive relationship between Hypothesis 1,3,5, and 6 are the main objective of this study in analyzing a consumer's path to purchase and will be elaborated in further details in Section 6.3- Discussion of the Results.

After assessing the significance and relevance of the path coefficients in the structural model, the next step is to evaluate the $\mathrm{R}^{2}$ values- which define the amount of explained variance of endogenous latent (dependent) variables in the structural model (Hair Jr et al., 2016). These values help researchers judge the model's predictive power, known as in-sample predictive power (Rigdon, 2012; Sarstedt, Ringle, Henseler, \& Hair, 2014). The greater the $\mathrm{R}^{2}$ values, the greater the construct can be explained by the latent variables that point to it in the structural model via path relationships (Hair Jr et al., 2016). To help researchers, particularly those in marketing, better understand the predictive accuracy of the $\mathrm{R}^{2}$ values, Hair et al. (2017) proposed $\mathrm{R}^{2}$ can be classified into one of three categories: weak (0.25), moderate (0.50), and substantial (0.75). Based on these standards, the prediction of fashion brand involvement $\left(\mathrm{R}^{2}=0.31\right)$ and other involvement $\left(\mathrm{R}^{2}=0.32\right)$ were positioned between the weak to moderate level, and the prediction of online brand engagement $\left(R^{2}=0.59\right)$ and purchase intention $\left(R^{2}=0.60\right)$ were positioned above the moderate level. Greater $\mathrm{R}^{2}$ values signify that the values of the construct can be strongly predicted through the PLS path model, however fashion brand involvement and other involvement had values below moderate. These values may be due to a lack of previous research around the relationship between fashion brand involvement and other involvement in 
the purchasing of jeans in a social media setting. Therefore, it can be reasoned that the variance found in fashion brand involvement and other involvement is not only insightful but also critical to the extension of the proposed structural model as this variance requires further explanation. These results are further illustrated in Figure 3 below.

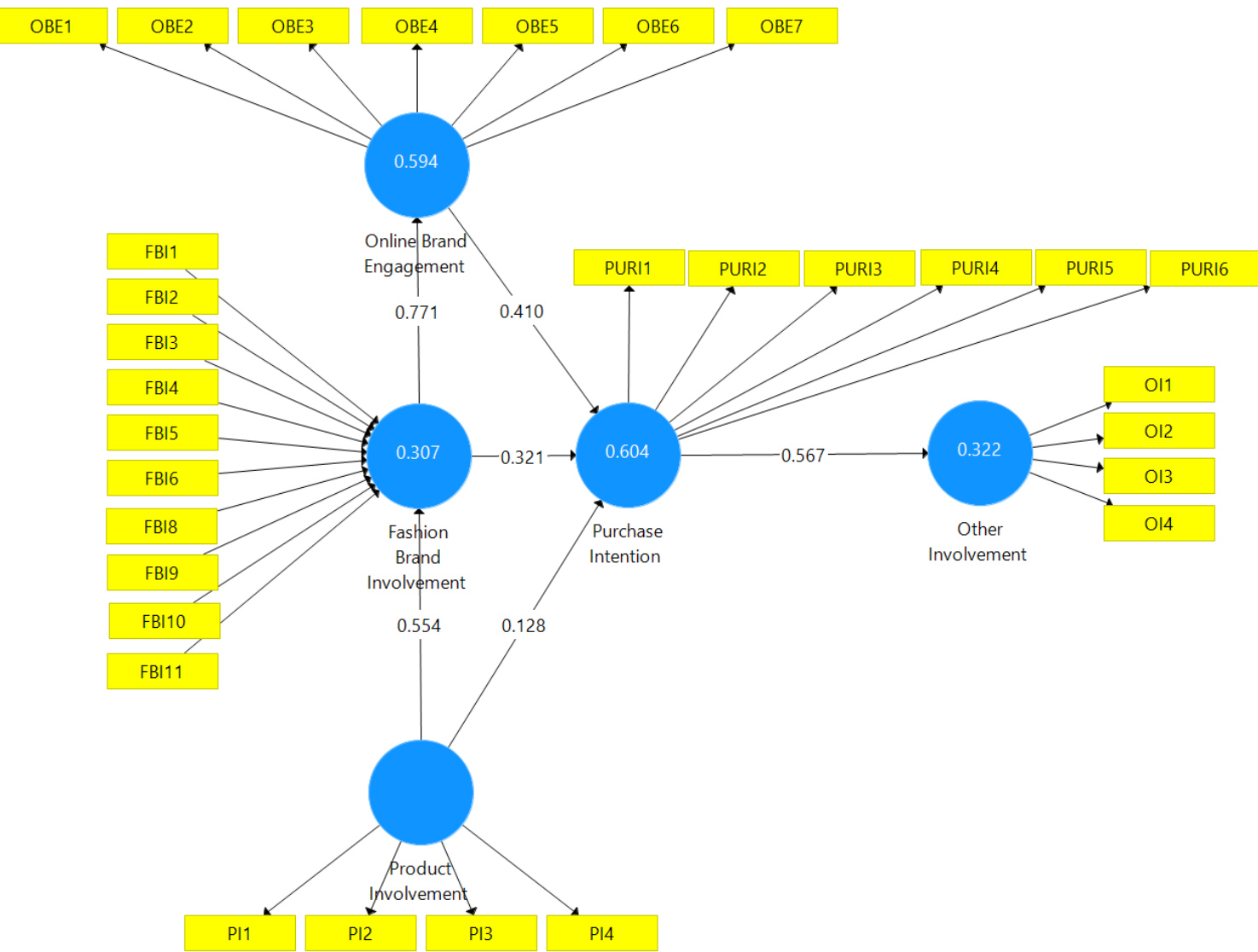

Figure 3: Model illustrating the results from the R2 and significance tests of the hypothesized paths to the constructs

An important observation to include from Figure 3 is that the model has two mediating relationships. Fashion brand involvement mediates product involvement and purchase intention and online brand engagement mediates fashion brand involvement and purchase intention. 
"Mediation occurs when a third variable, referred to as a mediator variable, intervenes between two other related constructs," (Hair Jr et al., 2016, p. 227). Thus, mediator variables govern the nature of the relationship between two constructs. By analyzing the strength of mediating relationships, cause-effect relationships between an exogenous construct and an endogenous construct can be revealed. When examining Figure 3, there is a direct effect from product involvement to purchase intention, and an indirect effect from product involvement to purchase intention through the mediating variable fashion brand involvement. There is also a direct effect from fashion brand involvement to purchase intention, and an indirect effect from fashion brand involvement to purchase intention through the mediating variable online brand engagement. According to Hair et al. (2017), when the indirect effect and the direct effect are both significant and point in the same direction, this can be recognized as complementary mediation. In Figure 3, the strength of the indirect effects is stronger than the strength of the direct effects. This means a stronger relationship lies to purchase intention through the mediating variables: fashion brand involvement and online brand engagement.

Following the assessment of the $\mathrm{R}^{2}$ levels, the assessment of the effect size $\left(\mathrm{f}^{2}\right)$ indicates the strength of an exogenous construct in explaining an endogenous construct, in terms of $R^{2}$. The effect size can also be classified into one of three categories: small (0.02), medium (0.15), and large (0.35) (Hair Jr et al., 2017). This research found large effects in the fashion brand involvement to online brand engagement (1.466) relationship, product involvement to fashion brand involvement (0.442) relationship, and purchase intention to other involvement $(0.474)$ relationship, as illustrated below in Figure 4. Relationships between the small to medium effect level were found in the fashion brand involvement to purchase intention (0.104) relationship and 
online brand engagement and purchase intention (0.144) relationship. And the product involvement to purchase intention (0.024) relationship was discovered to have a small effect. As seen in Figure 4, the model illustrates the relationships with a large effect in bold arrow paths. When examining a consumer's path to purchase jeans in a social media context, there seems to be medium to large effects shown for hypothesis $1,3,5$, and 6 . These results will be further elaborated in Section 6.3- Discussion of the Results.

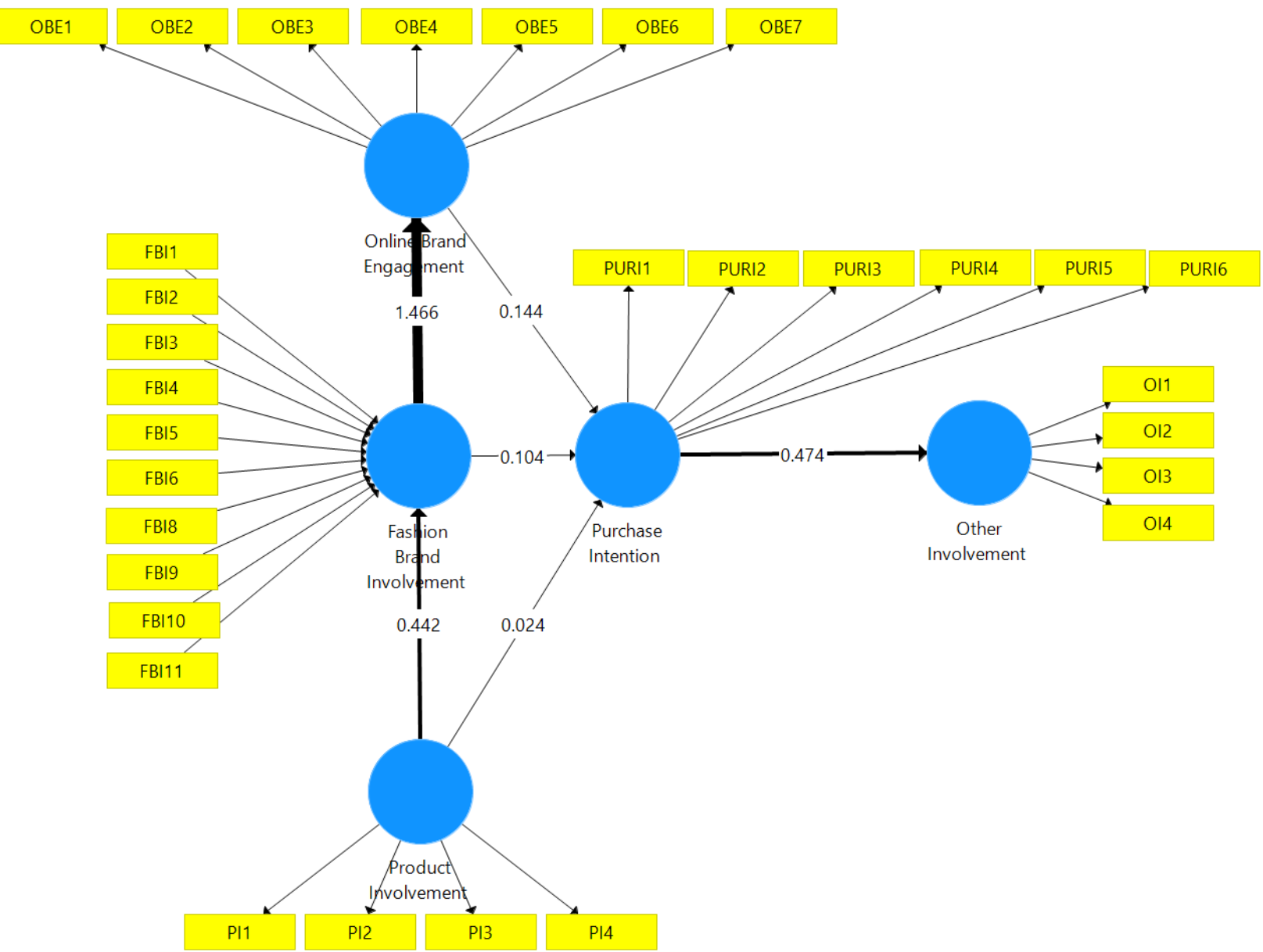

Figure 4: Model illustrating the results from the effect size (f2) 
After evaluating the in-sample predictive power $\left(\mathrm{R}^{2}\right)$ and effect size $\left(\mathrm{f}^{2}\right)$, researchers should also examine the out-of-sample predictive power represented by $\mathrm{Q}^{2}$ to estimate how accurate the model can predict data not used in the sample; exhibiting predictive relevance. According to Hair et al. (2017), a model's predictive relevance can be classified into three categories: small predictive power as 0.02 , medium predictive power as 0.15 , and large predictive power as 0.35 . These values can be acquired through a blindfolding procedure of the endogenous constructs in the model with a definite omission distance D (for this study an omission distance of $\mathrm{D}=7$ was applied). The omission distance $\mathrm{D}$ determines the number of blindfolding rounds. The aim of the blindfolding procedure is to include all observations for prediction, avoiding the removal of entire observations per blindfolding round. Therefore, the number of observations used in the original data set divided by the omission distance D must not yield an integer. Hair et al. (2017) recommends an omission between $20 \%(\mathrm{D}=5)$ and 10\% (D $=10$ ) of the data points per blindfolding round. As per Hair et al.'s (2017) recommendation, an omission of $15 \%$ was applied ( $\mathrm{D}=7$ ). As the original data set (799) divided by the omission distance $(\mathrm{D}=7)$ equals 114.14 , it is an appropriate omission distance to apply as it meets the criterion. The $\mathrm{Q}^{2}$ values seen in Appendix A12 for all four endogenous constructs are considerably above zero, indicating significance. More precisely, fashion brand involvement (0.170) and other involvement $(0.251)$ demonstrated predictive power above medium, whereas online brand engagement (0.396) and purchase intention (0.445) demonstrated large levels of predictive power. A summary of the predictive power test is illustrated in Figure 5 and the crossvalidated redundancy scores can be seen in Appendix A14. 


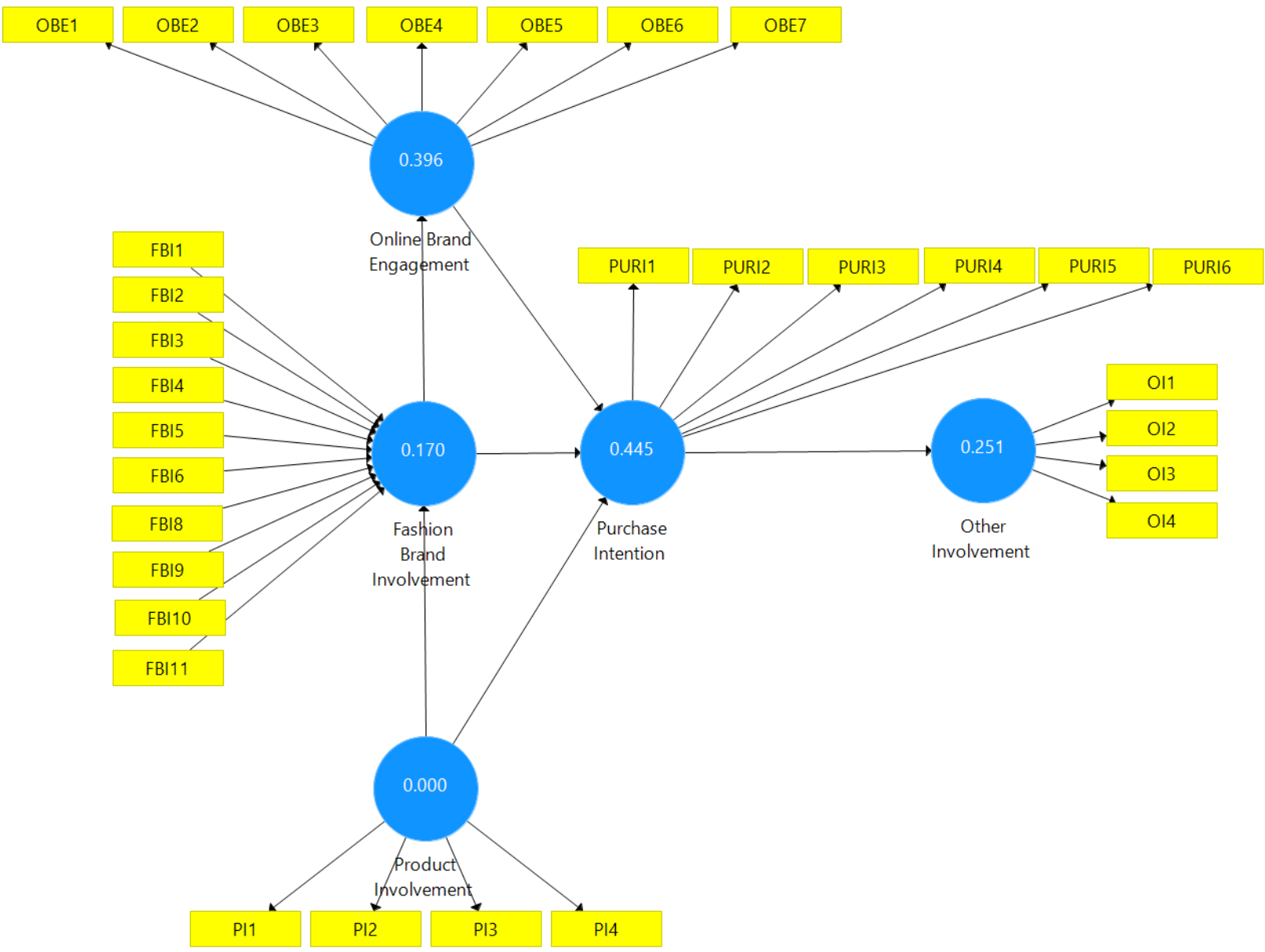

Figure 5: Summary of results for the predictive power tests (Q2) 


\section{Summary \& Discussion}

The goal of this study was to develop and test a model to explore the influence of product involvement, fashion brand involvement, other involvement, online brand engagement, and purchase intention on a consumer's path to purchase jeans in a social media context. Through a quantitative research methodology followed by a deductive approach, the proposed model tested six hypotheses in the Canadian retail landscape of a universal fashion item, jeans. In this chapter, an interpretation of the key findings and contributions to theory and practice must be examined. Furthermore, the limitations of this study and directions for future research will also be highlighted.

\subsection{Summary of Findings}

In the proposed structural model, a total of 6 hypotheses were tested. As mentioned before, three hypotheses were tested in a previous study conducted by Smith et al. (2016) that examined purchase intention, fashion brand involvement and online brand engagement. Nonetheless, three other hypotheses remain that prove to be novel and shed a new light on a consumer's path to purchase. A summary of the hypothesis tests is listed below, followed by an interpretation of the outcomes.

- H1 (there is a positive relationship between product involvement and fashion brand involvement in a social media context) - this hypothesis was accepted with a significant result of $(\mathrm{p}=0.000)$; 
- $\mathrm{H} 2$ (there is a positive relationship between product involvement and purchase intention in a social media context) - this hypothesis was accepted, with a significant result $(\mathrm{p}=0.000)$;

- H3 (there is a positive relationship between fashion brand involvement and online brand engagement in a social media context) - this hypothesis was accepted, with a significant result $(\mathrm{p}=0.000)$, aligned with previous research concluded by Smith et al. (2016);

- H4 (there is a positive relationship between fashion brand involvement and purchase intention in a social media context) - this hypothesis was accepted, with a significant result $(\mathrm{p}=0.001)$, aligned with previous research concluded by Smith et al. (2016);

- H5 (there is a positive relationship between online brand engagement and purchase intention in a social media context) - this hypothesis was accepted with a significant result of $(\mathrm{p}=0.001)$, aligned with previous research concluded by Smith et al. (2016);

- H6 (there is a positive relationship between purchase intention and altruistic involvement in a social media context $)$ - this hypothesis was accepted with a significant result of $(\mathrm{p}=0.000)$;

The next section interprets the findings of each hypothesis and why they were accepted. This discussion aims to reflect the objective of our study.

\subsection{Interpretation of the Findings}

The first hypothesis, which proposed a positive relationship between product involvement and fashion brand involvement, was accepted. This hypothesis was justified based 
on a study of jeans where product involvement was demonstrated to be a significant antecedent of brand decision involvement (Mittal \& Lee, 1989). To support the application of this study in a fashion context, product involvement found in fashion clothing was discovered to influence consumer attitudes of fashion brands (O'Cass \& Choy, 2008), demonstrating a relationship between product involvement and fashion brand involvement. According to Kohli and Thakor (1997), brand names provide a source of differentiation for consumers. In today's competitive and saturated market, it has become increasingly difficult to differentiate products purely on physical attributes (Kohli \& Thakor, 1997). Considering a product such as jeans, intrinsic cues such as fabric and style are hard to judge when there are many alternatives at hand. As a result, consumers begin to express brand involvement and preferences towards certain brands to narrow down their purchase from a broad product item to a specific brand name. This transition is evident in many real worlds examples, such as Kohli and Thakor's (1997, p. 207) research that pointed out "we do not buy jeans; we buy Levi's. We do not buy sunglasses; we buy Ray Ban. And, we do not buy sparkling water; we buy Perrier”. Additionally, O’Cass and Frost's (2002) study on the types of products we use and how we communicate this to others around us through brands also suggests a relationship does exist between product involvement and brand involvement. Specifically in fast-fashion, a recent study found by proactively involving customers with products can create an emotional connection to a brand and further solidify a brand's relationship with the customer (Kim, Park, \& Glovinsky, 2018). The $\mathrm{f}^{2}$ values also showed large effects from product involvement to fashion brand involvement (0.442), in line with Kohli and Thakor's (1997) findings. 
The next hypothesis examined was hypothesis 2 which proposed a positive relationship between product involvement and purchase intention, was accepted. Although the data has confirmed the influence of product involvement on fashion brand involvement, the data also confirms product involvement can directly impact purchase intention as well. As seen in Section 5.3 Assessment of the Structural Model, Figure 4 illustrates the results from the effect size $\left(\mathrm{f}^{2}\right)$ tests, which shows the path from online brand engagement to purchase (0.144) is significantly stronger than the path from product involvement to purchase intention (0.024). While a stronger impact exists between online brand engagement and purchase intention, the influence of product involvement on purchase intention cannot be ignored. Since almost all organizations aim to sell their products or services to achieve sales, it is important to recognize other forms of influence on purchase intention. Product involvement has been historically known as one of the most significant variables in consumer research (Martin, 1998) as well as a predictor of purchase intent (Evrard \& Aurier, 1996), and reflects a consumer's personal relevance with a product. This sense of personal relevance commonly known as self-concept, refers to the perceptions and attitudes people have of themselves as objects (Solomon, 1996, p. 226). Self-concept is important for marketers to grasp because people consume products and brands that relate to their self-image. Fashion in particular, symbolizes a key consumption product category for consumers, as some will spend more on clothing that says something important about them regardless of their level of disposable income (Goldsmith, Moore, \& Beaudoin, 1999). However, unlike products, brands are known for its ability to portray personalities or images; and consumers desire brands that match their self-concept or the image they aspire to project to others (Schiffman \& Kanuk, 1997, p. 136). Hence, the direct path from product involvement to 
purchase intention (0.024) appears to be weaker compared to the direct path from fashion brand involvement to purchase intention (0.104).

The third hypothesis examined was hypothesis 3 , which proposed a positive relationship between fashion brand involvement and online brand engagement and was accepted. Traditionally, when researchers examine involvement in marketing studies, an overlap with engagement is commonly found (Calder et al., 2009). Historically, some scholars have claimed engagement leads to involvement. For instance, the driving motive behind a consumer processing and engaging with an advertisement is their search for relevant information (Burnkrant \& Sawyer, 1983). Thus, engagement driven by information search/product knowledge may be an antecedent of involvement because engagement may influence the level of involvement that a consumer feels towards a product/brand/promotion (Ephron, 2006; Harvey, 1997). However, other scholars have argued that it is in fact involvement which precedes engagement (Hollebeek et al., 2014; D. Smith et al., 2016). According to the data in this research, it was confirmed that involvement does precede online brand engagement. Specifically in a fashion context, studies have found that consumers who are passionate about a fashion brand express high levels of involvement in fashion brands and thus inherently desire to further engage in and form deeper bonds with these fashion brands (Fournier, 1998; J. O. Park et al., 2011). Marketing studies have also shown the positive influence fashion brand involvement has on engagement as it has been proven to impact consumers' intention to adopt the latest styles and clothing (Rahman et al., 2014). Furthermore, researchers have noted high levels of online participation such as a high frequency of posts, likes, and comments from consumers were indicative of high levels of engagement (Gummerus, Liljander, Weman, \& Pihlström, 2012). 
These forms of online engagement have been viewed as a consequence caused by brand involvement. For instance, Hur, Ahn, and Kim (2011) found brand commitment to be a predictor of members' behaviours in an online community, such as participating in community activities. This may explain why consumers who are attached to a particular fashion brand and express high levels of fashion brand involvement may like, comment, share, and follow the brand's platform on social media; indicating high levels of online brand engagement.

The fourth hypothesis, which proposed a positive relationship between fashion brand involvement and purchase intention, was accepted. While the data has already confirmed a relationship exists between fashion brand involvement and online brand engagement, a relationship between fashion brand involvement and purchase intention has also been confirmed. Referring back to Section 5.3 Assessment of the Structural Model, Figure 4 illustrates the results from the effect size $\left(\mathrm{f}^{2}\right)$ tests, which shows the path from online brand engagement to purchase intention (0.144) is stronger than the path from fashion brand involvement to purchase intention (0.104). While a stronger impact exists between online brand engagement and purchase intention, the influence of fashion brand involvement on purchase intention cannot be overlooked. Previous studies have noted consumers buy products and brands that match or enhance their actual or ideal self-concepts (Malhotra, 1988; Onkvisit \& Shaw, 1987; Sirgy, 1982). Hence, fashion brand involvement is an especially important concept to study in the context of fashion behavior because of the importance brands have in conveying self-concepts. However, in comparison to the phenomenon of involvement, in this study online brand engagement has demonstrated a greater influence on purchase intention. Particularly in an online setting, the interactive nature of digital and social media has advanced retailers' ability to 
exchange information with consumers as well as engage with one another (Sashi, 2012). These interactions have transformed the traditional way businesses sell and consumers buy. For instance, through online platforms and social networks consumers have become active cocreators of consumption and personal experiences (Furat \& Dholakia, 2006). This is evident amongst many consumers who may even turn into ambassadors for the brand and produce content on their personal online platforms which influence the purchase decisions of others in peer-to-peer interactions. An example of such fashion retailer who has successfully transformed the way retailers advertise and engage consumers is Revolve, an online multi-brand store founded in Los Angeles for the millennial women who desires online access to the latest designer trends. Since its introduction in 2003, the company reported \$1 billion in sales in 2017 (Cheng, 2018). China is their second biggest market with a social revenue share 10 times higher than the United States, as Chinese consumers are more engaged than ever using social media to post promotional pictures and communicate to their friends that Revolve is a website they can trust (Rapp, 2016). In regard to Revolve's immense popularity in China's fashion e-commerce market, Revolve co-founder and co-CEO Michael Mente stated, "The consumer came to us before we invested [in China], and they were really engaged" (Rapp, 2016, p. 3). Thus, supporting the strength of online brand engagement to purchase intention is greater than fashion brand involvement to purchase intention.

The fifth hypothesis examined was hypothesis 5 which proposed a positive relationship between online brand engagement and purchase intention, was accepted. Research has demonstrated that informational and interactive websites can enhance consumers' attitudes 
towards online shopping and their purchase experience (Fiore \& Jin, 2003; J. Kim \& Forsythe, 2009). In the context of brand engagement, it has been shown that a strong attachment to a brand saves a customer the cost of seeking new relations with other brands (Chaudhuri \& Holbrook, 2001). Additionally, the level of attachment and engagement with a brand can strongly predict how often the brand was purchased in the past and will be purchased in the future (McAlexander, Kim, \& Roberts, 2003; Thomson, MacInnis, \& Park, 2005). This may explain why consumers who are already engaged with a brand are more likely to purchase from it compared to consumers that do not express brand engagement, as they have already formed a brand relationship that increases brand engagement, which is a key antecedent of current and future purchases. The influence of brand engagement in predicting purchase intent can be seen in Esch's et al. (2006) study which found that to stimulate future purchase intention, a brand must build a positive brand relationship with the consumer. Additionally, brand engagement applied to an online setting can further heighten purchase intention as seen in the acceptance of this hypothesis. As consumers increasingly search for product information and brand promotions, online user reviews have become a vital source of information for consumers; substituting and complementing other forms of business-to-consumer (B2C) and offline WOM marketing (Chevalier \& Mayzlin, 2006). Therefore, the more engaged consumers are about certain brand promotions and product reviews seen online, the more likely a consumer is to be willing to purchase.

Finally, the last hypothesis examined was hypothesis 6 which proposed a positive relationship between purchase intention and other involvement, was accepted. In consumer behaviour studies, altruism has popularly investigated ethical businesses that advocate social 
responsibility as altruistic involvement is the motivation to help others in need (Hustvedt \& Dickson, 2009). The earliest study intersecting altruism and fashion was by Dickson and Littrell (1977) who measured altruistic attitudes in relation to clothing purchases from an alternative trading organization. However, this study aims to show consumers can be interested in the beneficial outcomes of their purchase beyond the phenomena of social responsibility. Although altruism has intersected fashion in previous studies, in this study, altruistic involvement was investigated in a new perspective to bring light to the science behind referrals. Studies have shown consumers seek opinions for information that will reduce the risk in their purchase decisions and improve their status within social networks (Flynn, Goldsmith, \& Eastman, 1996). Furthermore, consumers also seek opinions to maximize the product benefits received versus cost and to gather advice from peers to reduce potential risks (Goldsmith \& Horowitz, 2006). Therefore, when a referral of a product or service is driven by altruistic involvement, it means a consumer is sharing their thoughts and reviews to help others make informed purchase decisions. The data in this research confirmed there was a connection between purchase intent and altruistic involvement, demonstrating the purchase experience has a strong impact on a consumer's willingness to help others, ultimately motivating consumers to share positive or negative experiences to protect and guide other consumers in making better purchase decisions. When referring a product or service to one's social network, referrers weigh expected intrinsic and extrinsic benefits received through sharing (Hayes, King, \& Ramirez Jr, 2016). Kankanhalli, Tan, and Wei (2005) found that intrinsic benefits such as the enjoyment of helping others, and extrinsic benefits such as the reciprocity people expect to gain by sharing, influences a consumer's willingness to refer. Therefore, the stronger a consumer feels the need to help others, the greater chances of a product or brand being referred. To support the findings from this study, 
Hsu and Lin (2008) examined knowledge-sharing within blogs and identified four knowledge sharing motivations that validate the impact of altruism on sharing: expected reciprocal benefits, reputation, trust, and expected relationships. In Hayes' et al. (2016) study of viral advertisements, altruism was also found to positively and directly influence the likelihood of referring an ad within Facebook networks. From both studies altruistic involvement can be understood as a key determinant of sharing behavior (Hayes et al., 2016), and as demonstrated in the findings, purchase intention impacts the motivation behind referring goods and services to one's social network.

\subsection{Theoretical Implications}

Based on findings from previous research, this thesis aimed to understand a modern consumer's path to purchase jeans in a social media context by examining constructs relevant to today's fashion consumption, such as product involvement, fashion brand involvement, other involvement, online brand engagement, and purchase intention. This study proposed to contribute knowledge around consumer behaviour, fashion, and social media consumption, opening doors to further understand new paths to purchase. This study filled a research gap by applying a previously studied phenomena such as product involvement, fashion brand involvement, altruistic involvement, and online brand engagement to newer contexts such as online and social media settings, to produce new theoretical contributions of knowledge to the body of consumer behaviour and fashion studies. The consumers in this study demonstrated product involvement does have a positive influence on fashion brand involvement, validating the work of Mittal and Lee's (1989) study on jeans which highlighted product involvement as an 
antecedent of brand involvement. Online consumer socialization has been revealed to affect purchasing decisions in two key ways: directly through conforming to social standards endorsed by peers, and indirectly by reinforcing product involvement (Wang, Yu, \& Wei, 2012). Since social media features peers who act as socialization agents and offer product information and evaluations quickly, social media is a medium that can facilitate product involvement and information (Gershoff \& Johar, 2006; Taylor, Lewin, \& Strutton, 2011). Therefore, consumers who express high levels of product involvement can quickly form high levels of brand involvement as well, as peer communication expressed through social media facilitates learning about peers' consumption experiences, such as brand preferences. Furthermore, peers' ownership of a particular product can motivate a consumer to model their peers and purchase the same brand as their peers (Lueg \& Finney, 2007). Hence, a positive relationship exists between product involvement and brand involvement in a social media context.

Another key finding from the study proposed that the structural model has two mediating relationships. Fashion brand involvement mediates product involvement and purchase intention, and online brand engagement mediates fashion brand involvement and purchase intention. Theoretically, mediators can provide an explanation behind the relationship between an exogenous and endogenous construct through intervening these relationships. By gaining information from an exogenous construct and converting it into an endogenous construct, the mediator can uncover the true relationship between an independent and dependent construct (Hair Jr et al., 2016). In this research, when examining the influence of product involvement on purchase intention, fashion brand involvement intervenes in the relationship between the two constructs. According to theory, a relationship between product involvement and purchase 
intention has already been verified but there is little explanation around how consumers translate their product involvement into purchase intention. Consumers that are perceived to express high product involvement levels may not express high purchase intention. In other cases, consumers who express lower levels of product involvement may highly intend to purchase. These contrasting observations pose a question whether there is another factor behind the transition of product involvement to purchase intention. According to the findings, in this proposed model the intervening variable was discovered to be fashion brand involvement. This means if a consumer is perceived to express high levels of product involvement, then this observation may lead to higher fashion brand involvement levels, and ultimately to increased purchase intention. In this case, the relationship between product involvement and purchase intention is a direct effect, and the relationship between product involvement, fashion brand involvement, and purchase intention is an indirect effect. According to the findings, the strength of the indirect mediating effects was found to be stronger than the strength of the direct effects; meaning a stronger relationship exists to purchase intention through fashion brand involvement. The influence of this mediation supports the interpretation of the findings which proposed consumers express preferences towards certain brands to narrow down their purchase decision from a broad product category to a specific brand name. This may be by caused by virtue of brands which serve as a source of product differentiation (Hunt, 2019). Especially when there are many alternative items at hand and a reluctance to try new products, fashion brand involvement's mediation in between product involvement and purchase intention can strengthen a consumer's willingness to purchase jeans. 
When further examining the influence of fashion brand involvement on purchase intention, online brand engagement was found to intervene in the relationship between these two constructs. This means if a consumer is perceived to express high levels of fashion brand involvement, then this observation may lead to higher online brand engagement levels, and ultimately to increased purchase intention. By examining both mediators, a more comprehensive picture of the theoretical implications through which an exogenous construct influences an endogenous construct can be found. In this case, the relationship between fashion brand involvement and purchase intention is a direct effect, and the relationship between fashion brand involvement, online brand engagement, and purchase intention is an indirect effect. According to the findings, the strength of the indirect mediating effects was found to be stronger than the strength of the direct effects; meaning a stronger relationship exists to purchase intention through online brand engagement. The influence of this mediation supports the interpretation of the findings which proposed consumers who engage with a brand are more likely to purchase from it compared to consumers that do not express brand engagement, as they have developed a brand relationship that increases a consumer's willingness to purchase, often prevalent in online settings (Esch, Langner, Schmitt, \& Geus, 2006). Overall, fashion brand involvement and online brand engagement are important theoretical implications because they strengthen a consumer's purchase intention through indirect mediation, thus play an important role in a consumer's path to purchase jeans in a social media context.

Another key finding from the study highlighted that fashion brand involvement and other involvement had low $\mathrm{R}^{2}$ values. Theoretically, $\mathrm{R}^{2}$ values indicate the variance of the endogenous constructs in the proposed structural model (Hair Jr et al., 2016). Generally, the higher the $\mathrm{R}^{2}$ 
values, the greater the predictive power to explain key constructs in the structural model. However, low values of $\mathrm{R}^{2}$ does not mean the construct is not useful (Ash \& Shwartz, 1999). Although $\mathrm{R}^{2}$ values can draw important conclusions about the model, these values alone cannot determine whether the proposed model has adequate significance. In research fields such as consumer behaviour and psychology, low $\mathrm{R}^{2}$ values are expected as predicting human behaviour is more complex than predicting material mechanisms (Colton \& Bower, 2002). Furthermore, a low $\mathrm{R}^{2}$ value poses a challenge when making precise predictions through a small sample size (Ash \& Shwartz, 1999), which is not the case in this study. $\mathrm{R}^{2}$ values can estimate the strength of the relationship between the structural model and the endogenous constructs, however it is not a hypothesis test for this relationship. When $\mathrm{R}^{2}$ values are evaluated alongside other statistics, a better understanding of the structural model's significance can be formed. In this research, these low $\mathrm{R}^{2}$ values may be caused by the limited research around the relationship between fashion brand involvement and other involvement in the purchasing of jeans in a social media setting. Hence, this discrepancy found in fashion brand involvement and other involvement is essential as it supports the extension of the proposed structural model.

\subsection{Implications for Practice}

In practice, this work provides practitioners in the field a modern day understanding of the key influences a consumer faces during their path to purchase a fashion product in a social media context. This research also assists marketers and advertisers better understand how to effectively influence a consumer's willingness to purchase on social media and gain the most

from their marketing strategies. As today's consumers frequently change their preferences at the 
speed they scroll through their social media feeds, traditional mediums such as malls and department stores are losing the relevance they once held to the consumer. "Malls have evolved with society and they need to continue evolving otherwise they will wind up abandoned and 'dead'," (Watson, 2016, p. 8). Thus, a modern understanding of the elements in a consumer's path to purchase in a more relevant context such as social media, can assist practitioners in understanding and meeting the expectations of today's consumers. Hudson Yards, a mall of the future located in New York City has been described as 'a 'new-age mall' where shoppers who have been seeing some of these up-and-coming retailers on their Instagram feeds can test products before buying them" (Thomas, 2019). This shows the importance of online brands in generating large volumes of traffic on social media- that physical department stores want to invest and capitalize on this growth opportunity. As many massive retailers such as the Gap, Payless, and Victoria's Secret close down their store operations this year, online brands such as Casper, the mattress maker, will open at least 850 stores altogether by 2023 demonstrating the power of digitally-minded brands (Thomas, 2019). Hence, this research helps equip practitioners with a digital awareness and understanding of how product involvement, fashion brand involvement, altruistic involvement, and online brand engagement can impact purchase intention through the power of social media.

This research also found large effects in the product involvement to fashion brand involvement (0.442) relationship and fashion brand involvement to online brand engagement (1.466) relationship, as well as a close medium-sized effect on fashion brand involvement to purchase intention (0.104). These effect sizes help identify the key influences a consumer undergoes on their path to purchase jeans in a social media context and therefore, practitioners 
should focus on the relationship from product involvement to fashion brand involvement and fashion brand involvement to online brand engagement to encourage purchase intention. When consumers express joy about a product and display their level of interest in purchasing a product, they begin to invest effort in searching for the right brand to purchase the product they desire. Practitioners should thus utilize social media to create posts and messages that influences consumers to identify with their brand and build fashion brand involvement. In line with the findings, consumers who express fashion brand involvement and become strongly engaged online with the brand are more willing to purchase. Hence, practitioners should seek to create more opportunities through social media for consumers to affiliate with their brand, talk to peers about their brand, follow news regarding the brand, receive exclusive promotions and other engaging communication such a social media-based giveaways and contests from their brand. Overall, the findings suggest it is important for practitioners to regard social media as a valuable tool as it provides a relevant platform for businesses to solidify relationships with consumers, leverage intimate interactions with consumers, and increase involvement with consumers (Wang et al., 2012). In a saturated market dominated by fast-fashion and consumers' scepticism towards brands and traditional marketing (Tuškej, Golob, \& Podnar, 2013), social media is an important tool to reduce uncertainty between the consumer and the brand. Practitioners who harness the power of social media can augment connections with consumers on an emotional level and portray an alignment between their brand identity and the consumer's identity. When this happens, studies show consumers that perceive similarities between their self-concept, brand values, or other influential peers endorsing the brand, can lead to more involved consumers (Coelho, Rita, \& Santos, 2018). In the past, interacting with consumers posed a challenge for brands due to a lack of innovative technology, however today brands can converse with 
consumers on a personal basis and consumers are becoming overwhelmed with the multitude of messages (Gensler, Völckner, Liu-Thompkins, \& Wiertz, 2013). Therefore, practitioners should emphasize strategies that grab consumers' interest and involvement (Enginkaya \& Y1lmaz, 2014). As seen in the findings, practitioners that induce product and fashion brand involvement are the ones that deliver results.

Additionally, the findings also show that online brand engagement is influential in triggering purchase intention with a close to medium effect size between online brand engagement and purchase intention (0.144). Supporting studies also demonstrate that generating brand involvement amongst consumers with high fashion involvement can increase online brandrelated communications (Wolny \& Mueller, 2013). Therefore, practitioners should place an emphasis on online advertising and increased interactivity when operating social media websites to increase online engagement. Increased interactivity may also encourage consumers to share product information through social media, spread reviews about the advertised brand, and build new kinds of relationships with the brand (Wang et al., 2012). An advertiser that can utilize social media to respond effectively to consumer reviews possesses a great advantage because they can engage customers in online conversations, recognize their needs, and maintain brand relationships during and after the purchase process; improving online brand engagement (Bronner \& de Hoog, 2010). Maurer and Wiegmann (2011) recommend practitioners should also emphasize on 'friendvertising' over advertising to form solid relationships with consumers and gain their loyalty instead of using social media for commercial purposes. Hence, practitioners should plan on building more effective online brand engagement strategies that reflect the importance of this motivation. 
Finally, in alignment with the findings of this research that found large effects in the other involvement to purchase intention (0.474) relationship, practitioners should also understand the value of consumers who express high altruistic involvement and take advantage of their ability to influence referrals. The results of this finding can help fashion brands better understand how to influence eWOM communication through altruistic motivations found in consumers on social media and avoid less effective commercial-based strategies. Given that online ads, sponsored marketing, and any advertising from a commercial standpoint may be viewed as inauthentic, practitioners should start to actively monitor organic opinions expressed by consumers on social media around their brand. Many forms of organic and authentic consumer feedback can be found through online product ratings, reviews, blogs, discussion forums, and sharing of comments or images. Practitioners should focus specifically on the credibility of altruism in peer communication and the consumers' ability to influence the brand's image through altruistic-motivated eWOM, as these online comments may lead to potential referrals and sales. Fashion in particular, has seen an increase of bloggers and opinion leaders producing trends and influencing how a fashion brand is perceived in the market, inherently becoming an industry dominated by peer influence rather than traditional fashion magazines or designers (Wolny \& Mueller, 2013). Therefore, it is important for practitioners to utilize the insight gained from the opinions expressed by consumers in order to serve their customers' needs and wants better, leading to positive eWOM. In addition to studies highlighting altruistic involvement as a key sharing behaviour on social media (Ho \& Dempsey, 2010), practitioners should focus on developing marketing strategies such as the ones listed above that reflect the importance of altruistic involvement. 


\subsection{Limitations}

It is important to understand what this research does not intend to or cannot accomplish; hence this section will call attention to the boundaries within which this research was conducted. Limitations are parameters placed around the research methodology, and often concern the nature and size of the sample, the uniqueness of the setting, and the time period in which the study was conducted (Joyner, Rouse, \& Glatthorn, 2018, p. 208). These limitations can potentially impact the application of the research methodology and the interpretation of the findings, thus need to be noted and further discussed.

A key limitation defined in this study involves the time period this research was conducted in. In this research, data was outsourced from a database that was used in a previous study conducted by Smith et al. (2016). This data was collected from participants at a single point in time, thus it did not reflect the participants' behaviour in real time. Data collected real time such as during a promotional campaign may result in different findings. Also, the data does not capture which specific advertisements, images, or communication are effective or relevant to the consumer as it was out of the research scope outlined in this study. Another important limitation attention should be brought to is that other forms of marketing and communication, such as direct mail or direct selling, was not investigated in this study. This study primarily focused on the impact of social media on online purchase intention. This includes consumers who may have used social media to make a purchase in-store or an information search in-store 
which may have led to purchase online. Finally, a study that examines consumers' purchase behaviour, other involvement, and social media would have greatly benefitted from continuing to follow-up and track consumer behaviour after the survey was conducted. However, the use of surveys presented a limitation that prevented contacting the participants of this research after the survey was completed; as an agreement was previously established with participants to protect their anonymity. Additionally, using a quantitative method like PLS-SEM means that research questions can be confirmed or rejected and the proposed model could be further statistically analyzed (Hair Jr et al., 2017), fulfilling the scope of this research. However, to examine other antecedents to purchase outside the parameters of this study, such as an individual's awareness, consideration, preferences, purchasing, experience, and loyalty, a deeper qualitative investigation is needed such as interviews with consumers to reveal other underlying factors and antecedents that may lead to purchase influence. Additionally, this data would have to be collected over a long period of time to engender data that has captured cyclical behavioural patterns.

\subsection{Recommendations for Future Research}

Opportunities exist for future research from both a theoretical and methodological standpoint. For instance, a key phenomenon that is important to social media marketing research that was not explored in this study is lurkers. Lurkers can be defined as passive members that dominate online communities in terms of membership (Nonnecke \& Preece, 2000). These silent members that make up the majority of online communities often view content but refrain from contributing, displaying the act of "lurking". In many studies, this passivity exhibited through

lurking has been commonly linked to TV viewers (Morris \& Ogan, 1996), who simply observe 
content displayed. The term 'lurker' used to describe these individuals generally connotes a lowvalue, marginal role that is characterized by reluctance and lack of readiness to contribute to the community (Cranefield, Yoong, \& Huff, 2015). These virtual members are most commonly viewed as inactive or invisible participants (Sun, Rau, \& Ma, 2014). Studies show these lurkers may make up approximately $90 \%$ of an online community (Preece, 2001). Therefore, as the success of online brand communities is linked to the volume of members' contributions (Iriberri \& Leroy, 2009), lurking proves to be a phenomenon largely profitable for corporations if understood better. Hence, future research can aim to understand the hidden value of lurkers in terms of the vital role lurking behaviour plays in impacting shopping behaviour. As lurkers account for a majority of members within any given online community, it is important to understand the underlying lurking characteristics that influence the shopping behaviours of the vast majority of consumers. While previous research shows that most of the studies centred around lurkers are focused on understanding their motives behind lurking, there is limited research that captures lurkers' impact on purchase consumption. With the widespread adoption of e-commerce, it is imperative for businesses to understand the value represented from triggering purchase behaviour out of the largest demographic that inhabit online communities.

From a methodological perspective, as this study requires participant observation to understand the curiosity-based characteristics of lurkers, the data collection research strategy most appropriate for this study is the use of questionnaires. Prior studies focused on lurking conducted by Takahashi et al. (2003) and Arnold and Paulus (2010) advise that researching lurking in a community setting is not the best method to understand the value of these members as the lurker's activities are either invisible or absent, presenting challenges when recording this 
behaviour in natural social settings. Therefore, conducting questionnaires in a semi-natural setting is the best method to track further and observe the phenomenon. From the data used in this study, out of the 799 respondents, 300 respondents were identified as lurkers and can be further examined in future research. This data proves to be an optimal sample size as it allows for the examination of lurkers in a ratio of approximately 1:3 and can be utilized to report on their participation levels and shopping behaviour in online communities and social media. As the questionnaire responses will be recorded in pre-coded categories, some levels of measurement and key constructs can include: shopping habits, social media and brand community involvement/engagement, posting frequency, purchase intention, lurking identification, information-seeking and eWOM. The data analysis method should also take a quantitative approach; utilizing SmartPLS to conduct the partial leased structural square equation modeling (PLS-SEM) method. This prediction-oriented approach is the most appropriate data reduction and data analysis method for this study as it can be utilized to investigate the relationships between constructs such as curiosity, information-seeking behaviour, and lurking, which have never been studied together before (Hair, Ringle, \& Sarstedt, 2011; Hair Jr, Hult, Ringle, \& Sarstedt, 2016). Through the PLS-SEM method, a more complex model for purchase intent can be further developed and tested on both lurkers and non-lurkers to investigate if any significant differences exist in the shopping behaviour of both demographics.

By examining additional offline and online influences in the context of fashion-related purchases through social media can add further value to this research. Additional variables that can supplement the proposed model and further enhance this study include influences such as: self-involvement, social interaction, advice seeking, and eWOM engagement. Self-involvement 
occurs when a product acts as a means through which a consumer can satisfy certain emotional needs (Dichter, 1966). Social interaction can be seen as the need to receive social benefits by commenting and posting in a virtual community (Hennig-Thurau et al., 2004). Advice seeking can be described as a genuine interest in other consumers' opinion and advice (Hennig-Thurau et al., 2004) And eWOM engagement describes consumers' online engagement in eWOM communication (Wolny \& Mueller, 2013). The scales for these variables were adapted from Wolny and Mueller (2013) and were also incorporated in the questionnaire developed for this study, hence these variables are valid additions that can further extend the model for future research.

\subsection{Conclusion}

This study proposes that product involvement, fashion brand involvement, other involvement, and online brand engagement influence purchase intention amongst consumers in a social media context. These key constructs are the focus of our study and their measurement scales have been adopted from Wolny and Mueller (2013). Findings from this study will guide corporations to make smarter decisions and effective investments into their marketing strategy. This study also contributes to the body of knowledge by demonstrating that for today's consumer, the willingness to purchase does not solely depend on an approach offering trendy products or high-end brands. Rather, findings have shown a path to purchase seems to exist, which in the proposed model begins at product involvement, leading to fashion brand involvement, then online brand engagement before leading to purchase intention, followed by other involvement post-purchase. This process assumes that consumers initially become involved 
with a certain product such as designer jeans, then filter their search by narrowing down the fashion brands they are passionate about, such as Levis. As the consumer gets closer to the fashion brands they like, they begin to express online brand engagement which can include activities such as following the brand's social media platforms to say up to date on their latest designer jean collections and sales promotions. Once a consumer has become engaged with a fashion brand, they have developed a relationship with the brand, thus are most likely willing to purchase from them. After the purchase depending on the positive/negative experience received from shopping in-store or online, a consumer is more likely to express altruistic involvement where they will refer the product or brand to their friends and family or advise their social circle to avoid it.

This study used PLS-SEM to examine six hypotheses which were confirmed, including three new hypotheses from the six. While the model had moderate to substantial predictability for purchase intention, the effect size $\left(\mathrm{f}^{2}\right)$ tests from the assessment of the structural model were analyzed to assess the strength of each path and gain insights into the strength of the consumer journey. The results from the PLS-SEM techniques provides a richer, statistical analysis beneficial to advertisers and marketers as they will develop a deeper understanding regarding the key forms of influences a consumer may face during their path to purchase thus, can plan more effective marketing strategies that maximize the most purchase intent from a consumer. This research contributes to the current fashion and marketing literature by applying traditional theories to a new and relevant context to better understand modern patterns of consumer behaviour. Specifically, this research advances the findings around the influence of product involvement, fashion brand involvement, altruistic involvement, and online brand engagement 
on purchase intention in social media, which is continually evolving and transforming businesses today. Given the limitations of this study, it is important to recognize that the findings are meant to reflect a step forward towards a better understanding of a new and relevant application of involvement and engagement influences found in the consumer's modern purchase journey. 


\section{Appendices}

\section{A1: Key Findings from Seminal Articles on The Inception of Involvement}

\begin{tabular}{|c|c|c|c|c|}
\hline $\begin{array}{l}\text { Author(s) \& } \\
\text { Year }\end{array}$ & $\begin{array}{l}\text { Number } \\
\text { of } \\
\text { Google } \\
\text { Scholar } \\
\text { Citations }\end{array}$ & Method & Objective & Key Findings \\
\hline $\begin{array}{l}\text { Mitchell, A. } \\
\text { A. (1979) }\end{array}$ & 649 & $\begin{array}{l}\text { Conceptual } \\
\text { (Literature } \\
\text { Review) }\end{array}$ & $\begin{array}{l}\text { Primary objective is to develop } \\
\text { an acceptable definition of } \\
\text { involvement, valid measures of } \\
\text { it, and procedures for testing it. }\end{array}$ & $\begin{array}{l}\text { Involvement is commonly argued as } \\
\text { either a state or process and is seen as } \\
\text { an important mediator of consumer } \\
\text { behavior. Commonly defined as the } \\
\text { amount of interest in an object or } \\
\text { situation. }\end{array}$ \\
\hline $\begin{array}{l}\text { Clarke, K. \& } \\
\text { Belk, R. W. } \\
(1979)\end{array}$ & 538 & Survey & $\begin{array}{l}\text { To evaluate how product } \\
\text { involvement and situational } \\
\text { task importance impacts } \\
\text { expected consumer purchases }\end{array}$ & $\begin{array}{l}\text { Product involvement and situational } \\
\text { task importance were found to } \\
\text { increase expected purchase effort, but } \\
\text { task importance had a small impact } \\
\text { amongst high involvement products. } \\
\text { This demonstrated a ceiling effect on } \\
\text { overall involvement levels. }\end{array}$ \\
\hline $\begin{array}{l}\text { John L. } \\
\text { Lastovicka } \\
(1979)\end{array}$ & 166 & Questionnaire & $\begin{array}{l}\text { The relationship between } \\
\text { involvement and acquisition } \\
\text { behavior is studied within } \\
\text { diverse product classes. }\end{array}$ & $\begin{array}{l}\text { This study calls attention to an } \\
\text { involvement product classification } \\
\text { system that considers a segment-by- } \\
\text { segment analysis which must be } \\
\text { multifaceted. }\end{array}$ \\
\hline $\begin{array}{l}\text { Bloch, P. H. } \\
\text { (1981) }\end{array}$ & 541 & $\begin{array}{l}\text { Multi-Item } \\
\text { Scale }\end{array}$ & $\begin{array}{l}\text { To address the need for } \\
\text { credible scales that capture the } \\
\text { differences found in } \\
\text { involvement in certain product } \\
\text { classes }\end{array}$ & $\begin{array}{l}\text { While the identified measures were } \\
\text { pertinent to automobiles, product- } \\
\text { specificity should not bound its } \\
\text { practicality in enhancing involvement } \\
\text { measures. The identified measures can } \\
\text { also be pragmatic in other research } \\
\text { settings as a predictor variable or as a } \\
\text { covariate. }\end{array}$ \\
\hline $\begin{array}{l}\text { Bloch, P. H. \& } \\
\text { Richins, M. L. } \\
\text { (1983) }\end{array}$ & 1396 & $\begin{array}{l}\text { Conceptual } \\
\text { (Literature } \\
\text { Review), Model }\end{array}$ & $\begin{array}{l}\text { Present guidelines for the } \\
\text { examination of consumer } \\
\text { perceptions of product } \\
\text { importance }\end{array}$ & $\begin{array}{l}\text { Findings point that managers may } \\
\text { more efficiently execute approaches to } \\
\text { reach different market segments at } \\
\text { different points in the purchase } \\
\text { process by distinguishing consumer } \\
\text { perceptions of product importance }\end{array}$ \\
\hline $\begin{array}{l}\text { Traylor, M. B. } \\
\text { \& Joseph, W. } \\
\text { B. (1984) }\end{array}$ & 199 & $\begin{array}{l}\text { Focus Group, } \\
\text { Questionnaire }\end{array}$ & $\begin{array}{l}\text { To develop an improved } \\
\text { consumer involvement } \\
\text { measure that can be used for } \\
\text { various product categories. }\end{array}$ & $\begin{array}{l}\text { Scale represents a useful approach for } \\
\text { identifying consumer segments that } \\
\text { differ in their involvement with a } \\
\text { specific product. }\end{array}$ \\
\hline $\begin{array}{l}\text { Zaichkowsky } \\
\text { (1985) }\end{array}$ & 7323 & $\begin{array}{l}\text { Questionnaire, } \\
\text { Scales }\end{array}$ & $\begin{array}{l}\text { To develop a standardized } \\
\text { measurement of involvement } \\
\text { that includes multiple item } \\
\text { measures. }\end{array}$ & $\begin{array}{l}\text { A semantic differential scale was } \\
\text { developed and showed positive results } \\
\text { when capturing involvement over } \\
\text { three different product categories. }\end{array}$ \\
\hline
\end{tabular}




\section{A1. Key Findings from Seminal Articles on The Inception of Involvement (Cont'd)}

\begin{tabular}{|c|c|c|c|c|}
\hline $\begin{array}{l}\text { Kapferer, J. } \\
\text { N., \& Laurent, } \\
\text { G. (1985) }\end{array}$ & 3207 & Interviews & $\begin{array}{l}\text { Depending on the antecedents } \\
\text { of involvement, the outcome of } \\
\text { consumer behavior can differ. } \\
\text { Therefore, the importance of } \\
\text { measuring an involvement } \\
\text { profile, rather than a single } \\
\text { level of involvement is } \\
\text { proposed. }\end{array}$ & $\begin{array}{l}\text { An accurate forecast of the outcomes } \\
\text { of involvement cannot be estimated } \\
\text { without the antecedents stated. Hence, } \\
\text { an alternative use to the involvement } \\
\text { profile is identifying market segments } \\
\text { to further understand where } \\
\text { involvement originates. }\end{array}$ \\
\hline $\begin{array}{l}\text { Zaichkowsky } \\
\text { (1986) }\end{array}$ & 1283 & $\begin{array}{l}\text { Conceptual } \\
\text { (Literature } \\
\text { Review) }\end{array}$ & $\begin{array}{l}\text { Antecedents of involvement } \\
\text { are identified as stimulus or } \\
\text { object factors and a summary } \\
\text { of involvement and advertising } \\
\text { is provided outlining what use } \\
\text { the involvement construct } \\
\text { might have for practitioners }\end{array}$ & $\begin{array}{l}\text { In advertising, 1) consumers' reactions } \\
\text { vary for the same message due to their } \\
\text { individual values } 2 \text { ) consumers whom } \\
\text { are more involved with a message } \\
\text { provide more counterarguments } 3 \text { ) } \\
\text { consumers form assessments based on } \\
\text { different communicational cues and } \\
\text { how involved they are with the } \\
\text { subject. With products, consumers } \\
\text { perceive the same product differently. }\end{array}$ \\
\hline $\begin{array}{l}\text { Beatty, S. E.; } \\
\text { Homer, P.; } \\
\text { and Kahle, L. } \\
\text { R. (1988) }\end{array}$ & 660 & Questionnaire & $\begin{array}{l}\text { The research objective is to } \\
\text { recommend an empirically } \\
\text { tested involvement- } \\
\text { commitment model through } \\
\text { LISREL. }\end{array}$ & $\begin{array}{l}\text { The findings show the model appears } \\
\text { reasonably valid. And that ego } \\
\text { involvement is influenced by purchase } \\
\text { involvement, which is influenced by } \\
\text { brand commitment. }\end{array}$ \\
\hline $\begin{array}{l}\text { Beatty, S. E., } \\
\text { \& Kahle, L. R. } \\
(1988)\end{array}$ & 444 & Questionnaire & $\begin{array}{l}\text { To test the theory of reasoned } \\
\text { action and the low- } \\
\text { involvement hierarchy model } \\
\text { by examining the consumption } \\
\text { behaviours of a frequently } \\
\text { purchased product }\end{array}$ & $\begin{array}{l}\text { The findings did not fully accept } \\
\text { hypotheses } 1 \text { and } 2 \text {, however the } \\
\text { overall idea of the hypotheses seem to } \\
\text { be supported. Findings also found that } \\
\text { behavior was seen to influence habit in } \\
\text { individuals. }\end{array}$ \\
\hline $\begin{array}{l}\text { Mittal, B. \& } \\
\text { Lee, M.S. } \\
(1988)\end{array}$ & 181 & Questionnaire & $\begin{array}{l}\text { Authors point out two gaps in } \\
\text { Laurent and Kapferer's (1985) } \\
\text { Consumer Involvement Profile } \\
\text { a) develop scale items into full } \\
\text { scales, and b) separate product- } \\
\text { and brand-choice levels. }\end{array}$ & $\begin{array}{l}\text { The scale items proposed had strong } \\
\text { internal reliabilities for perceived } \\
\text { importance of brand choice, sign value } \\
\text { of the product, sign value of the brand, } \\
\text { and hedonic value from the product. } \\
\text { Perceived product risk, perceived } \\
\text { brand risk, and hedonic value at the } \\
\text { brand level also had good reliabilities. }\end{array}$ \\
\hline $\begin{array}{l}\text { Mittal, B. \& } \\
\text { Lee, M.S. } \\
\text { (1989) }\end{array}$ & 819 & $\begin{array}{l}\text { Empirical } \\
\text { (Structural } \\
\text { Model } \\
\text { Equation) }\end{array}$ & $\begin{array}{l}\text { Aims to distinguish product } \\
\text { involvement and brand- } \\
\text { decision involvement. }\end{array}$ & $\begin{array}{l}\text { Product involvement was accepted as } \\
\text { a significant antecedent of brand- } \\
\text { decision involvement. }\end{array}$ \\
\hline $\begin{array}{l}\text { Higie \& Feick } \\
(1989)\end{array}$ & 361 & Questionnaire & $\begin{array}{l}\text { To re-emphasize the } \\
\text { significance of enduring } \\
\text { involvement and to develop a } \\
\text { credible scale to measure } \\
\text { enduring involvement. }\end{array}$ & $\begin{array}{l}\text { Enduring involvement acts as a } \\
\text { predictor of opinion leadership and } \\
\text { information search, thus it is inapt to } \\
\text { assess enduring involvement with such } \\
\text { behaviors because these behaviors can } \\
\text { occur from other causes. }\end{array}$ \\
\hline
\end{tabular}




\section{A1. Key Findings from Seminal Articles on The Inception of Involvement (Cont'd)}

\begin{tabular}{|c|c|c|c|c|}
\hline $\begin{array}{l}\text { Andrews, J. } \\
\text { C.; Durvasula, } \\
\text { S.; and } \\
\text { Akhter, S. H. } \\
(1990)\end{array}$ & 687 & $\begin{array}{l}\text { Conceptual } \\
\text { (Literature } \\
\text { Review) }\end{array}$ & $\begin{array}{l}\text { Examine the underlying } \\
\text { properties of the involvement } \\
\text { construct }\end{array}$ & $\begin{array}{l}\text { Four streams related to involvement } \\
\text { emerged: attention/processing, } \\
\text { personal/situational involvement, } \\
\text { audience/process involvement, and } \\
\text { enduring/product involvement }\end{array}$ \\
\hline $\begin{array}{l}\text { Browne, B. A. } \\
\text { \& Kaldenberg, } \\
\text { D. O. (1997) }\end{array}$ & 374 & Scale, Survey & $\begin{array}{l}\text { To demonstrate a foundation } \\
\text { for benefit-based promotions } \\
\text { by examining high self- } \\
\text { monitors to behave like } \\
\text { opinion leaders and } \\
\text { materialists to be inclined to } \\
\text { consume. }\end{array}$ & $\begin{array}{l}\text { Results show that products that } \\
\text { symbolize status and interest } \\
\text { materialists would also appeal to high } \\
\text { self-monitors over sentimental goods. }\end{array}$ \\
\hline $\begin{array}{l}\text { Auty, S. \& } \\
\text { Elliott, R. } \\
(1998)\end{array}$ & 261 & $\begin{array}{l}\text { Focus Group, } \\
\text { Survey }\end{array}$ & $\begin{array}{l}\text { To demonstrate the } \\
\text { significance fashion } \\
\text { involvement plays in the ways } \\
\text { brands are understood in jeans } \\
\text { using Snyder's revised self- } \\
\text { monitoring scale }\end{array}$ & $\begin{array}{l}\text { Those with high fashion involvement } \\
\text { are shown to be more positive towards } \\
\text { branded jeans and negative towards } \\
\text { unbranded jeans. Generic products are } \\
\text { disregarded compared to top brands. }\end{array}$ \\
\hline $\begin{array}{l}\text { Warrington, P. } \\
\text { \& Shim, S. } \\
(2000)\end{array}$ & 432 & Questionnaire & $\begin{array}{l}\text { To examine the connection } \\
\text { amidst product involvement } \\
\text { and brand commitment }\end{array}$ & $\begin{array}{l}\text { Product involvement and brand } \\
\text { commitment signify distinct concepts. } \\
\text { Four market segments appeared based } \\
\text { upon low and high levels of product } \\
\text { involvement and brand commitment. }\end{array}$ \\
\hline $\begin{array}{l}\text { Quester, P. \& } \\
\text { Lin Lim, A. } \\
\text { (2003) }\end{array}$ & 499 & Questionnaire & $\begin{array}{l}\text { The research objective was to } \\
\text { empirically study the } \\
\text { connection between product } \\
\text { involvement and brand loyalty }\end{array}$ & $\begin{array}{l}\text { Findings show involvement differs } \\
\text { amongst sneakers and pens and that } \\
\text { product involvement and brand loyalty } \\
\text { are not universal constructs }\end{array}$ \\
\hline $\begin{array}{l}\text { Hennig- } \\
\text { Thurau, T., } \\
\text { Gwinner, K. } \\
\text { P., Walsh, G., } \\
\text { \& Gremler, D. } \\
\text { D. (2004) }\end{array}$ & 4208 & Questionnaire & $\begin{array}{l}\text { To recognize the drives that } \\
\text { propel a consumer to engage in } \\
\text { eWOM on consumer-opinion } \\
\text { platforms. }\end{array}$ & $\begin{array}{l}\text { Findings show social interaction, } \\
\text { economic incentives, concern for other } \\
\text { consumers, and the ability to raise } \\
\text { one's self-image encourages eWOM. }\end{array}$ \\
\hline $\begin{array}{l}\text { O'Cass, A. } \\
\text { (2004) }\end{array}$ & 456 & Questionnaire & $\begin{array}{l}\text { To examine the antecedents } \\
\text { and consequences of fashion } \\
\text { clothing involvement. }\end{array}$ & $\begin{array}{l}\text { Findings show that fashion } \\
\text { involvement is influenced by } \\
\text { materialism, gender and age, and that } \\
\text { fashion involvement influences } \\
\text { fashion knowledge, and consumer } \\
\text { confidence in making purchase } \\
\text { decisions. }\end{array}$ \\
\hline $\begin{array}{l}\text { Eun Joo Park, } \\
\text { Eun Young } \\
\text { Kim, Judith } \\
\text { Cardona } \\
\text { Forney (2006) }\end{array}$ & 366 & Questionnaire & $\begin{array}{l}\text { To study the relationship } \\
\text { between fashion involvement, } \\
\text { positive emotion, hedonic } \\
\text { consumption tendency, and } \\
\text { fashion-oriented impulse } \\
\text { buying. }\end{array}$ & $\begin{array}{l}\text { Fashion involvement and positive } \\
\text { emotion influenced consumers' } \\
\text { fashion-oriented impulse buying } \\
\text { behavior with fashion involvement } \\
\text { having the greatest impact. Hedonic } \\
\text { consumption tendency behaved as a } \\
\text { mediator in determining fashion- } \\
\text { oriented impulse buying. }\end{array}$ \\
\hline
\end{tabular}


A1. Key Findings from Seminal Articles on The Inception of Involvement (Cont'd)

\begin{tabular}{|l|l|l|l|l|}
\hline $\begin{array}{l}\text { Wolny \& } \\
\text { Mueller } \\
\text { (2013) }\end{array}$ & 147 & Questionnaire & $\begin{array}{l}\text { The research objective was to } \\
\text { examine consumers' exchanges } \\
\text { with fashion brands on social } \\
\text { media, concentrating on drives } \\
\text { that encourage eWOM. }\end{array}$ & $\begin{array}{l}\text { Fashion and brand involvement are the } \\
\text { key drives behind fashion brand- } \\
\text { related eWOM. High brand } \\
\text { involvement leads to engagement with } \\
\text { brands online. The level of product } \\
\text { involvement dictates admist those that } \\
\text { comment/tweet often and rarely. This } \\
\text { shows customers need to engage with } \\
\text { a product to increase eWOM }\end{array}$ \\
\hline
\end{tabular}




\section{A2: Data Construct Descriptions in Alphabetical Order}

\section{$\underline{\text { Demographics }}$}

(D1) What is your age?

(D2) Do you own jeans?

(D3) How many pairs of jeans do you own?

(D4) What is your gender?

(D5) Please select the province where you live.

(D6) How many days in a typical week do you wear jeans?

(D7) Which of the following best describes how often you buy a new pair of jeans?

(D8) How many dollars do you spend on average for a pair of jeans?

(D9) What is the most you would spend for an outstanding pair of jeans?

(D10) How many pairs of jeans have you bought in the past 12 months?

(D11) How many pairs of jeans do you typically try on before buying a single pair?

(D12) What is your current marital status?

(D13) What is the highest level of education you have completed?

(D14) Including yourself, how many people are there in your household?

(D15) Into which category does your total annual household income fall (before taxes)?

(D16) What is your ancestry or ethnic background? Check all that apply.

\section{Fashion Brand Involvement - 11 Indicators from Wolny and Mueller (2013)}

Scale- Strongly Agree $=9 /$ Strongly Disagree $=1$

Please rate how much you agree or disagree with each statement below:

(FBI1) I trust what is said by a fashion brand

(FBI2) Tweets by fashion brands influence my buying behaviour

(FBI3) Posts in social media by fashion brands influence my buying behaviour

(FBI4) I can identify with people wearing the same brands as me

(FBI5) It is very important to me to buy the right fashion brand

(FBI6) Fashion bloggers influence my buying behaviour 
(FBI7) Posts in social media by retailers influence my buying behaviour

(FBI8) Pins on Pinterest by fashionistas influence my buying behaviour (FBI9) I trust what is said by a retailer

(FBI10) Retailer tweets influence my buying behaviour

(FBI11) I invest much effort before selecting the right fashion brand

\section{Online Brand Engagement - 7 Indicators from Campbell et al. (2014)}

Scale- Strongly Agree $=7 /$ Strongly Disagree $=1$

Please rate how much you agree or disagree with each statement below:

(OBE 1) I like to talk about brands/organizations that are advertised on social networking sites

(OBE 2) I am always interested in learning more about brands/organizations that are present online

(OBE 3) I would be interested in receiving communications from a brand/organization via social networking sites

(OBE 4) I am accepting of communications from brands/organizations provided they seek my permission

(OBE 5) I am proud to have others know which brands/organizations I affiliate with via social networking sites

(OBE 6) I like to browse through social networking related to brands/organizations

(OBE 7) Compared to other people, I closely follow news about brands/organizations

\section{Other (Altruistic) Involvement - 4 Indicators from Wolny and Mueller (2013)}

Scale- Strongly Agree $=7 /$ Strongly Disagree $=1$

I write comments or posts on virtual platforms because:

(OI1) I want to help others with my positive experiences with brands

(OI2) I want to warn others with my negative experiences with brands

(OI3) I want to give others the opportunity to buy nice products

(OI4) I want to expose brands that behave badly 
Product Involvement - 4 Indicators from Wolny and Mueller (2013)

Scale- Strongly Agree $=7 /$ Strongly Disagree $=1$

I write comments on virtual platforms because:

(PI1) I can express my joy about a product

(PI2) I can express my disappointment about a product

(PI3) I feel good when I can tell others about my buying successes

(PI4) I feel good when I can tell others about my buying failures

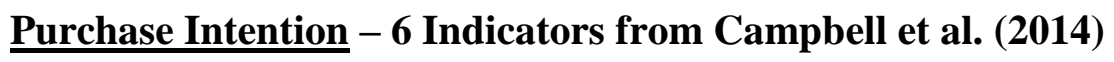

Scale- Very Likely $=9 /$ Very Unlikely $=1$

I am likely to buy products that I see...

(PR1) ...advertised on social networking sites

(PR2) ...other consumers talking about on social networking sites

(PR3) ...on social networking sites if the price is appealing

(PR4) ...on social networking sites if the delivery period is satisfactory

(PR5) ...on social networking sites if it is a brand I know and trust

(PR6) ...on social networking sites if it is a new and exciting product 
A3: Construct Reliability \& Validity Tests: Cronbach's Alpha, Composite Reliability, and Average Variance Extracted

\begin{tabular}{|c|c|c|c|c|}
\hline & $\begin{array}{l}\text { Cronbach's } \\
\text { Alpha }\end{array}$ & rho_A & $\begin{array}{l}\text { Composite } \\
\text { Reliability }\end{array}$ & $\begin{array}{l}\text { Average } \\
\text { Variance } \\
\text { Extracted } \\
\text { (AVE) }\end{array}$ \\
\hline $\begin{array}{l}\text { Fashion Brand } \\
\text { Involvement }\end{array}$ & & 1.000 & & \\
\hline $\begin{array}{l}\text { Online Brand } \\
\text { Engagement }\end{array}$ & 0.935 & 0.942 & 0.947 & 0.721 \\
\hline $\begin{array}{l}\text { Other } \\
\text { Involvement }\end{array}$ & 0.935 & 0.942 & 0.953 & 0.836 \\
\hline $\begin{array}{l}\text { Product } \\
\text { Involvement }\end{array}$ & 0.919 & 0.923 & 0.943 & 0.806 \\
\hline $\begin{array}{l}\text { Purchase } \\
\text { Intention }\end{array}$ & 0.946 & 0.947 & 0.957 & 0.789 \\
\hline
\end{tabular}


A4: Item-Total Statistics: Cronbach's Alpha If Item Deleted

\begin{tabular}{|c|c|c|c|c|c|}
\hline \multicolumn{6}{|c|}{ Item-Total Statistics } \\
\hline & $\begin{array}{l}\text { Scale Mean if } \\
\text { Item Deleted }\end{array}$ & $\begin{array}{l}\text { Scale Variance } \\
\text { if Item Deleted }\end{array}$ & $\begin{array}{l}\text { Corrected Item- } \\
\text { Total Correlation }\end{array}$ & $\begin{array}{c}\text { Squared } \\
\text { Multiple } \\
\text { Correlation }\end{array}$ & $\begin{array}{c}\text { Cronbach's } \\
\text { Alpha if Item } \\
\text { Deleted }\end{array}$ \\
\hline Q33_1VirtPlatJoy & 101.87 & 2109.383 & .683 & .780 & .969 \\
\hline Q33_2VirtPlatDisapp & 101.61 & 2117.366 & .624 & .769 & .969 \\
\hline Q33_3VirtPlatBuySucc & 101.88 & 2108.347 & .690 & .730 & .969 \\
\hline Q33_4VirtPlatBuyFail & 102.39 & 2127.297 & .633 & .624 & .969 \\
\hline Q34_1TalkBrSN & 102.89 & 2120.844 & .767 & .709 & .968 \\
\hline Q34_2InterstBrSN & 102.23 & 2117.300 & .751 & .666 & .968 \\
\hline Q34_3InterestCommBrSN & 102.68 & 2114.407 & .771 & .740 & .968 \\
\hline Q34_4AccepCommBrSN & 101.83 & 2139.671 & .561 & .505 & .969 \\
\hline Q34_5PrideAffilSN & 102.67 & 2110.286 & .797 & .746 & .968 \\
\hline Q34_6BrowseSN & 102.54 & 2102.517 & .803 & .731 & .968 \\
\hline Q34_7FollowBr & 102.85 & 2117.339 & .765 & .706 & .968 \\
\hline Q38_1PurchAdvSN & 102.35 & 2102.044 & .752 & .764 & .968 \\
\hline Q38_2PurchConsSN & 102.19 & 2098.069 & .761 & .758 & .968 \\
\hline Q38_3PurchSNPriceAppeal & 101.59 & 2076.787 & .738 & .756 & .968 \\
\hline Q38_4PurchSNDeliv & 102.24 & 2098.265 & .735 & .704 & .968 \\
\hline Q38_5PurchSNTrustBr & 101.47 & 2074.650 & .718 & .709 & .969 \\
\hline Q38_6PurchSNNewProd & 102.09 & 2084.116 & .773 & .751 & .968 \\
\hline Q39_1WriteVirHelpOth & 101.54 & 2113.126 & .681 & .813 & .969 \\
\hline Q39_2WriteVirWarnOth & 101.45 & 2128.689 & .588 & .756 & .969 \\
\hline Q39_3WriteVirGiveOpp & 101.62 & 2112.761 & .693 & .781 & .969 \\
\hline $\begin{array}{l}\text { Q39_4WriteVirExposeBadBe } \\
\text { h }\end{array}$ & 101.56 & 2128.728 & .584 & .703 & .969 \\
\hline Q31_01Trust & 101.22 & 2134.772 & .557 & .560 & .969 \\
\hline Q31_02Tweets & 102.90 & 2105.193 & .737 & .784 & .968 \\
\hline Q31_03Posts & 102.61 & 2086.408 & .784 & .810 & .968 \\
\hline Q31_04IdentifyWBr & 101.61 & 2105.150 & .635 & .539 & .969 \\
\hline Q31_05BuyRtBr & 101.95 & 2089.953 & .664 & .623 & .969 \\
\hline Q31_06FsnBloggers & 102.90 & 2096.109 & .751 & .793 & .968 \\
\hline Q31_07Posts & 102.68 & 2082.197 & .814 & .839 & .968 \\
\hline Q31_08Pins & 102.77 & 2094.732 & .709 & .692 & .969 \\
\hline Q31_09TrustRetail & 101.26 & 2147.906 & .484 & .492 & .970 \\
\hline Q31_10RetTweet & 102.95 & 2101.477 & .751 & .773 & .968 \\
\hline Q31_11EffortRtBr & 101.63 & 2088.823 & .662 & .552 & .969 \\
\hline
\end{tabular}


A5: Reliability Statistics: Average Cronbach's Alpha

\section{Reliability Statistics}

\begin{tabular}{|c|c|c|}
\hline $\begin{array}{c}\text { Cronbach's } \\
\text { Alpha }\end{array}$ & $\begin{array}{c}\text { Cronbach's } \\
\text { Alpha Based on } \\
\text { Standardized } \\
\text { Items }\end{array}$ & $\mathrm{N}$ of Items \\
\hline .970 & .970 & 32 \\
\hline
\end{tabular}




\section{A6: Reflective Constructs: Outer Loadings}

\begin{tabular}{|c|c|c|c|c|c|}
\hline \multicolumn{6}{|c|}{ Reflective Constructs: Outer Loadings } \\
\hline & Fashion Brand Involvement & Online Brand Engagement & Other Involvement & Product Involvement & Purchase Intention \\
\hline FBI1 & 0.620 & & & & \\
\hline FBI2 & 0.835 & & & & \\
\hline FBI3 & 0.890 & & & & \\
\hline FBI4 & 0.716 & & & & \\
\hline FBI5 & 0.737 & & & & \\
\hline FBI6 & 0.842 & & & & \\
\hline FBI7 & 0.933 & & & & \\
\hline FBI8 & 0.816 & & & & \\
\hline FBI9 & 0.532 & & & & \\
\hline FBI10 & 0.862 & & & & \\
\hline FBI11 & 0.752 & & & & \\
\hline PI1 & & & & 0.916 & \\
\hline PI2 & & & & 0.904 & \\
\hline PI3 & & & & 0.910 & \\
\hline PI4 & & & & 0.860 & \\
\hline OBE1 & & 0.864 & & & \\
\hline OBE2 & & 0.849 & & & \\
\hline OBE3 & & 0.883 & & & \\
\hline OBE4 & & 0.710 & & & \\
\hline OBE5 & & 0.892 & & & \\
\hline OBE6 & & 0.874 & & & \\
\hline OBE7 & & 0.859 & & & \\
\hline PUI1 & & & & & 0.888 \\
\hline PUI2 & & & & & 0.898 \\
\hline PUI3 & & & & & 0.899 \\
\hline PUI4 & & & & & 0.878 \\
\hline PUI5 & & & & & 0.865 \\
\hline PUI6 & & & & & 0.900 \\
\hline OI1 & & & 0.939 & & \\
\hline OI2 & & & 0.907 & & \\
\hline OI3 & & & 0.920 & & \\
\hline OI4 & & & 0.890 & & \\
\hline
\end{tabular}




\section{A7: Reflective Constructs: Cross Loadings}

\begin{tabular}{|c|c|c|c|c|c|}
\hline \multicolumn{6}{|c|}{ Reflective Constructs: Cross Loadings } \\
\hline & Fashion Brand Involvement & Online Brand Engagement & Other Involvement & Product Involvement & Purchase Intention \\
\hline FBI1 & 0.620 & 0.504 & 0.289 & 0.352 & 0.417 \\
\hline FBI2 & 0.835 & 0.665 & 0.394 & 0.457 & 0.590 \\
\hline FBI3 & 0.890 & 0.670 & 0.454 & 0.478 & 0.678 \\
\hline FBI4 & 0.716 & 0.552 & 0.365 & 0.418 & 0.506 \\
\hline FBI5 & 0.737 & 0.586 & 0.374 & 0.415 & 0.512 \\
\hline FBI6 & 0.842 & 0.669 & 0.420 & 0.445 & 0.609 \\
\hline FBI7 & 0.933 & 0.724 & 0.472 & 0.504 & 0.685 \\
\hline FBI8 & 0.816 & 0.637 & 0.405 & 0.445 & 0.591 \\
\hline FBI9 & 0.532 & 0.446 & 0.261 & 0.297 & 0.348 \\
\hline FBI10 & 0.862 & 0.703 & 0.405 & 0.476 & 0.588 \\
\hline FBI11 & 0.752 & 0.566 & 0.420 & 0.462 & 0.528 \\
\hline PI1 & 0.516 & 0.602 & 0.630 & 0.916 & 0.528 \\
\hline PI2 & 0.449 & 0.539 & 0.631 & 0.904 & 0.479 \\
\hline PI3 & 0.529 & 0.599 & 0.613 & 0.910 & 0.553 \\
\hline PI4 & 0.504 & 0.559 & 0.546 & 0.860 & 0.478 \\
\hline OBE1 & 0.701 & 0.864 & 0.460 & 0.539 & 0.645 \\
\hline OBE2 & 0.640 & 0.849 & 0.534 & 0.564 & 0.625 \\
\hline OBE3 & 0.665 & 0.883 & 0.507 & 0.556 & 0.661 \\
\hline OBE4 & 0.441 & 0.710 & 0.430 & 0.443 & 0.454 \\
\hline OBE5 & 0.699 & 0.892 & 0.537 & 0.598 & 0.655 \\
\hline OBE6 & 0.713 & 0.874 & 0.537 & 0.589 & 0.706 \\
\hline OBE7 & 0.716 & 0.859 & 0.477 & 0.513 & 0.616 \\
\hline PUI1 & 0.679 & 0.665 & 0.456 & 0.473 & 0.888 \\
\hline PUI2 & 0.657 & 0.668 & 0.499 & 0.508 & 0.898 \\
\hline PUI3 & 0.604 & 0.650 & 0.541 & 0.509 & 0.899 \\
\hline PUI4 & 0.639 & 0.655 & 0.474 & 0.489 & 0.878 \\
\hline PUI5 & 0.587 & 0.621 & 0.538 & 0.523 & 0.865 \\
\hline PUI6 & 0.657 & 0.684 & 0.513 & 0.531 & 0.900 \\
\hline OI1 & 0.499 & 0.568 & 0.939 & 0.650 & 0.553 \\
\hline OI2 & 0.415 & 0.475 & 0.907 & 0.595 & 0.463 \\
\hline $\mathrm{OI} 3$ & 0.515 & 0.597 & 0.920 & 0.641 & 0.569 \\
\hline OI4 & 0.400 & 0.487 & 0.890 & 0.571 & 0.474 \\
\hline
\end{tabular}




\section{A8: Reflective Constructs: Fornell-Larcker Criterion}

Fornell-Larcker Criterion

\begin{tabular}{|l|r|r|r|r|r|}
\hline & Fashion Brand Involvement & Online Brand Engagement & Other Involvement & Product Involvement & Purchase Intention \\
\hline Fashion Brand Involvement & & & & & \\
\hline Online Brand Engagement & 0.778 & 0.849 & & & \\
\hline Other Involvement & 0.505 & 0.586 & 0.914 & & \\
\hline Product Involvement & 0.558 & 0.642 & 0.674 & 0.898 & \\
\hline Purchase Intention & 0.718 & 0.740 & 0.567 & & 0.569 \\
\hline
\end{tabular}




\section{A9: Reflective Constructs: HTMT Ratio Confidence Intervals Bias Corrected}

Heterotrait-Monotrait Ratio (HTMT): Confidence Intervals Bias Corrected

\begin{tabular}{|l|r|r|r|r|r|}
\hline & Original Sample (O) & Sample Mean (M) & Bias & $2.50 \%$ & $97.50 \%$ \\
\hline Other Involvement -> Online Brand Engagement & 0.623 & 0.623 & -0.000 & 0.570 & 0.668 \\
\hline Product Involvement -> Online Brand Engagement & 0.689 & 0.689 & 0.000 & 0.75 & 0.734 \\
\hline Product Involvement -> Other Involvement & 0.725 & 0.725 & -0.000 & 0.000 & 0.676 \\
\hline Purchase Intention -> Online Brand Engagement & 0.781 & 0.781 & -0.000 & 0.772 \\
\hline Purchase Intention -> Other Involvement & 0.598 & 0.598 & -0.001 & 0.818 \\
\hline Purchase Intention -> Product Involvement & 0.608 & 0.608 & 0.000 & 0.547 & 0.646 \\
\hline
\end{tabular}


A10: Reflective Measurement Model: Summary of Results

\begin{tabular}{|c|c|c|c|c|c|c|c|}
\hline \multicolumn{8}{|c|}{ SUMMARY OF RESULTS: REFLECTIVE MEASUREMENT MODELS } \\
\hline \multirow{3}{*}{ Latent Variable } & \multirow{3}{*}{ Indicators } & \multicolumn{3}{|c|}{ Convergent Validity } & \multicolumn{2}{|c|}{ Internal Consistency Reliability } & \multirow[t]{2}{*}{ Discriminant Validity } \\
\hline & & Loadings & Indicator Reliability & AVE & Composite Reliability & Cronbach's Alpha & \\
\hline & & $>0.70$ & $>0.50$ & $>0.50$ & $0.60-0.90$ & $0.60-0.90$ & $\begin{array}{c}\text { HTMT Confidence } \\
\text { Interval Does Not } \\
\text { Include } 1 \\
\end{array}$ \\
\hline \multirow{4}{*}{ Product Involvement } & PI1 & 0.916 & 0.839 & \multirow{4}{*}{0.806} & \multirow{4}{*}{0.943} & \multirow{4}{*}{0.919} & \multirow{4}{*}{ Yes } \\
\hline & PI2 & 0.904 & 0.817 & & & & \\
\hline & PI3 & 0.910 & 0.828 & & & & \\
\hline & PI4 & 0.860 & 0.740 & & & & \\
\hline \multirow{7}{*}{ Online Brand Engagement } & OBE1 & 0.864 & 0.747 & \multirow{7}{*}{0.721} & \multirow{7}{*}{0.947} & \multirow{7}{*}{0.935} & \multirow{7}{*}{ Yes } \\
\hline & OBE2 & 0.849 & 0.721 & & & & \\
\hline & OBE3 & 0.883 & 0.780 & & & & \\
\hline & OBE4 & 0.710 & 0.504 & & & & \\
\hline & OBE5 & 0.892 & 0.796 & & & & \\
\hline & OBE6 & 0.874 & 0.763 & & & & \\
\hline & OBE7 & 0.859 & 0.737 & & & & \\
\hline \multirow{6}{*}{ Purchase Intention } & PUI1 & 0.888 & 0.789 & \multirow{6}{*}{0.789} & \multirow{6}{*}{0.957} & \multirow{6}{*}{0.946} & \multirow{6}{*}{ Yes } \\
\hline & PUI2 & 0.898 & 0.806 & & & & \\
\hline & PUI3 & 0.899 & 0.808 & & & & \\
\hline & PUI4 & 0.878 & 0.772 & & & & \\
\hline & PUI5 & 0.865 & 0.748 & & & & \\
\hline & PUI6 & 0.900 & 0.809 & & & & \\
\hline \multirow{4}{*}{ Altruistic Involvement } & AI1 & 0.939 & 0.882 & \multirow{4}{*}{0.836} & \multirow{4}{*}{0.953} & \multirow{4}{*}{0.935} & \multirow{4}{*}{ Yes } \\
\hline & AI2 & 0.907 & 0.823 & & & & \\
\hline & $\mathrm{AI} 3$ & 0.920 & 0.846 & & & & \\
\hline & AI4 & 0.890 & 0.792 & & & & \\
\hline
\end{tabular}


A11: Formative Constructs: Redundancy Analysis

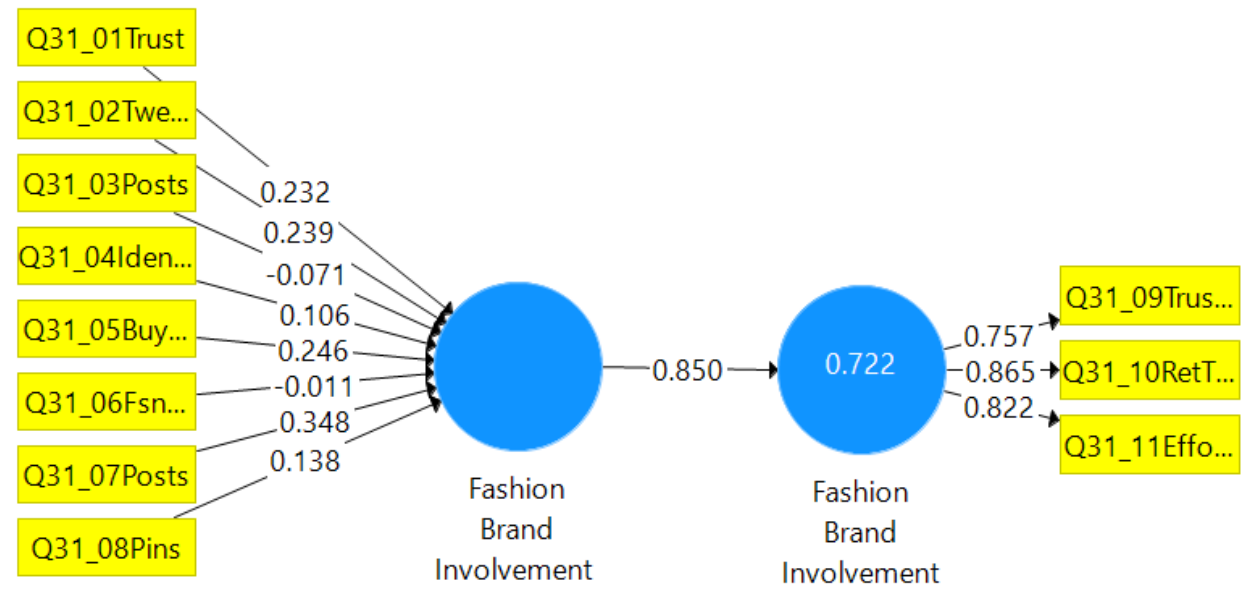


A12: Formative Constructs: VIF Values

\begin{tabular}{|c|c|}
\hline Formative Indicator & VIF \\
\hline FBI1 & 2.177 \\
\hline FBI2 & 4.419 \\
\hline FBI3 & 4.898 \\
\hline FBI4 & 2.031 \\
\hline FBI5 & 2.525 \\
\hline FBI6 & 4.540 \\
\hline FBI7 & 5.668 \\
\hline FBI8 & 3.098 \\
\hline FBI9 & 1.891 \\
\hline FBI10 & 4.022 \\
\hline FBI11 & 2.075 \\
\hline
\end{tabular}


A13: Formative Measurement Model: Summary of Results

\begin{tabular}{|c|c|c|c|c|c|c|}
\hline \multicolumn{7}{|c|}{ SUMMARY OF RESULTS: FORMATIVE MEASUREMENT MODELS } \\
\hline $\begin{array}{l}\text { Formative } \\
\text { Constructs }\end{array}$ & $\begin{array}{l}\text { Formative } \\
\text { Indicators }\end{array}$ & $\begin{array}{c}\text { Outer Weights } \\
\text { (Outer Loadings) }\end{array}$ & t Value & $\mathrm{p}$ Value & $\begin{array}{c}95 \% \mathrm{BCa} \\
\text { Confidence } \\
\text { Interval }\end{array}$ & $\begin{array}{l}\text { Significance } \\
(\mathrm{p}<0.05) ?\end{array}$ \\
\hline \multirow{10}{*}{ FBI } & FBI1 & $0.075(0.626)$ & 1.504 & 0.133 & {$[-0.021,0.171]$} & No \\
\hline & FBI2 & $0.030(0.844)$ & 0.493 & 0.622 & {$[-0.088,0.156]$} & No \\
\hline & FBI3 & $0.283(0.899)$ & 4.646 & 0.000 & {$[0.166,0.406]$} & Yes \\
\hline & FBI4 & $0.122(0.724)$ & 2.678 & 0.007 & {$[0.039,0.218]$} & Yes \\
\hline & FBI5 & $0.041(0.744)$ & 0.849 & 0.396 & {$[-0.057,0.133]$} & No \\
\hline & FBI6 & $0.043(0.851)$ & 0.730 & 0.466 & {$[-0.075,0.156]$} & No \\
\hline & FBI8 & $0.175(0.824)$ & 3.392 & 0.001 & {$[0.074,0.275]$} & Yes \\
\hline & FBI9 & $-0.001(0.538)$ & 0.011 & 0.991 & {$[-0.088,0.088]$} & No \\
\hline & FBI10 & $0.258(0.871)$ & 4.365 & 0.000 & {$[0.142,0.372]$} & Yes \\
\hline & FBI11 & $0.196(0.760)$ & 4.320 & 0.000 & {$[0.112,0.290]$} & Yes \\
\hline
\end{tabular}




\section{A14: Construct Cross-Validated Redundancy Scores}

Construct Crossvalidated Redundancy

\begin{tabular}{|c|c|c|c|c|c|}
\hline \multirow{2}{*}{\multicolumn{2}{|c|}{ Total }} & \multirow[t]{2}{*}{ Case3 } & Case6 Case7 & \multirow[b]{2}{*}{ SSE } & \multirow[b]{2}{*}{$Q^{2}(=1$-SSE/SSO) } \\
\hline & & & sso & & \\
\hline Fashio & Brand Involvement & & $7,990.000$ & $6,630.697$ & 0.170 \\
\hline Online & rand Engagement & & $5,593.000$ & $3,376.111$ & 0.396 \\
\hline Other I & volvement & & $3,196.000$ & $2,395.291$ & 0.251 \\
\hline Produc & Involvement & & $3,196.000$ & $3,196.000$ & \\
\hline Purcha & e Intention & & $4,794.000$ & $2,662.295$ & 0.445 \\
\hline
\end{tabular}




\section{References}

Aaker, J., Fournier, S., \& Brasel, S. A. (2004). When good brands do bad. Journal of Consumer research, 31(1), 1-16.

Abdullah, \& Siraj, S. (2018). Antecedents and consequences of the process of customer engagement through social media: an integrated conceptual framework. International Journal of Electronic Business, 14(1), 1-27.

Adenan, M. A., Ali, J. K., \& Rahman, D. H. A. A. (2018). Country of origin, brand image and high involvement product towards customer purchase intention: empirical evidence of east malaysian consumer. Jurnal Manajemen dan Kewirausahaan, 20(1), 63-72.

Agudo-Peregrina, Á. F., Chaparro-Peláez, J., \& Pascual-Miguel, F. J. (2014). Revisiting the SEC classification framework in traditional and electronic commerce. In Managing Complexity (pp. 243-250): Springer.

Ahuvia, A. C. (2005). Beyond the extended self: Loved objects and consumers' identity narratives. Journal of consumer research, 32(1), 171-184.

Ajzen, I., \& Fishbein, M. (1980). Understanding attitudes and predicting social behaviour.

Al-Maghrabi, T., Dennis, C., Halliday, S. V., \& BinAli, A. (2011). Determinants of customer continuance intention of online shopping. International Journal of Business Science \& Applied Management (IJBSAM), 6(1), 41-66.

Appelbaum, A. (2001). The constant customer. Gallup Management Journal, 1(2), 5.

Ash, A., \& Shwartz, M. (1999). R2: a useful measure of model performance when predicting a dichotomous outcome. Statistics in medicine, 18(4), 375-384.

Auty, S., \& Elliott, R. (1998). Fashion involvement, self-monitoring and the meaning of brands. Journal of Product \& Brand Management, 7(2), 109-123.

Babin, \& Harris. (2012). Cb4: Cengage Learning.

Babin, Murray, \& Harris. (2017). CB: Consumer behaviour: Nelson Education Limited.

Babin, B. J., Murray, K. B., \& Harris, E. G. (2017). CB: Consumer behaviour: Nelson Education Limited.

Bagozzi, R. P., \& Dholakia, U. M. (2006). Antecedents and purchase consequences of customer participation in small group brand communities. International Journal of Research in Marketing, 23(1), 45-61. doi:10.1016/j.ijresmar.2006.01.005

Bai, Y., Yao, Z., \& Dou, Y.-F. (2015). Effect of social commerce factors on user purchase behavior: An empirical investigation from renren. com. International Journal of Information Management, 35(5), 538-550.

Balakrishnan, B. K., Dahnil, M. I., \& Yi, W. J. (2014). The impact of social media marketing medium toward purchase intention and brand loyalty among generation Y. Procedia-Social and Behavioral Sciences, 148, 177-185.

Bassey, M. (1995). Creating education through research: a global perspective of educational research for the 21st century: Kirklington Moor Press in conjunction with the British Educational Research Association.

Batson, C. D., Ahmad, N., \& Tsang, J. A. (2002). Four motives for community involvement. Journal of Social Issues, 58(3), 429-445.

Becker, J.-M., Rai, A., Ringle, C. M., \& Völckner, F. (2013). Discovering Unobserved Heterogeneity in Structural Equation Models to Avert Validity Threats. Mis Quarterly, 37(3), 665-694.

Berman, B. (2005). How to delight your customers. California Management Review, 48(1), 129-151. 
Bickart, B., \& Schindler, R. M. (2001). Internet forums as influential sources of consumer information. Journal of interactive marketing, 15(3), 31-40.

Blaikie, N. (2009). Designing social research: Polity.

Bloch, P. H. (1981). An exploration into the scaling of consumers' involvement with a product class. $A C R$ North American Advances.

Bloch, P. H. (1986). The product enthusiast: Implications for marketing strategy. Journal of Consumer Marketing, 3(3), 51-62.

Bock, G.-W., Zmud, R. W., Kim, Y.-G., \& Lee, J.-N. (2005). Behavioral intention formation in knowledge sharing: Examining the roles of extrinsic motivators, social-psychological forces, and organizational climate. MIS quarterly, 87-111.

Bollen, K. A., \& Bauldry, S. (2011). Three Cs in measurement models: Causal indicators, composite indicators, and covariates. Psychological methods, 16(3), 265.

Bolton, R. N. (2011). Comment: Customer engagement: Opportunities and challenges for organizations. Journal of Service Research, 14(3), 272-274.

Bowden, J. L.-H. (2009). The process of customer engagement: A conceptual framework. Journal of Marketing Theory and Practice, 17(1), 63-74.

Brodie, Hollebeek, L. D., Juric, B., \& Ilic, A. (2011). Customer Engagement: Conceptual Domain, Fundamental Propositions, and Implications for Research. Journal of Service Research, 14(3), 252-271. doi:10.1177/1094670511411703

Brodie, R. J., Hollebeek, L. D., Juric, B., \& Ilic, A. (2011). Customer Engagement: Conceptual Domain, Fundamental Propositions, and Implications for Research. Journal of Service Research, 14(3), 252-271. doi:10.1177/1094670511411703

Bronner, F., \& de Hoog, R. (2010). Consumer-generated versus marketer-generated websites in consumer decision making. International Journal of Market Research, 52(2), 231-248. doi:10.2501/S1470785309201193

Burnkrant, R. E., \& Sawyer, A. G. (1983). Effects of involvement and message content on informationprocessing intensity. Information processing research in advertising, 12(2), 46-64.

Calder, B. J., Malthouse, E. C., \& Schaedel, U. (2009). An Experimental Study of the Relationship between Online Engagement and Advertising Effectiveness. Journal of Interactive Marketing, 23(4), 321331. doi:10.1016/j.intmar.2009.07.002

Campbell, C., Ferraro, C., \& Sands, S. (2014). Segmenting consumer reactions to social network marketing. European Journal of Marketing, 48(3/4), 432-452. doi:10.1108/EJM-03-2012-0165

Carson, D., Gilmore, A., Perry, C., \& Gronhaug, K. (2001). Qualitative marketing research: Sage.

Cartner-Morley, J. (2015). Instagram: welcome to fashion's new front row. The Guardian.

Casteleyn, J., Mottart, A., \& Rutten, K. (2009). How to use Facebook in your market research. International Journal of Market Research, 51(4), 1-8.

Celsi, R. L., \& Olson, J. C. (1988). The role of involvement in attention and comprehension processes. Journal of consumer research, 15(2), 210-224.

Chakravarti, A., \& Janiszewski, C. (2003). The influence of macro-level motives on consideration set composition in novel purchase situations. Journal of Consumer Research, 30(2), 244-258.

Chandon, P., Morwitz, V. G., \& Reinartz, W. J. (2005). Do intentions really predict behavior? Selfgenerated validity effects in survey research. Journal of Marketing, 69(2), 1-14.

Chang, H. H., \& Chuang, S.-S. (2011). Social capital and individual motivations on knowledge sharing: Participant involvement as a moderator. Information \& management, 48(1), 9-18.

Chaudhuri, A., \& Holbrook, M. B. (2001). The chain of effects from brand trust and brand affect to brand performance: the role of brand loyalty. Journal of marketing, 65(2), 81-93. 
Cheng, M. (2018). How 2 Guys With No Fashion Experience Built a Billion-Dollar Clothing Company for Millennial Women. Retrieved from https://www.inc.com/michelle-cheng/how-revolve-has-builta-billion-dollar-fashion-company-for-millennial-women.html

Chevalier, J. A., \& Mayzlin, D. (2006). The effect of word of mouth on sales: Online book reviews. Journal of marketing research, 43(3), 345-354.

Chin, W. (2003). PLS Graph 3.0. Soft Modeling Inc., Houston.

Clarke, K., \& Belk, R. W. (1979). The effects of product involvement and task definition on anticipated consumer effort. ACR North American Advances.

Coelho, P. S., Rita, P., \& Santos, Z. R. (2018). On the relationship between consumer-brand identification, brand community, and brand loyalty. Journal of Retailing and Consumer Services, 43, 101-110.

Cohen, L., Manion, L., \& Morrison, K. (2000). Research Methods in Education, 5th edn (Abingdon: RoutledgeFalmer).

Coltman, T., Devinney, T. M., Midgley, D. F., \& Venaik, S. (2008). Formative versus reflective measurement models: Two applications of formative measurement. Journal of Business Research, 61(12), 1250-1262.

Colton, J. A., \& Bower, K. M. (2002). Some misconceptions about R2. International Society of Six Sigma Professionals, EXTRAOrdinary Sense, 3(2), 20-22.

Correa, T., Hinsley, A. W., \& De Zuniga, H. G. (2010). Who interacts on the Web?: The intersection of users' personality and social media use. Computers in Human Behavior, 26(2), 247-253.

Cui, G., Lui, H.-K., \& Guo, X. (2012). The effect of online consumer reviews on new product sales. International Journal of Electronic Commerce, 17(1), 39-58.

D. Hollebeek, L., \& Chen, T. (2014). Exploring positively-versus negatively-valenced brand engagement: a conceptual model. Journal of Product \& Brand Management, 23(1), 62-74.

Das, G., Agarwal, J., Malhotra, N. K., \& Varshneya, G. (2019). Does brand experience translate into brand commitment?: A mediated-moderation model of brand passion and perceived brand ethicality. Journal of Business Research, 95, 479-490.

Davis Mersey, R., Malthouse, E. C., \& Calder, B. J. (2010). Engagement with online media. Journal of Media Business Studies, 7(2), 39-56.

Deeter-Schmelz, D. R., Moore, J. N., \& Goebel, D. J. (2000). Prestige clothing shopping by consumers: a confirmatory assessment and refinement of the PRECON scale with managerial implications. Journal of Marketing Theory and Practice, 8(4), 43-58.

Denzin, N. K., \& Lincoln, Y. S. (2005). The Sage handbook of qualitative research: Sage Publications Ltd.

DeRose, K. (2005). What is epistemology. A brief introduction to the topic, 20.

Dessart, L., Veloutsou, C., \& Morgan-Thomas, A. (2015). Consumer engagement in online brand communities: a social media perspective. Journal of Product \& Brand Management, 24(1), 28-42.

Diamantopoulos, A. (2006). The error term in formative measurement models: interpretation and modeling implications. Journal of Modelling in Management, 1(1), 7-17.

Diamantopoulos, A., \& Winklhofer, H. M. (2001). Index construction with formative indicators: An alternative to scale development. Journal of marketing research, 38(2), 269-277.

Dichter, E. (1966). How word-of-mouth advertising works. Harvard business review, 44(6), 147-160.

Dodds, W. B., Monroe, K. B., \& Grewal, D. (1991). Effects of price, brand, and store information on buyers' product evaluations. Journal of marketing research, 307-319.

Edwards, J. R., \& Bagozzi, R. P. (2000). On the nature and direction of relationships between constructs and measures. Psychological methods, 5(2), 155.

Eisingerich, A. B., \& Rubera, G. (2010). Drivers of brand commitment: A cross-national investigation. Journal of International Marketing, 18(2), 64-79.

Elliott, R., \& Wattanasuwan, K. (1998). Consumption and the Symbolic Project of the Self. ACR European Advances. 
Ellison, N. B., Steinfield, C., \& Lampe, C. (2007). The benefits of Facebook "friends:" Social capital and college students' use of online social network sites. Journal of Computer-Mediated Communication, 12(4), 1143-1168.

Engel, J., Blackwell, R., \& Miniard, P. (2001). Harcourt broke Jovanovich college publishers, Consumer Behavior, The Dryden Press.

Enginkaya, E., \& Yılmaz, H. (2014). What drives consumers to interact with brands through social media? A motivation scale development study. Procedia-Social and Behavioral Sciences, 148, 219-226.

Ephron, E. (2006). Want engagement? Make a more engaging ad. In.

Erdoğmuş, í. E., \& Tatar, Ş. B. (2015). Drivers of Social Commerce through Brand Engagement. ProcediaSocial and Behavioral Sciences, 207, 189-195.

Esch, F.-R., Langner, T., Schmitt, B. H., \& Geus, P. (2006). Are brands forever? How brand knowledge and relationships affect current and future purchases. Journal of Product \& Brand Management, 15(2), 98-105.

Euromonitor International. (2015). Internet Retailing in the US Category Briefing. Retrieved from http://www.euromonitor.com/internet-retailing-in-the-us/report

Evrard, Y., \& Aurier, P. (1996). Identification and validation of the components of the person-object relationship. Journal of business research, 37(2), 127-134.

Fairhurst, A. E., Good, L. K., \& Gentry, J. W. (1989). Fashion involvement: An instrument validation procedure. Clothing and textiles research journal, 7(3), 10-14.

Farhi, P. (2009). The Twitter explosion: whether they are reporting about it, finding sources on it or urging viewers, listeners and readers to follow them on it, journalists just can't seem to get enough of the social networking service. Just how effective is it as a journalism tool? American journalism review, 31(3), 26-32.

Field, A. (2009). Discovering statistics using SPSS: Sage publications.

Fiore, A. M., \& Jin, H.-J. (2003). Influence of image interactivity on approach responses towards an online retailer. Internet Research, 13(1), 38-48.

Fırat, A. F., \& Dholakia, N. (2006). Theoretical and philosophical implications of postmodern debates: some challenges to modern marketing. Marketing theory, 6(2), 123-162.

Flynn, L. R., Goldsmith, R. E., \& Eastman, J. K. (1996). Opinion leaders and opinion seekers: Two new measurement scales. Journal of the Academy of Marketing Science, 24(2), 137-147.

Fornell, C., \& Bookstein, F. L. (1982). Two structural equation models: LISREL and PLS applied to consumer exit-voice theory. Journal of Marketing research, 440-452.

Fournier, S. (1998). Consumers and their brands: Developing relationship theory in consumer research. Journal of consumer research, 24(4), 343-373.

Fu, J.-R. (2006). VisualPLS-Partial Least Square (PLS) Regression-An Enhanced GUI for LVPLS (PLS 1.8 PC) Version 1.04. National Kaohsiung University of Applied Sciences, Taiwan. URL http://www2. kuas. edu. tw/prof/fred/vpls.

Gambetti, R. C., \& Graffigna, G. (2010). The concept of engagement. International Journal of Market Research, 52(6), 801-826.

Gane, M. (2006). Auguste Comte: Routledge.

Gatignon, H., \& Robertson, T. S. (1985). A propositional inventory for new diffusion research. Journal of consumer research, 11(4), 849-867.

Geissinger, A., \& Laurell, C. (2016). User engagement in social media-an explorative study of Swedish fashion brands. Journal of Fashion Marketing and Management, 20(2), 177-190.

Gensler, S., Völckner, F., Liu-Thompkins, Y., \& Wiertz, C. (2013). Managing brands in the social media environment. Journal of interactive marketing, 27(4), 242-256.

Gershoff, A. D., \& Johar, G. V. (2006). Do you know me? Consumer calibration of friends' knowledge. Journal of Consumer Research, 32(4), 496-503. 
Giovannini, S., Xu, Y., \& Thomas, J. (2015). Luxury fashion consumption and Generation Y consumers: Self, brand consciousness, and consumption motivations. Journal of Fashion Marketing and Management, 19(1), 22-40.

Goh, K.-Y., Heng, C.-S., \& Lin, Z. (2013). Social media brand community and consumer behavior: Quantifying the relative impact of user-and marketer-generated content. Information Systems Research, 24(1), 88-107.

Goldsmith, R. E., \& Clark, R. A. (2008). An analysis of factors affecting fashion opinion leadership and fashion opinion seeking. Journal of Fashion Marketing and Management: An International Journal, 12(3), 308-322.

Goldsmith, R. E., \& Horowitz, D. (2006). Measuring motivations for online opinion seeking. Journal of interactive advertising, 6(2), 2-14.

Goldsmith, R. E., Moore, M. A., \& Beaudoin, P. (1999). Fashion innovativeness and self-concept: a replication. Journal of Product \& Brand Management, 8(1), 7-18.

Grant, I. J., \& Stephen, G. R. (2005). Buying behaviour of "tweenage" girls and key societal communicating factors influencing their purchasing of fashion clothing. Journal of Fashion Marketing and Management: An International Journal, 9(4), 450-467. doi:10.1108/13612020510620812

Gronow, J. (1993). Taste and fashion: the social function of fashion and style. Acta Sociologica, 36(2), 89100.

Gudergan, S. P., Ringle, C. M., Wende, S., \& Will, A. (2008). Confirmatory tetrad analysis in PLS path modeling. Journal of business research, 61(12), 1238-1249.

Gummerus, J., Liljander, V., Weman, E., \& Pihlström, M. (2012). Customer engagement in a Facebook brand community. Management Research Review, 35(9), 857-877.

Hair, Ringle, \& Sarstedt. (2011). PLS-SEM: Indeed a silver bullet. Journal of Marketing theory and Practice, 19(2), 139-152.

Hair, Ringle, \& Sarstedt. (2013). Partial least squares structural equation modeling: Rigorous applications, better results and higher acceptance.

Hair, Sarstedt, Ringle, \& Mena. (2012). An assessment of the use of partial least squares structural equation modeling in marketing research. Journal of the academy of marketing science, 40(3), 414-433.

Hair, J. F., Ringle, C. M., \& Sarstedt, M. (2011). PLS-SEM: Indeed a silver bullet. Journal of Marketing theory and Practice, 19(2), 139-152.

Hair Jr, J. F., Hult, G. T. M., Ringle, C., \& Sarstedt, M. (2016). A primer on partial least squares structural equation modeling (PLS-SEM): Sage Publications.

Hair Jr, J. F., Sarstedt, M., Ringle, C. M., \& Gudergan, S. P. (2017). Advanced issues in partial least squares structural equation modeling: SAGE Publications.

Harvey, B. (1997). The expanded ARF model: Bridge to the accountable advertising future. Journal of Advertising Research, 37, 11-20.

Hayes, J. L., \& King, K. W. (2014). The social exchange of viral ads: Referral and coreferral of ads among college students. Journal of Interactive Advertising, 14(2), 98-109.

Hayes, J. L., King, K. W., \& Ramirez Jr, A. (2016). Brands, friends, \& viral advertising: A social exchange perspective on the ad referral processes. Journal of Interactive Marketing, 36, 31-45.

Hennig-Thurau, T., Gwinner, K. P., Walsh, G., \& Gremler, D. D. (2004). Electronic word-of-mouth via consumer-opinion platforms: what motivates consumers to articulate themselves on the internet? Journal of interactive marketing, 18(1), 38-52.

Hennig-Thurau, T., Malthouse, E. C., Friege, C., Gensler, S., Lobschat, L., Rangaswamy, A., \& Skiera, B. (2010). The impact of new media on customer relationships. Journal of service research, 13(3), 311-330. 
Henseler, J. (2010). On the convergence of the partial least squares path modeling algorithm. Computational statistics, 25(1), 107-120.

Henseler, J., \& Dijkstra, T. (2015). ADANCO 1.1. Composite Modeling, Kleve.[Google Scholar].

Henseler, J., Ringle, C. M., \& Sarstedt, M. (2015). A new criterion for assessing discriminant validity in variance-based structural equation modeling. Journal of the academy of marketing science, 43(1), 115-135.

Hess, J., \& Story, J. (2005). Trust-based commitment: multidimensional consumer-brand relationships. Journal of Consumer Marketing, 22(6), 313-322.

Ho, J. Y., \& Dempsey, M. (2010). Viral marketing: Motivations to forward online content. Journal of Business research, 63(9-10), 1000-1006.

Hoffman, D. L., \& Novak, T. P. (1996). Marketing in hypermedia computer-mediated environments: Conceptual foundations. The Journal of Marketing, 50-68.

Hollebeek. (2011). Demystifying customer brand engagement: Exploring the loyalty nexus. Journal of marketing management, 27(7-8), 785-807.

Hollebeek, L. (2011). Exploring customer brand engagement: definition and themes. Journal of strategic Marketing, 19(7), 555-573.

Hollebeek, L. D. (2011). Demystifying customer brand engagement: Exploring the loyalty nexus. Journal of marketing management, 27(7-8), 785-807.

Hollebeek, L. D., Glynn, M. S., \& Brodie, R. J. (2014). Consumer brand engagement in social media: Conceptualization, scale development and validation. Journal of interactive marketing, 28(2), 149-165.

Hollebeek, L. D., Jaeger, S. R., Brodie, R. J., \& Balemi, A. (2007). The influence of involvement on purchase intention for new world wine. Food Quality and Preference, 18(8), 1033-1049.

Holman, R. H. (1980). Clothing as communication: an empirical investigation. ACR North American Advances.

Houston, M. B., \& Walker, B. A. (1996). Self-relevance and purchase goals: mapping a consumer decision. Journal of the Academy of Marketing Science, 24(3), 232-245.

Hsu, C.-L., \& Lin, J. C.-C. (2008). Acceptance of blog usage: The roles of technology acceptance, social influence and knowledge sharing motivation. Information \& management, 45(1), 65-74.

Huang, C.-Y., Chou, C.-J., \& Lin, P.-C. (2010). Involvement theory in constructing bloggers' intention to purchase travel products. Tourism Management, 31(4), 513-526.

Hubona, G. (Producer). (2015). PLS-GUI.

Hunt, S. D. (2019). The ethics of branding, customer-brand relationships, brand-equity strategy, and branding as a societal institution. Journal of Business Research, 95, 408-416.

Hustvedt, G., \& Dickson, M. A. (2009). Consumer likelihood of purchasing organic cotton apparel: Influence of attitudes and self-identity. Journal of Fashion Marketing and Management: An International Journal, 13(1), 49-65.

Hutter, K., Hautz, J., Dennhardt, S., \& Füller, J. (2013). The impact of user interactions in social media on brand awareness and purchase intention: the case of MINI on Facebook. Journal of Product \& Brand Management, 22(5/6), 342-351.

Jamieson, L. F., \& Bass, F. M. (1989). Adjusting stated intention measures to predict trial purchase of new products: A comparison of models and methods. Journal of Marketing Research, 26(3), 336345.

Jarvis, C. B., MacKenzie, S. B., \& Podsakoff, P. M. (2003). A critical review of construct indicators and measurement model misspecification in marketing and consumer research. Journal of consumer research, 30(2), 199-218.

Joyner, R. L., Rouse, W. A., \& Glatthorn, A. A. (2018). Writing the winning thesis or dissertation: A stepby-step guide: Corwin Press. 
Kapferer, J. (2008). The New Strategic Brand Management: Creating and Sustaining Brand Equity Long Term 4th edition (New Strategic Brand Management: Creating \& Sustaining Brand Equity). In: Kogan Page.

Kapferer, J.-N., \& Laurent, G. (1985). Consumer involvement profiles: a new and practical approach to consumer involvement. Retrieved from

Keller, K. L. (1993). Conceptualizing, measuring, and managing customer-based brand equity. the Journal of Marketing, 1-22.

Keller, K. L., Parameswaran, M., \& Jacob, I. (2011). Strategic brand management: Building, measuring, and managing brand equity: Pearson Education India.

Khare, A., \& Rakesh, S. (2010). Predictors of fashion clothing involvement among Indian youth. Journal of Targeting, Measurement and Analysis for marketing, 18(3-4), 209-220.

Kim, Bae, Z.-T., \& Kang, S. H. (2008). The role of online brand community in new product development: Case studies on digital product manufacturers in Korea. International Journal of Innovation Management, 12(03), 357-376.

Kim, \& Johnson. (2016). Power of consumers using social media: Examining the influences of brandrelated user-generated content on Facebook. Computers in Human Behavior, 58, 98-108. doi:10.1016/j.chb.2015.12.047

Kim, \& Ko. (2012). Do social media marketing activities enhance customer equity? An empirical study of luxury fashion brand. Journal of Business Research, 65(10), 1480-1486.

Kim, Park, J., \& Glovinsky, P. L. (2018). Customer involvement, fashion consciousness, and loyalty for fast-fashion retailers. Journal of Fashion Marketing and Management: An International Journal.

Kim, \& Sullivan. (2019). Emotional branding speaks to consumers' heart: the case of fashion brands. Fashion and Textiles, 6(1), 2.

Kim, J., \& Forsythe, S. (2009). Adoption of sensory enabling technology for online apparel shopping. European Journal of Marketing, 43(9/10), 1101-1120.

Kock, N. (2015). WarpPLS. In.

Kohli, C., \& Thakor, M. (1997). Branding Consumer Goods: Insights from Theory and Practice Journal of Consumer Marketing 14 No. 3. In: MCB University Press.

Kotler, P., \& Bliemel, F. (2001). Marketing-Management, Stuttgart, 2001. Google Scholar.

Kotler, P., \& Gertner, D. (2002). Country as brand, product, and beyond: A place marketing and brand management perspective. Journal of brand management, 9(4), 249-261.

Kozinets, R. V., De Valck, K., Wojnicki, A. C., \& Wilner, S. J. (2010). Networked narratives: Understanding word-of-mouth marketing in online communities. Journal of marketing, 74(2), 71-89.

Kukla, M. (2012). SHARE IT ON FACEBOOK: EXAMINING VIRAL MARKETING AND MOTIVES TO PASS ALONG ELECTRONIC CONTENT ON SNS. Paper presented at the American Academy of Advertising. Conference. Proceedings (Online).

Kumar, V., Aksoy, L., Donkers, B., Venkatesan, R., Wiesel, T., \& Tillmanns, S. (2010). Undervalued or overvalued customers: capturing total customer engagement value. Journal of service research, 13(3), 297-310.

Laurent, G., \& Kapferer, J.-N. (1985). Measuring consumer involvement profiles. Journal of marketing research, 41-53.

Leeflang, P. (2011). Paving the way for "distinguished marketing". International Journal of Research in Marketing, 28(2), 76-88.

Liang, T.-P., \& Turban, E. (2011). Introduction to the special issue social commerce: a research framework for social commerce. International Journal of electronic commerce, 16(2), 5-14.

Lin, T. M., Lu, K.-Y., \& Wu, J.-J. (2012). The effects of visual information in eWOM communication. Journal of research in interactive marketing, 6(1), 7-26. 
Lipschultz, J. H. (2014). Social media communication: Concepts, practices, data, law and ethics: Routledge.

Lipsman, A., Mudd, G., Rich, M., \& Bruich, S. (2012). The power of "like": How brands reach (and influence) fans through social-media marketing. Journal of Advertising research, 52(1), 40-52.

Lu, H.-P., \& Yu-Jen Su, P. (2009). Factors affecting purchase intention on mobile shopping web sites. Internet Research, 19(4), 442-458.

Lueg, J. E., \& Finney, R. Z. (2007). Interpersonal communication in the consumer socialization process: scale development and validation. Journal of Marketing Theory and Practice, 15(1), 25-39.

Luo, X., Zhang, J., \& Duan, W. (2013). Social media and firm equity value. Information Systems Research, 24(1), 146-163.

MacKenzie, S. B., Lutz, R. J., \& Belch, G. E. (1986). The role of attitude toward the ad as a mediator of advertising effectiveness: A test of competing explanations. Journal of marketing research, 130143.

Madden, T. J., Ellen, P. S., \& Ajzen, I. (1992). A comparison of the theory of planned behavior and the theory of reasoned action. Personality and social psychology Bulletin, 18(1), 3-9.

Malhotra, N. K. (1988). Self concept and product choice: An integrated perspective. Journal of Economic Psychology, 9(1), 1-28.

Martin, C. L. (1998). Relationship marketing: a high-involvement product attribute approach. Journal of product \& brand management, $7(1), 6-26$.

McAlexander, J. H., Kim, S. K., \& Roberts, S. D. (2003). Loyalty: The influences of satisfaction and brand community integration. Journal of marketing Theory and Practice, 11(4), 1-11.

McAlexander, J. H., Schouten, J. W., \& Koenig, H. F. (2002). Building brand community. Journal of marketing, 66(1), 38-54.

McKenna, K. Y., \& Bargh, J. A. (2000). Plan 9 from cyberspace: The implications of the Internet for personality and social psychology. Personality and social psychology review, 4(1), 57-75.

Michaelidou, N., \& Dibb, S. (2006). Product involvement: an application in clothing. Journal of Consumer Behaviour, 5(5), 442-453.

Miniard, P. W., \& Cohen, J. B. (1983). Modeling personal and normative influences on behavior. Journal of Consumer Research, 10(2), 169-180.

Mittal, B., \& Lee, M.-S. (1989). A causal model of consumer involvement. Journal of economic psychology, 10(3), 363-389.

Mohr, I. (2013). The impact of social media on the fashion industry. Journal of Applied Business and Economics, 15(2), 17-22.

Mollen, A., \& Wilson, H. (2010). Engagement, telepresence and interactivity in online consumer experience: Reconciling scholastic and managerial perspectives. Journal of business research, 63(9-10), 919-925.

Moon, J., Chadee, D., \& Tikoo, S. (2008). Culture, product type, and price influences on consumer purchase intention to buy personalized products online. Journal of business research, 61(1), 3139.

Morris. (2017). Fashion, social media, and identity expression: an intersectional approach to understanding the fashion consumption patterns of black middle-class women. (Doctor of Philosophy), The University of Texas, The University of Texas at Austin. Retrieved from https://repositories.lib.utexas.edu/bitstream/handle/2152/47289/MORRIS-DISSERTATION2017.pdf?sequence $=1$

Mugge, R., Schifferstein, H. N., \& Schoormans, J. P. (2010). Product attachment and satisfaction: understanding consumers' post-purchase behavior. Journal of consumer Marketing, 27(3), 271282. 
Neuman, W. L., \& Kreuger, L. (2003). Social work research methods: Qualitative and quantitative approaches: Allyn and Bacon.

Njite, D., \& Parsa, H. (2005). Structural equation modeling of factors that influence consumer Internet purchase intentions of services. Journal of Services Research, 5(1).

O'Cass, A. (2004). Fashion clothing consumption: antecedents and consequences of fashion clothing involvement. European Journal of Marketing, 38(7), 869-882.

O'Cass, A., \& Choy, E. (2008). Studying Chinese generation Y consumers' involvement in fashion clothing and perceived brand status. Journal of Product \& Brand Management, 17(5), 341-352.

O'Cass, A., \& Lim, K. (2002). The influence of brand associations on brand preference and purchase intention: An Asian perspective on brand associations. Journal of International Consumer Marketing, 14(2-3), 41-71.

Olbrich, R., \& Holsing, C. (2011). Modeling consumer purchasing behavior in social shopping communities with clickstream data. International Journal of Electronic Commerce, 16(2), 15-40.

Oliver, R. L. (1980). A cognitive model of the antecedents and consequences of satisfaction decisions. Journal of marketing research, 460-469.

Onkvisit, S., \& Shaw, J. (1987). Self-concept and image congruence: Some research and managerial implications. Journal of Consumer Marketing, 4(1), 13-23.

O'Cass, A. (2000). An assessment of consumers product, purchase decision, advertising and consumption involvement in fashion clothing. Journal of Economic Psychology, 21(5), 545-576.

Park, Ciampaglia, G. L., \& Ferrara, E. (2016). Style in the age of instagram: Predicting success within the fashion industry using social media. Paper presented at the Proceedings of the 19th ACM Conference on Computer-Supported Cooperative Work \& Social Computing.

Park, J. O., Hwang, J. I., \& Park, E. M. (2011). The effect of fashion brand involvement and marketing communication means on building consumer-brand relationship. Paper presented the Advanced Materials Research.

Patterson, P., Yu, T., \& De Ruyter, K. (2006). Understanding customer engagement in services. Paper presented at the Advancing theory, maintaining relevance, proceedings of ANZMAC 2006 conference, Brisbane.

Pedeliento, G., Andreini, D., Bergamaschi, M., \& Salo, J. (2016). Brand and product attachment in an industrial context: The effects on brand loyalty. Industrial Marketing Management, 53, 194-206.

Perrin, A. (2015). Social media usage. Pew Research Center.

Peterson, R. A., Balasubramanian, S., \& Bronnenberg, B. J. (1997). Exploring the implications of the Internet for consumer marketing. Journal of the Academy of Marketing science, 25(4), 329-346.

PEW Research Center. (2018). Social Media Fact Sheet. Internet \& Technology Fact Sheet. Retrieved from https://www.pewinternet.org/fact-sheet/social-media/

Phau, I., \& Lo, C.-C. (2004). Profiling fashion innovators: A study of self-concept, impulse buying and Internet purchase intent. Journal of Fashion Marketing and Management: An International Journal, 8(4), 399-411.

Phelps, J. E., Lewis, R., Mobilio, L., Perry, D., \& Raman, N. (2004). Viral marketing or electronic word-ofmouth advertising: Examining consumer responses and motivations to pass along email. Journal of advertising research, 44(4), 333-348.

Phua, J., \& Kim, J. J. (2018). Starring in your own Snapchat advertisement: Influence of self-brand congruity, self-referencing and perceived humor on brand attitude and purchase intention of advertised brands. Telematics and Informatics, 35(5), 1524-1533.

Piacentini, M., \& Mailer, G. (2004). Symbolic consumption in teenagers' clothing choices. Journal of Consumer Behaviour: An International Research Review, 3(3), 251-262.

Powers, T. L., \& Hopkins, R. A. (2006). Altruism and consumer purchase behavior. Journal of International Consumer Marketing, 19(1), 107-130. 
Prendergast, G. P., Tsang, A. S., \& Chan, C. N. (2010). The interactive influence of country of origin of brand and product involvement on purchase intention. Journal of Consumer Marketing, 27(2), 180-188.

Price, L. L., Feick, L. F., \& Guskey, A. (1995). Everyday market helping behavior. Journal of Public Policy \& Marketing, 255-266.

Raacke, J., \& Bonds-Raacke, J. (2008). MySpace and Facebook: Applying the uses and gratifications theory to exploring friend-networking sites. Cyberpsychology \& behavior, 11(2), 169-174.

Rageh Ismail, A., \& Spinelli, G. (2012). Effects of brand love, personality and image on word of mouth: The case of fashion brands among young consumers. Journal of Fashion Marketing and Management: An International Journal, 16(4), 386-398.

Rahman. (2011). Understanding consumers' perceptions and buying behaviours: Implications for Denim Jeans Design. Journal of Textile and Apparel, Technology and Management, 7(1).

Rahman, \& Mannan. (2018). Consumer online purchase behavior of local fashion clothing brands: Information adoption, e-WOM, online brand familiarity and online brand experience. Journal of Fashion Marketing and Management: An International Journal, 22(3), 404-419. doi:10.1108/JFMM-11-2017-0118

Rahman, Saleem, Akhtar, Ali, \& Khan. (2014). Consumers' adoption of apparel fashion: The role of innovativeness, involvement, and social values. International Journal of Marketing Studies, 6(3), 49.

Ramayah, T., Ignatius, J., Leen, J. Y. A., \& Chiun, L. M. (2014). Discriminant analysis. Probability and Statistics: A Didactic Introduction, 384.

Rapp, J. (2016). Revolve CEO:'The Consumer Came to Us' in China's Fashion E-Commerce Market. Jing Daily.

Reinartz, W., Haenlein, M., \& Henseler, J. (2009). An empirical comparison of the efficacy of covariancebased and variance-based SEM. International Journal of research in Marketing, 26(4), 332-344.

Richins, M. L., \& Bloch, P. H. (1986). After the new wears off: The temporal context of product involvement. Journal of Consumer research, 13(2), 280-285.

Rigdon, E. E. (2012). Rethinking partial least squares path modeling: In praise of simple methods. Long Range Planning, 45(5-6), 341-358.

Rigdon, E. E. (2014). Rethinking partial least squares path modeling: breaking chains and forging ahead. Long Range Planning, 47(3), 161-167.

Ringle, C. M., Wende, S., \& Becker, J.-M. (2015). SmartPLS 3. Boenningstedt: SmartPLS GmbH, http://www. smartpls. com.

Ritchie, J., Lewis, J., Nicholls, C. M., \& Ormston, R. (2013). Qualitative research practice: A guide for social science students and researchers: sage.

Roblyer, M. D., McDaniel, M., Webb, M., Herman, J., \& Witty, J. V. (2010). Findings on Facebook in higher education: A comparison of college faculty and student uses and perceptions of social networking sites. The Internet and higher education, 13(3), 134-140.

Samala, N., \& Singh, S. (2018). Millennial's engagement with fashion brands: A moderated-mediation model of brand engagement with self-concept, involvement and knowledge. Journal of Fashion Marketing and Management: An International Journal.

Sarantakos, S. (2012). Social research: Macmillan International Higher Education.

Sarstedt, M. (2008). A review of recent approaches for capturing heterogeneity in partial least squares path modelling. Journal of Modelling in Management, 3(2), 140-161.

Sarstedt, M., \& Mooi, E. (2014). Cluster analysis. In A concise guide to market research (pp. 273-324): Springer.

Sarstedt, M., Ringle, C. M., Henseler, J., \& Hair, J. F. (2014). On the emancipation of PLS-SEM: A commentary on Rigdon (2012). Long range planning, 47(3), 154-160. 
Sashi, C. (2012). Customer engagement, buyer-seller relationships, and social media. Management decision, 50(2), 253-272.

Schenk, C. T., \& Holman, R. H. (1980). A sociological approach to brand choice: the concept of situational self image. ACR North American Advances.

Schiffman, L. G., \& Kanuk, L. L. (1997). Consumer behavior (6th ed.): Prentice Hall.

Schneier, M. (2014). Fashion in the Age of Instagram. The New York Times, 9.

Schulze, S. (2003). Views on the combination of quantitative and qualitative research approaches. Progressio, 25(2), 8-20.

Shankar, V., Smith, A. K., \& Rangaswamy, A. (2003). Customer satisfaction and loyalty in online and offline environments. International journal of research in marketing, 20(2), 153-175.

Shao, C. Y., Baker, J. A., \& Wagner, J. (2004). The effects of appropriateness of service contact personnel dress on customer expectations of service quality and purchase intention: The moderating influences of involvement and gender. Journal of Business Research, 57(10), 1164-1176.

Sherif, C. W., \& Sherif, M. (1967). Attitude, ego-involvement, and change: Wiley.

Sherman, S. J. (1980). On the self-erasing nature of errors of prediction. Journal of personality and Social Psychology, 39(2), 211.

Shifman, L. (2012). An anatomy of a YouTube meme. New media \& society, 14(2), 187-203.

Shocker, A. D., Srivastava, R. K., \& Ruekert, R. W. (1994). Challenges and opportunities facing brand management: An introduction to the special issue. Journal of marketing research, 31(2), 149158.

Shopify. (2018). Ecommerce Fashion Industry Statistics. Retrieved from https://www.shopify.com/enterprise/ecommerce-fashion-industry

Silva, T. H., Vaz de Melo, P. O., Almeida, J. M., Salles, J., \& Loureiro, A. A. (2013). A comparison of Foursquare and Instagram to the study of city dynamics and urban social behavior. Paper presented at the Proceedings of the 2nd ACM SIGKDD international workshop on urban computing.

Sirgy, M. J. (1982). Self-concept in consumer behavior: A critical review. Journal of consumer research, 9(3), 287-300.

SmartBrief. (2018). How Social Is Making It Easier For Brands To Sell. Shop.org SmartBrief. Retrieved from https://www.smartbrief.com/branded/72C24866-4250-4D70-96507F662457BBC0/B03CFD94-FE4A-448F-B03D-3707E7A60C6D

Smith, Coyle, J. R., Lightfoot, E., \& Scott, A. (2007). Reconsidering models of influence: the relationship between consumer social networks and word-of-mouth effectiveness. Journal of advertising research, 47(4), 387-397.

Smith, D., Hernández-García, Á., Agudo Peregrina, Á. F., \& Hair Jr, J. F. (2016). Social Network Marketing: A Segmentation Approach to Understanding Purchase Intention. Paper presented at the Proceedings of the 7th 2016 International Conference on Social Media \& Society.

Solomon, M. R. (1996). Consumer Behavior: Buying, having and being: Prentice-Hall international.

Spangenberg. (1997). Increasing health club attendance through self-prophecy. Marketing Letters, 8(1), 23-31.

Spangenberg, \& Greenwald. (1999). Social influence by requesting self-prophecy. Journal of Consumer Psychology, 8(1), 61-89.

Spangenberg, Sprott, Grohmann, \& Smith. (2003). Mass-communicated prediction requests: Practical application and a cognitive dissonance explanation for self-prophecy. Journal of Marketing, 67(3), 47-62.

Srinivasan, S., Rutz, O. J., \& Pauwels, K. (2016). Paths to and off purchase: quantifying the impact of traditional marketing and online consumer activity. Journal of the Academy of Marketing Science, 44(4), 440-453. 
Stephen, A. T., \& Galak, J. (2012). The effects of traditional and social earned media on sales: A study of a microlending marketplace. Journal of Marketing Research, 49(5), 624-639.

Stewart, D. W., \& Pavlou, P. A. (2002). From consumer response to active consumer: Measuring the effectiveness of interactive media. Journal of the Academy of Marketing Science, 30(4), 376-396.

Sundaram, D. S., Mitra, K., \& Webster, C. (1998). Word-of-mouth communications: A motivational analysis. ACR North American Advances.

Taylor, D. G., Lewin, J. E., \& Strutton, D. (2011). Friends, fans, and followers: do ads work on social networks?: how gender and age shape receptivity. Journal of advertising research, 51(1), 258275.

Thomas. (2019). Hudson Yards may be the moment of truth for how online brands compete in the real world. Retrieved from https://www.cnbc.com/2019/03/14/hudson-yards-may-be-a-moment-of-truth-for-onlinebrands-opening-stores.html

Thomson, Maclnnis, \& Park. (2005). The ties that bind: Measuring the strength of consumers' emotional attachments to brands. Journal of consumer psychology, 15(1), 77-91.

Tong, X., Su, J., \& Xu, Y. (2018). Brand personality and its impact on brand trust and brand commitment: an empirical study of luxury fashion brands. International journal of fashion design, technology and education, 11(2), 196-209.

Trusov, M., Bodapati, A. V., \& Bucklin, R. E. (2010). Determining influential users in internet social networks. Journal of Marketing Research, 47(4), 643-658.

Trusov, M., Bucklin, R. E., \& Pauwels, K. (2009). Effects of word-of-mouth versus traditional marketing: findings from an internet social networking site. Journal of marketing, 73(5), 90-102.

Tuli, F. (2010). The basis of distinction between qualitative and quantitative research in social science: Reflection on ontological, epistemological and methodological perspectives. Ethiopian Journal of Education and Sciences, 6(1).

Tuškej, U., Golob, U., \& Podnar, K. (2013). The role of consumer-brand identification in building brand relationships. Journal of business research, 66(1), 53-59.

Ulin, P. R., Robinson, E. T., \& Tolley, E. E. (2005). Qualitative methods in public health: a field guide for applied research. San Francisco, CA, 94103-91741.

Valenzuela, S., Park, N., \& Kee, K. F. (2009). Is there social capital in a social network site?: Facebook use and college students' life satisfaction, trust, and participation. Journal of Computer-Mediated Communication, 14(4), 875-901.

Vallerand, R. J. (1997). Toward a hierarchical model of intrinsic and extrinsic motivation. In Advances in experimental social psychology (Vol. 29, pp. 271-360): Elsevier.

van Doorn, J., Lemon, K. N., Mittal, V., Nass, S., Pick, D., Pirner, P., \& Verhoef, P. C. (2010). Customer Engagement Behavior: Theoretical Foundations and Research Directions. Journal of Service Research, 13(3), 253-266. doi:10.1177/1094670510375599

Vivek, S. D., Beatty, S. E., \& Morgan, R. M. (2012). Customer engagement: Exploring customer relationships beyond purchase. Journal of marketing theory and practice, 20(2), 122-146.

Wang, X., Yu, C., \& Wei, Y. (2012). Social media peer communication and impacts on purchase intentions: A consumer socialization framework. Journal of interactive marketing, 26(4), 198208.

Warrington, P., \& Shim, S. (2000). An empirical investigation of the relationship between product involvement and brand commitment. Psychology and Marketing, 17(9), 761-782.

Watson, S. (2016). What is Happening to Commercial Malls: Evaluating Contradicting Opinions.

Wells, J. D., Valacich, J. S., \& Hess, T. J. (2011). What signal are you sending? How website quality influences perceptions of product quality and purchase intentions. MIS quarterly, 373-396.

Wen, C., Prybutok, V. R., \& Xu, C. (2011). An integrated model for customer online repurchase intention. Journal of Computer Information Systems, 52(1), 14-23. 
Westbrook, R. A. (1987). Product/consumption-based affective responses and postpurchase processes. Journal of marketing research, 258-270.

Wirtz, J., Den Ambtman, A., Bloemer, J., Horváth, C., Ramaseshan, B., Van De Klundert, J., . . . Kandampully, J. (2013). Managing brands and customer engagement in online brand communities. Journal of service Management, 24(3), 223-244.

Wolny, J., \& Mueller, C. (2013). Analysis of fashion consumers' motives to engage in electronic word-ofmouth communication through social media platforms. Journal of Marketing Management, 29(5-6), 562.

Xie, K., \& Lee, Y.-J. (2015). Social media and brand purchase: Quantifying the effects of exposures to earned and owned social media activities in a two-stage decision making model. Journal of Management Information Systems, 32(2), 204-238.

Yoo, B., \& Donthu, N. (2001). Developing and validating a multidimensional consumer-based brand equity scale. Journal of business research, 52(1), 1-14.

Zaichkowsky. (1985). Measuring the involvement construct. Journal of consumer research, 12(3), 341352.

Zhang, B., \& Kim, J.-H. (2013). Luxury fashion consumption in China: Factors affecting attitude and purchase intent. Journal of Retailing and Consumer Services, 20(1), 68-79. 